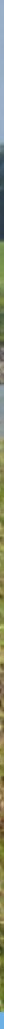

\title{
Kansen voor ontwikkeling van robuuste natuur in Nederland
}

M.E. Sanders, R.J.H.G Henkens, J.A. Veraart, I. Woltjer, J.G.M. van der Greft-van Rossum en J. Clement 



\section{Kansen voor ontwikkeling van robuuste natuur in Nederland}

M.E. Sanders, R.J.H.G Henkens, J.A. Veraart, I. Woltjer, J.G.M. van der Greft-van Rossum en J. Clement

Dit onderzoek is uitgevoerd door Alterra Wageningen UR in opdracht van en gefinancierd door het ministerie van Economische Zaken, in het kader van het Beleidsondersteunend onderzoekthema 'Zorgplicht Veerkrachtige Natuur - Biodiversiteit terrestrisch' (projectnummer BO-11-019.01-009).

Wageningen Environmental Research

Wageningen, september 2016

Rapport 2748

ISSN 1566-7197 
Sanders, M.E., R.J.H.G Henkens, J.A. Veraart, I. Woltjer, J.G.M. van der Greft-van Rossum, J. Clement, 2016. Kansen voor ontwikkeling van robuuste natuur in Nederland. Wageningen, Wageningen Environmental Research, Rapport 2748. 70 blz.; 14 fig.; 9 tab.; 46 ref.

Het kabinet wil een robuuste en veelzijdige natuur die de invloed van de samenleving kan verdragen. Deze natuur moet passen bij het veranderende klimaat, maximaal aansluiten bij natuurlijke processen, duurzaam en betaalbaar zijn, een toekomstbestendig beheer en haalbare doelen hebben. Robuuste natuur kan dus tegen een stootje en heeft een nuttige functie.

Maar wat verstaan we nu onder robuuste, toekomstbestendige, veelzijdige, zelfredzame, veerkrachtige natuur? Dit rapport heeft als doel om de bovenstaande ideeën uit de natuurvisie te concretiseren. Daarvoor zoeken we naar kansrijke locaties voor robuuste natuur met o.a. meer mogelijkheden voor natuurlijke processen en naar een combinatie van natuur met maatschappelijke opgaven.

The government wants a robust and versatile nature that can endure the influence of society. This nature should be adapted to the changing climate, release natural processes as much as possible, consist of sustainable and affordable management, and contain achievable goals. Hence, robust and versatile nature can resist human disturbance and fulfil many ecosystem services. But what is robust, future-proof, versatile, self-reliant, resilient nature exactly? This report aims to clarify the above ideas presented in the Dutch nature vision. To do so, we search for criteria and promising locations to develop robust nature.

Trefwoorden: robuuste natuur, natuurlijke processen, ecosysteemdiensten, natuurontwikkeling

Dit rapport is gratis te downloaden van http://dx.doi.org/10.18174/391877 of op

www.wur.nl/environmental-research (ga naar 'Wageningen Environmental Research' in de grijze balk onderaan). Wageningen Environmental Research verstrekt geen gedrukte exemplaren van rapporten.

(9) 2016 Wageningen Environmental Research (instituut binnen de rechtspersoon Stichting Wageningen Research), Postbus 47, 6700 AA Wageningen, T 03174807 00, E info.alterra@wur.nl, www.wur.nl/environmental-research. Wageningen Environmental Research is onderdeel van Wageningen University \& Research.

- Overname, verveelvoudiging of openbaarmaking van deze uitgave is toegestaan mits met duidelijke bronvermelding.

- Overname, verveelvoudiging of openbaarmaking is niet toegestaan voor commerciële doeleinden en/of geldelijk gewin.

- Overname, verveelvoudiging of openbaarmaking is niet toegestaan voor die gedeelten van deze uitgave waarvan duidelijk is dat de auteursrechten liggen bij derden en/of zijn voorbehouden.

Wageningen Environmental Research aanvaardt geen aansprakelijkheid voor eventuele schade voortvloeiend uit het gebruik van de resultaten van dit onderzoek of de toepassing van de adviezen.

Wageningen Environmental Research Rapport 2748 | ISSN 1566-7197

Foto omslag: Marlies Sanders 


\section{Inhoud}

$\begin{array}{ll}\text { Woord vooraf } & 5\end{array}$

$\begin{array}{ll}\text { Samenvatting } & 7\end{array}$

$1 \quad$ Inleiding $\quad 9$

1.1 Kader en aanleiding: de Rijksnatuurvisie 2014

1.2 Algemene vraagstelling en afbakening van projecten 10

1.3 Definities van begrippen 11

1.4 Hoe gaan beleid en beheer met deze begrippen om? 13

$\begin{array}{ll}\text { Project robuuste natuur: onderzoeksvragen en methode } & 16\end{array}$

$\begin{array}{lll}2.1 & \text { Onderzoeksvragen } & 16\end{array}$

2.2 Methode 16

2.2.1 Best practices 17

2.2.2 Vraag naar ecosysteemdiensten 17

$\begin{array}{ll}2.2 .3 \text { Water als leidend principe } & 18\end{array}$

2.2.4 Van criteria naar kansrijkdom voor robuuste natuur $\quad 19$

2.2.5 Weging van belangen $\quad 20$

3.1 Criteria op basis van de gekozen gebieden $\quad 21$

3.2 Keerzijde van robuuste natuur $\quad 25$

$4 \quad$ Veelzijdige natuur midden in de samenleving $\quad 28$

4.1 Levering van diensten door ecosystemen 28

4.2 Maatschappelijke vraag naar ecosysteemdiensten 29

4.3 Zoekgebieden voor robuuste naturontwikkeling op basis van ecosysteemdiensten

5.1 Landelijke kaarten met criteria voor succesvolle robuuste natuur 32

5.2 Kaart met kansen voor ontwikkeling van robuuste natuur 34

$\begin{array}{lll}5.3 & \text { Weging van belangen } & 37\end{array}$

5.3.1 Meekoppelen met Klimaat, ecosysteemdiensten en natuurlijke processen 37

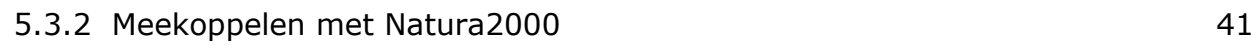

$6 \quad$ Discussie en conclusies $\quad 42$

6.1 Geen vaste definitie voor robuuste natuur $\quad 42$

6.2 Een robuuste methode voor kansrijke locaties $\quad 43$

6.3 Robuuste natuur uit Natuurvisie is kansrijk, mits... 44

$\begin{array}{lll}6.4 & \text { Kansrijke gebieden voor robuuste natuur } & 47\end{array}$

6.5 Gebruiksmogelijkheden kansrijkdomkaarten 48

$\begin{array}{ll}\text { Literatuur } & 49\end{array}$

$\begin{array}{lll}\text { Bijlage } 1 \text { Beschrijving best practices } & 51\end{array}$

$\begin{array}{lll}\text { Bijlage } 2 & \text { Bronnen kaartgegevens } & 68\end{array}$ 



\section{Woord vooraf}

De Rijksnatuurvisie 2014 'Natuurlijk verder' presenteert in grote lijnen de wijze waarop het kabinet vorm wil geven aan robuuste en veelzijdige natuur. Voor de nadere uitwerking van deze natuur zijn in 2015 twee parallelle projecten gestart:

- Kansen voor robuuste natuur in Nederland.

- Kansen voor meer natuurlijkheid in Natura 2000-gebieden (Bijlsma et al., 2016).

Dit rapport betreft het eerste project. In de inleiding wordt nader ingegaan op de afbakening van beide projecten.

Voor beide projecten was een begeleidingscommissie ingesteld met vertegenwoordigers van het ministerie, BIJ12 en provincies:

- Ministerie van EZ: J.J.M. van den Heuvel, G.S.M. Veltmeijer-Van Schijndel, G.T.M. Grimberg.

- BIJ12: A.G.G. Heeren.

- Provincies: M. Groeneweg (Fryslân), H. van Maar (Noord-Brabant).

De auteurs bedanken Dick Melman en Friso van der Zee voor hun waardevolle commentaar. 


\section{Samenvatting}

Het kabinet wil een robuuste en veelzijdige natuur die de invloed van de samenleving kan verdragen. Deze natuur moet passen bij het veranderende klimaat, maximaal aansluiten bij natuurlijke processen, duurzaam en betaalbaar zijn, een toekomstbestendig beheer en haalbare doelen hebben. Robuuste natuur kan dus tegen een stootje en heeft een nuttige functie.

Maar wat verstaan we nu onder robuuste, toekomstbestendige, veelzijdige, zelfredzame, veerkrachtige natuur? Dit rapport heeft als doel om de bovenstaande ideeën uit de natuurvisie te concretiseren. Daarvoor zoeken we naar meer mogelijkheden voor natuurlijke processen en naar een combinatie van robuuste natuur met maatschappelijke opgaven. Zijn er in Nederland kansen voor robuuste natuur of is het idee te mooi om waar te zijn?

De onderzoeksvragen zijn:

- Wat verstaat men onder robuuste natuur en hoe gaat men daarmee om?

- Wat zijn criteria voor succesvolle robuuste natuur en wat zijn mogelijke consequenties?

- Wat zijn de mogelijkheden voor meer natuurlijke processen buiten de kaders van Natura 2000?

- Wat zijn mogelijke maatschappelijke opgaven en wat zijn daarbij de kansen (vrijheidsgraden) voor robuuste natuur?

- Hoe kunnen de criteria worden gewogen en kunnen daarmee kansrijke gebieden op de kaart worden onderscheiden?

Voor beide projecten is het gebruik van een aantal veelvoorkomende termen afgestemd. Hierbij hebben de omschrijvingen in de Van Dale als uitgangspunt gediend. Robuust betekent 'sterk, stevig gebouwd'. Robuuste natuur kan invloeden en fluctuaties in haar omgeving doorstaan of overleven en zal door verstoringen en medegebruik op gebiedsniveau niet wezenlijk veranderen. Dit begrip onderscheiden we van veerkrachtige natuur die 'soepel, lenig' is en mogelijkheden heeft zich te herstellen. Terwijl robuuste natuur een verstoring (zoals overstroming of zware betreding) doorstaat, zal veerkrachtige natuur mogelijk verdwijnen maar zich vervolgens herstellen, bijvoorbeeld door hervestiging vanuit andere gebieden. Als natuur onvoldoende robuust of veerkrachtig is, is deze kwetsbaar voor verstoringen en voor medegebruik.

De criteria die robuuste natuur kenmerken en de duiding van deze kenmerken zijn bepaald uitgaande van goede voorbeeldgebieden (best practices) en met maatschappelijke opgaven samenhangende ecosysteemdiensten. Bij de criteria zijn landelijke kaarten gezocht. Die kaarten zijn in GIS gecombineerd (gewogen) tot kansenkaarten. Voor de gebiedsafbakening is water als leidend principe gebruikt; eenheden van de kansenkaart zijn watersysteemeenheden.

\section{Hoofdconclusies}

Onder robuuste natuur verstaat de Rijksnatuurvisie veerkrachtige, toekomstbestendige natuur met lage beheerlasten en haalbare doelen, die maximaal aansluit bij natuurlijke processen, die op natuurlijke wijze kan meebewegen met veranderende omstandigheden zoals door het klimaat en die de invloed van de samenleving kan verdragen en daar bij kan gedijen.

Robuuste natuur kan als categorie worden gepositioneerd tussen grootschalige, half-natuurlijke en multifunctionele natuur in. Ten opzichte van grootschalige dynamische natuur of wildernisnatuur is robuuste natuur veel minder gevoelig voor menselijk medegebruik. Ten opzichte van half-natuurlijke natuur wordt er minder intensief beheerd voor behoud van biodiversiteit of cultuurhistorie. Ten opzichte van multifunctionele natuur wordt er meer gebruikgemaakt van natuurlijke processen, in het bijzonder landschapsvormende processen onder invloed van overstromingen en grondwaterdynamiek. 
Robuuste natuur is kansrijk mits:

1. Er mogelijkheden zijn voor landschapsvormende processen en natuurlijke (hydrologische) processen. Vooral in het kustgebied en in het rivierengebied heeft het stromend water voldoende kracht voor erosie- en sedimentatieprocessen. De invloed van deze processen is meestal door menselijke invloed (waterkeringen e.d.) ingeperkt, maar de best practices laten zien dat er potentie is om deze processen meer ruimte te geven. In bijna alle gebieden is meer ruimte voor biotische processen, zoals een natuurlijkere populatiedynamiek van grote zoogdieren, het laten liggen van kadavers en dood hout e.d.

2. Er lage beheerlasten kunnen worden gerealiseerd. De beheertypen van de Index-NL en daarmee ook de jaarvergoeding behorende bij de Subsidieverordening natuur- en landschapsbeheer zijn echter nog niet specifiek gericht op robuuste natuur. Alleen bij grootschalige natuur is er sprake van lagere beheerlasten. Extra kosten voor aanvullende maatregelen of schade (aan gewassen en onroerend goed) kunnen de gewenste lage beheerlasten en dus de kansrijkdom (deels) tenietdoen.

3. Er een vraag ecosysteemdiensten is. Kansen voor ontwikkeling van robuuste natuur te midden van de samenleving nemen toe naarmate er mogelijkheden zijn om synergie met ecosysteemdiensten en met maatschappelijke opgaven te realiseren. De meeste best practices verlenen diensten die te maken hebben met waterveiligheid en wateropvang. In de zoektocht naar mogelijke locaties voor robuuste natuur is het daarom van belang om aan te sluiten bij de maatschappelijke vraag naar dit soort ecosysteemdiensten of naar een stapeling van ecosysteemdiensten.

4. De doelen goed haalbaar zijn. Er kan veel biodiversiteitswinst worden behaald bij bijvoorbeeld uitgangssituaties met nauwelijks natuurwaarden, zoals kale bodem, landbouw of bomenakkers. De best practices laten zien dat er in 'nieuwe' natuurgebieden zeldzame soorten kunnen profiteren en dat ook bij de heersende milieucondities natuurwinst valt te halen.

5. Er kan worden meebewogen met klimaatverandering. Reliëf en daarmee samenhangende gradiënten of landschappelijke heterogeniteit bieden lokaal uitwijkmogelijkheden voor soorten. Reliëf, klimaatcorridors en het natuurnetwerk bieden migratiemogelijkheden voor soorten.

Door de brede basis van verschillende best practice-gebieden en de verdeling van de criteria over de kenmerken van robuuste natuur uit de natuurvisie, is een robuuste set aan criteria gevonden om de kansrijkdomkaarten te berekenen. De kansrijkdomkaarten laten zien dat er vooral kansen zijn voor robuuste klimaatbestendige natuur, maar ook op locaties met vraag naar ecosysteemdiensten en potentie voor natuurlijke processen zoals langs de grote rivieren, in beekdalsystemen, MiddenDrenthe, in de Gelderse vallei en enkele watersysteemeenheden van de Friese boezem. Ook bij een andere prioritering van de criteria zijn het veelal dezelfde gebieden die kansrijk zijn. Alleen robuuste natuur met een landbouwfunctie en van de grote wateren blijven onderbelicht vanwege de gebiedskeuze. Niet alleen in agrarische gebieden, maar ook in de stad kan er robuuste natuur worden gerealiseerd ongeacht ambitie en schaal. In deze gebieden kunnen robuuste natuur en meer natuurlijke processen een belangrijke bijdrage leveren aan het verbeteren van ecosysteemdiensten en aan de lokale biodiversiteit. Ambitie en schaal bepalen echter wel de mate waarin robuuste natuur bijdraagt aan de landelijke en internationale natuurdoelen.

De kansrijkdomkaarten zijn bedoeld om de discussie te faciliteren over de mogelijkheden van robuuste natuur in zowel de provincie als tussen rijk en provincie. Daarbij gaat het over bijvoorbeeld welke criteria prioriteit hebben en in welke gebieden de meeste mogelijkheden zijn voor de ontwikkeling van robuuste(re) natuur. 


\section{$1 \quad$ Inleiding}

\section{$1.1 \quad$ Kader en aanleiding: de Rijksnatuurvisie 2014}

De Rijksnatuurvisie 2014 'Natuurlijk verder' presenteert in grote lijnen de wijze waarop het kabinet in de komende vijftien tot twintig jaar samen met de provincies vorm wil geven aan het publieke belang van toekomstbestendige natuur (EZ, 2014a). De afgelopen decennia hebben investeringen in de natuur en biodiversiteit tot mooie resultaten geleid, maar die hebben de achteruitgang van veel soorten en habitats nog niet kunnen stoppen. De natuurvisie 'maakt duidelijk wat nodig is om nationale en internationale doelen te realiseren waar we al veel in geïnvesteerd hebben: behoud van biodiversiteit en een sterkere en duurzame betekenis van natuur voor de samenleving en economie'. Hiertoe is een nieuw natuurbouwwerk nodig 'waarvan de bouwstenen door verschillende partijen worden aangeleverd: burgers, ondernemers, maatschappelijke organisaties en overheden'.

Vanuit de vraag 'Waar doen we het ook alweer voor?' bepleit het kabinet de volgende accentverschuivingen:

- 'Er wordt op een hoger schaalniveau gestuurd op het bereiken van Natura 2000-doelen. Verwacht mag worden dat sturen alleen op de schaal van het beschermde gebied minder natuur oplevert tegen hogere inspanningen dan wanneer dat op een hoger, bijvoorbeeld regionaal schaalniveau gebeurt. Ook ligt winst in het verschiet wanneer de te bereiken doelen worden bepaald voor biogeografische regio's in plaats van voor individuele lidstaten';

- 'Veranderingen van klimaat en samenleving doen steeds meer behoefte ontstaan aan sturen op condities voor natuurlijke processen in plaats van sturen op specifieke soorten en habitats. Tot die omstandigheden behoren de kwaliteiten van het bodemsysteem en de aanwezigheid van natuurlijke plaagbestrijders in landschapselementen, mogelijk in combinatie met maatschappelijke diensten zoals waterberging'.

In de natuurvisie wordt het nieuwe natuurbouwwerk sterk geassocieerd met robuuste, veerkrachtige en toekomstbestendige natuur, natuurlijke processen en een landschappelijke schaalniveau. Deze aspecten worden op verschillende plaatsen in de visie nader toegelicht en uitgewerkt tot het beleidsdoel 'Toekomstbestendige natuur: meer ruimte voor natuurlijke processen':

'Naast sturen op soorten en habitats op specifieke plekken, zal een zwaarder accent komen te liggen op het creëren van ruimte voor natuurlijke processen in de dynamische delta die aan de Nederlandse natuur mede zijn unieke karakter geeft. Daardoor kunnen robuuste systemen ontstaan: lage beheerlasten en haalbare doelen die op natuurlijke wijze mee kunnen bewegen met veranderende omstandigheden, zoals door het klimaat'.

Robuuste, veerkrachtige en veelzijdige natuur, die de invloed van de samenleving niet alleen kan verdragen maar daar juist ook bij kan gedijen en kan worden benut, vergt volgens het kabinet in sommige gevallen een flexibelere aanpak bij het behalen van de doelen van EU-richtlijnen. De natuurvisie signaleert dat 'wetten en regels in de huidige toepassing te veel een doel op zich lijken te zijn geworden'.

Ook in het Natuurpact (EL\&I, 2013) wordt het woord robuust gebruikt: 'Het Natuurnetwerk Nederland is de ruggengraat van de natuur in Nederland. Die ruggengraat moet robuust zijn, tegen een stootje kunnen'. Provincies maken het natuurnetwerk robuuster door gebieden te vergroten met nieuwe natuur, maar ook door de condities te verbeteren en verbindingen te realiseren tussen natuurgebieden onderling en tussen natuurgebieden en hun omgeving. In het Natuurpact worden natuurlijke processen en dynamiek niet genoemd.

Een robuuste en toekomstbestendige natuur in de grote wateren van Nederland, dat is het doel van de 'Natuurambitie Grote Wateren 2050 en verder' (EZ, 2014b). Volgens de Natuurambitie is dit: 'natuur die tegen een stootje kan, waar we van kunnen genieten, en die goed samen gaat met veiligheid, 
economie, energie en welzijn'. De natuurambitie schetst een toekomstbeeld van zes verschillende grote wateren met en zonder natuurambitie en beschrijft kort de kansen en keuzen die gemaakt moeten worden voor deze ambitie. In dit toekomstbeeld zijn de natuurlijke processen in de grote wateren zo veel mogelijk hersteld en kunnen de veerkrachtige ecosystemen zich aanpassen aan een veranderend klimaat.

\subsection{Algemene vraagstelling en afbakening van projecten}

Het beleidsdoel toekomstbestendige robuuste natuur vereist nadere uitwerking. Hierom is door het ministerie van EZ gevraagd kansen voor robuuste natuur en natuurlijke processen in kaart te brengen zowel in relatie tot Natura 2000 -doelen als tot andere gebruiksfuncties.

Deze vraagstelling is verdeeld over twee projecten:

\section{- Kansen voor ontwikkeling van robuuste natuur in Nederland}

Dit project betreft het opstellen en verkennen van criteria voor robuuste natuur en het verkennen van de mogelijkheden voor robuuste, toekomstbestendige natuur met meer ruimte voor natuurlijke processen in Nederland, vooral in combinatie met maatschappelijke opgaven en gebruiksfuncties.

\section{- Kansen voor meer natuurlijkheid in Natura 2000-gebieden}

Dit project richt zich op Natura 2000-gebieden en directe omgeving en verkent hoe gebiedsdoelen zodanig kunnen worden geprioriteerd en beoordeeld dat meer ruimte ontstaat voor de werking van natuurlijke processen. Tegelijkertijd moeten doelen voor behoud en ontwikkeling op langere termijn effectief en efficiënt gerealiseerd kunnen worden, waar mogelijk in combinatie met andere gebruiksfuncties.

Hoe de projecten zich verhouden tot elkaar is weergegeven in Figuur 1.1.

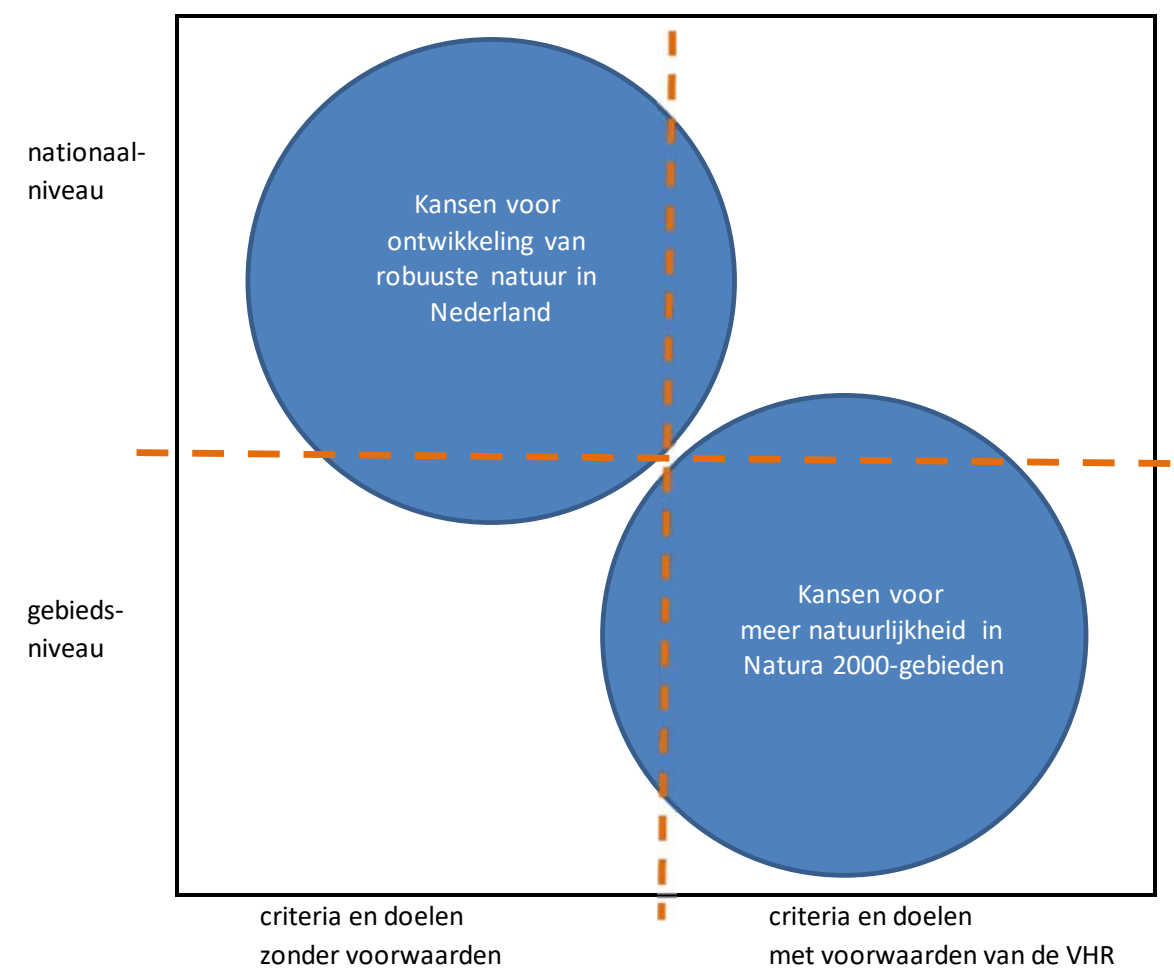

Figuur 1.1 Schematische weergave van verschillen en samenhang van beide project Robuuste Natuur. Zie tekst voor toelichting. 
De twee projecten verschillen in schaalniveau en in vrijheidsgraden voor het bepalen van criteria, richtlijnen en doelen:

- In het project 'Kansen voor robuuste natuur in Nederland' wordt de kansrijkdom bepaald door middel van criteria waarvan de gegevens landelijk beschikbaar zijn. Gegevens van gebieden worden alleen gebruikt om criteria te selecteren en vervolgens toe te passen op nationaal niveau. Er wordt onbelemmerd gezocht naar allerlei criteria, maar ook naar mogelijke natuurdoelen. Immers ook voor ontwikkeling van robuuste natuur moeten passende doelen kunnen worden geformuleerd.

- Het project 'Kansen voor meer natuurlijkheid in Natura 2000-gebieden' richt zich op ruimte voor meer natuurlijkheid binnen of rond Natura 2000-gebieden waarbij de Vogel- en Habitatrichtlijn belangrijke voorwaarden opleggen bij het zoeken naar ruimte in de doelformulering. Echter, ook niet-Natura 2000-doelen worden expliciet betrokken.

De projecten vullen elkaar aan in de zoektocht naar robuuste natuur. De in het eerste project gevonden kansrijke gebieden voor ontwikkeling van robuuste natuur in Nederland is een eerste stap. Vervolgens moet een gebied onderzocht worden op gebiedsspecifieke kenmerken en doelen, zoals in het tweede project is gebeurd door middel van een landschapsecologische analyse, voordat er tot het nemen van maatregelen kan worden overgegaan.

De resultaten van het onderzoek naar kansen voor robuuste natuur in Nederland zijn gepubliceerd in voorliggend rapport. De nadere invulling van het begrip natuurlijkheid en resultaten van kansen voor meer natuurlijkheid in Natura 2000-gebieden zijn gepubliceerd in Bijlsma et al. (2016). Van belang voor beide projecten is echter te weten wat we verstaan onder robuuste natuur, natuurlijkheid en natuurlijke processen en hoe men daarmee omgaat. Daarom is eerst onderzocht hoe relevante begrippen uit de Rijksnatuurvisie concreter uitgewerkt kunnen worden in beide projecten. Hierbij zijn we uitgegaan van gemeenschappelijke definities van begrippen op hoofdlijnen zoals toegelicht in paragraaf 1.3. De inleiding tot en met paragraaf 1.3 zijn daarom voor beide rapporten grotendeels identiek. Vervolgens wordt in beide rapporten afzonderlijk nader toegelicht hoe beleid en beheer met deze begrippen omgaan en worden concrete criteria uitgewerkt voor robuuste natuur en natuurlijkheid. Hoe men in beleid en beheer ermee omgaat is in dit rapport toegelicht in paragraaf 1.4.

\subsection{Definities van begrippen}

Het definiëren van begrippen voorkomt verwarring en maakt discussies scherper. Een te strakke toepassing van definities wordt echter dogmatisch en kan polariserend en contraproductief werken. In deze paragraaf bakenen we enkele belangrijke termen uit de Rijksnatuurvisie en ander rijksbeleid in grote lijnen af (Tabel 1.1). In beide projecten worden concrete criteria uitgewerkt voor robuuste natuur en natuurlijkheid.

Tabel 1.1 Vergelijkbare termen in de Rijksnatuurvisie en andere relevante beleidsdocumenten.

\begin{tabular}{|l|l|}
\hline Termen & Bron \\
\hline $\begin{array}{l}\text { Half-natuurlijke, nagenoeg-natuurlijke, begeleid- } \\
\text { natuurlijke, multifunctionele natuur }\end{array}$ & $\begin{array}{l}\text { Natuurbeleidsplan 1990, Handboek } \\
\text { natuurdoeltypen 1995, 2001 }\end{array}$ \\
\hline Grootschalige dynamische natuur & Index Natuur \& Landschap 2013 \\
\hline Natuurlijke processen, natuurlijke dynamiek & $\begin{array}{l}\text { Rijksnatuurvisie 2014, Natuurambititie } \\
\text { Grote Wateren 2014 }\end{array}$ \\
\hline $\begin{array}{l}\text { Eigenschappen van natuur: robuust, veerkrachtig, } \\
\text { toekomstbestendig, duurzaam, veelzijdig }\end{array}$ & $\begin{array}{l}\text { Rijksnatuurvisie 2014, Natuurambititie } \\
\text { Grote Wateren 2014 }\end{array}$ \\
\hline
\end{tabular}




\section{Natuur en natuurlijk}

Natuur is 'dat wat de mens om zich heen ziet als niet door hem gewijzigd' (www.vandale.nl). Uit deze omschrijving vloeit voort dat natuur heel verschillend kan worden gezien en ervaren. Natuurlijk is 'op de natuur betrekking hebbend', 'door de natuur gevormd' of 'naar of volgens de natuur' (www.vandale.nl).

Er wordt verschillend gedacht over wat wel of geen natuur is. Vaak worden de spontane vestiging en zelfordening van planten- en diersoorten als scheidend criterium genomen. Een ingezaaid grasland is dan geen natuur, maar de spontane vestiging van soorten ('onkruid') in akkers wel. Uitgestrekte heidevelden, bijv. op de Veluwe, zijn het resultaat van historisch landgebruik, maar de planten- en diersoorten van de heide hebben zich er zonder directe sturing door de mens gevestigd en uitgebreid. Een heide blijft echter in veel gevallen geen heide als de mens niet op een zeker moment ingrijpt en daarmee ontwikkeling naar bos tegengaat. Daarom wordt de term 'half-natuurlijk' gebruikt voor natuur waarbij de mens de spontane ontwikkeling beïnvloedt door op zijn tijd in te grijpen door bijvoorbeeld te maaien of te plaggen of opslag te verwijderen. Deze beïnvloeding kan variëren in frequentie en intensiteit. Als er sprake is van een compromis met andere functies, zoals agrarische productie, commerciële bosbouw of intensieve recreatie, dan wordt de term 'multifunctionele natuur' gebruikt.

Een belangrijk aspect van de definitie van natuur is dat ook terreinvormen, grondsoorten en wateren onderdeel zijn van natuur zolang de mens die ziet als niet door hem gewijzigd. Niet door de mens gewijzigde terreinen worden ook wel wildernis genoemd. Wildernis is een 'een woeste streek waar de natuur vrij spel heeft' (www.vandale.nl). Volgens de Wilderness Act uit 1964 in de USA: 'an area where the earth and its community of life are untrammeled by man, where man himself is a visitor who does not remain'. De Europese Commissie (EC, 2013) hanteert de volgende definitie: 'an area governed by natural processes. It is composed of native habitats and species, and large enough for the effective ecological functioning of natural processes. It is unmodified or only slightly modified and without intrusive or extractive human activity, settlements, infrastructure or visual disturbance'. Wildernis volgens deze definities komt in Nederland niet voor (zie ook Kwak \& Kuiters, 2014). (Nieuwe) wildernis in Nederland omvat grootschalige gebieden waar spontane natuurontwikkeling plaatsvindt, in veel gevallen met inzet van grote grazers. Echter ook menselijke ervaring en beleving maken een gebied tot nieuwe wildernis; zie Roos et al. (2014) voor een scala aan visies op wildernis. De ideeën achter deze definities, natuur zonder menselijke invloed en variatie door natuurlijke processen, zijn in het Nederlandse beleid uitgewerkt in de beheerstrategieën nagenoeg- en begeleid natuurlijk (Bal et al., 2001) en recentelijk in de term grootschalige dynamische natuur.

\section{Grootschalige dynamische natuur}

In de Index Natuur \& Landschap (Schipper \& Siebel, 2013) wordt grootschalige dynamische natuur beschreven als 'een natuurtype waar natuurlijke processen een bepalende invloed hebben op het landschap. Als gevolg hiervan zijn jonge (pionier) successiestadia zoals open grond, open water of grasland aanwezig, maar ook oude successiestadia zoals bossen of venen. Er is daarom sprake van een ruime variatie in levensgemeenschappen en soorten.' Grootschalige, dynamische natuur is aanwezig als er weinig of geen menselijke invloed is op het landschap. Die omstandigheden zijn op de meeste plaatsen in Nederland al lang verdwenen. Bij ontwikkeling van grootschalig dynamische natuur valt vaak niet te reconstrueren hoe de natuurlijke referenties eruitzien en kan men besluiten om gewenste ruimtelijke variatie te bereiken door de landschapsvormende processen af en toe een handje te helpen.

\section{Natuurlijke processen}

Proces betekent 'verloop of ontwikkelingsgang' (www.vandale .nl). Natuurlijke processen zijn dus logischerwijs processen die op natuur betrekking hebben, door de natuur worden gevormd of verlopen naar of volgens de natuur (zie Natuur en natuurlijk). Natuurlijke processen spelen op elke schaal en in elk onderdeel van de biosfeer (Figuur 1.2) en beïnvloeden elkaar. Zo kan de herintroductie van de wolf een keten van processen op gang brengen die het landschap uiteindelijk doen veranderen. 
Figuur 1.2 Voorbeelden van natuurlijke processen op verschillende schaalniveaus.

Het Nederlandse landschap is gevormd door glaciale (aan landijs of gletsjers gerelateerde), mariene (aan zee-invloed relateerde), fluviatiele (aan rivier- en beekinvloed gerelateerde) en eolische (aan windinvloed gerelateerde) processen en door de menselijke invloeden daarop. Deze zogenaamde landschapsvormende processen hebben de opbouw en het reliëf van het landschap bepaald en doen dat bijv. in het kustgebied nog steeds. In minder dynamische perioden en delen van het landschap waren en zijn bodemvorming, veenvorming en vegetatiesuccessie belangrijke natuurlijke processen. Op een lager schaalniveau zijn hoogteverschillen (reliëf), water, bodem en graasdruk sturend voor het voorkomen van soorten. Reliëf zorgt voor stroming in grond- en oppervlaktewater en gradiënten in milieucondities zoals overgangen van nat naar droog, voedselrijk naar voedselarm, basenrijk naar zuur en van zoet naar zout. De menselijke invloed op het reliëf, de natuurlijke processen en het voorkomen van soorten is al eeuwen groot, maar werkt sinds de landbouwintensiveringen nivellerend en verstorend. Veel soorten zijn in veel gebieden verdwenen door ontginning, verdroging, vermesting en verzuring en staan in toenemende mate onder druk door klimaatverandering. Dergelijke gradiënten in milieucondities zijn daarom uitermate belangrijk voor het overleven van soorten (uitwijkmogelijkheden, risicospreiding).

\section{Robuust, veerkrachtig en kwetsbaar}

Robuust betekent 'sterk, stevig gebouwd' of 'flink, krachtdadig' (www.vandale.nl). Robuuste natuur kan invloeden (verstoringen) of fluctuaties in haar omgeving doorstaan of overleven en zal door natuurlijke processen en medegebruik op gebiedsniveau niet wezenlijk veranderen. Robuuste natuur en veerkrachtige natuur worden ook wel als synoniemen gebruikt. Veerkracht duidt echter op 'soepelheid, lenigheid' (www.vandale.nl) en is het gevolg van mogelijkheden voor herstel. Terwijl robuuste natuur een verstoring (zoals overstroming of zware betreding) doorstaat, zal veerkrachtige natuur mogelijk verdwijnen maar zich vervolgens herstellen, bijvoorbeeld door hervestiging vanuit andere gebieden. Als natuur onvoldoende robuust of veerkrachtig is, is deze kwetsbaar voor verstoring en voor medegebruik.

Kwetsbaar betekent 'vatbaar voor verwonding of ander onheil' of 'erg gevoelig' (www.vandale.nl). Dit begrip komt niet voor in de uitwerking van de Rijksnatuurvisie, maar is van belang bij het verkennen van kansen voor robuuste natuur en natuurlijke processen. Zowel natuurlijke processen, zoals grondwaterfluctuaties, als karakteristieke natuur, zoals bepaalde ontwikkelingsstadia van vegetaties en bepaalde soorten, kunnen kwetsbaar zijn. Veel soorten en habitats zijn door ontginning en landbouwintensivering zeldzaam geworden en daardoor kwetsbaar. Vanwege deze kwetsbaarheid zijn beperkingen opgelegd voor andere functies. Maatregelen die de veerkracht en robuustheid van de natuur bevorderen, zoals meer uitwijkmogelijkheden, zullen leiden tot minder beperkingen en minder kwetsbare natuur.

\subsection{Hoe gaan beleid en beheer met deze begrippen om?}

We hebben in de vorige paragraaf enkele temen beschreven met de omschrijving van de Van Dale als uitgangspunt. De omschrijvingen worden gebruikt om het begrip robuuste natuur te kunnen positioneren (zie par. 6.1). De termen veerkracht en (hoewel in mindere mate) robuustheid worden al veelvuldig gebruikt in de wetenschappelijke literatuur en in adviezen voor beleid en beheer (Mumby et al., 2014; Sterk, 2015; Kramer \& Geijzendorffer, 2009; Mens et al., 2012). Niet altijd worden de termen eenduidig gebruikt, maar - zoals gezegd - een te strakke definitie kan juist contraproductief werken. Uiteindelijk bepalen de criteria (zie par. 5.1) wat we onder robuuste natuur in Nederland 
kunnen verstaan. In deze paragraaf beschrijven we hoe de beleid en beheer in de praktijk momenteel met de genoemde termen (robuustheid, natuurlijkheid en grootschalige dynamische natuur) omgaan.

In het huidige beleid zijn de begrippen 'grootschalig', 'half-natuurlijk' en 'multifunctioneel' uitgewerkt in de Index Natuur en Landschap in de vorm van natuurbeheertypen, landschapsbeheertypen en agrarische beheertypen (Schipper \& Siebel, 2013). De Index NL is bedoeld voor het formuleren van de doelen van het natuurbeleid, het maken van afspraken met terreinbeheerders over de te realiseren natuurkwaliteit en het evalueren van het beleid en het beheer. De beheertypen van de Index NL worden tevens gebruikt voor subsidieverlening. De provincies zijn verantwoordelijk voor het opstellen van een jaarlijks Natuurbeheerplan met beheertypenkaart en ambitiekaart. Uit de kaarten die provincies opstellen, blijkt dat er minder grootschalige natuur op de kaart staat dan tien jaar geleden (Figuur 1.3). Waarom zijn er maar weinig gebieden als 'grootschalige dynamische natuur' op de kaart gezet?
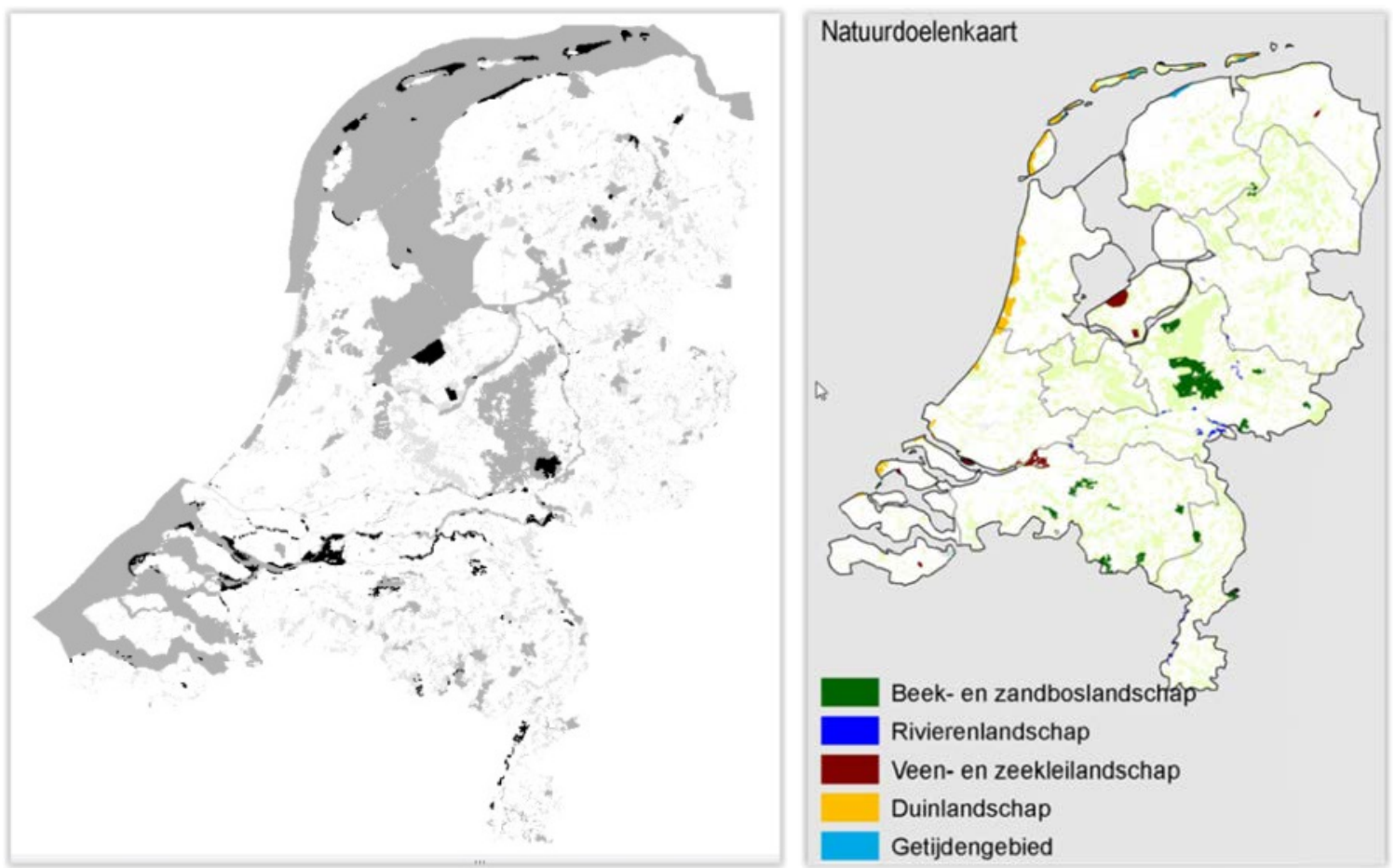

Figuur 1.3 Beheertypenkaart Index NL. Bijna alle grootschalige natuur (zwart) ligt in Natura 2000gebied (donker grijs). Links situatie 2014, rechts de natuurdoelenkaart 2005 (de natuurdoelenkaart behorende bij de Nota Ruimte; VROM, 2006).

De eisen gesteld aan 'grootschalige dynamische natuur' zijn hoog. Uit de beschrijvingen volgt namelijk dat niet alle spontane ontwikkelingen 'goed' worden bevonden. De biodiversiteit (de diversiteit aan soorten) moet namelijk wel behouden blijven. Om de biodiversiteit te behouden, zouden alle verschillende successiestadia en bijbehorende soorten (incl. toppredatoren) wel ergens in het grote gebied aanwezig moeten zijn. De levensgemeenschap moet dus ook een zekere mate van 'compleetheid' kunnen bereiken om goed te kunnen functioneren (Bal et al., 2001; Wolf, 2012). Echter als de spontane ontwikkelingen (successie) richting bos (meestal de climaxvegetatie) gaan, dan zouden de planten en dieren van open vegetaties langzaam verdwijnen en vermindert de biodiversiteit. Er moeten dus met een bepaalde frequentie spontane landschapsvormende processen optreden die het bos weer 'opruimen', zodat de hele successie weer van vooraf aan kan beginnen met pioniervegetaties. Door 'compleetheid' te waarderen, is er ook een behoefte ontstaan aan een historische of geografische referentie voor natuurlijkheid. Deze invalshoek geeft een blijvende discussie: niet alleen over de te kiezen referentie, maar vooral ook over de relevantie van de referentie voor het huidige natuurbeleid- en beheer (o.a. Klijn, 2011; Wolf, 2012). 
Een belangrijke aanname bij deze kijk op grootschalige natuur is dat ecosystemen met een hoge mate van natuurlijkheid een betere garantie bieden voor het duurzaam behoud van biodiversiteit dan ecosystemen die sterk afhankelijk zijn van het ingrijpen van de mens (Bal et al., 2001). Volgens Bal et al. (2001) wordt dit ook in het Biodiversiteitsverdrag en in de Pan-Europese Biologische en Landschaps Diversiteits Strategie benadrukt. Deze koppeling van natuurlijkheid en menselijke invloed en de bijbehorende natuurbeelden is gezien de definitie van natuur logisch, maar hebben geleid tot een polarisatie van opvattingen in het natuurbeheer waarbij 'patroonbeheer' tegenover 'procesbeheer' is komen te staan (o.a. Klijn, 2011; Wolf, 2012). Door deze hoge eisen en aanname ('compleet' en met minimale beheeringrepen) wordt grootschalige natuur in Nederland praktisch gesproken niet mogelijk geacht. Ambities voor ontwikkeling van grootschalige natuur (Figuur 1.3) zijn daarom deels teruggedraaid.

Om inzicht te krijgen hoe provincies en terreinbeheerders momenteel omgaan met grootschalige natuur, natuurlijke processen en robuuste natuur zijn interviews gehouden met een aantal ecologen van de grote terreinbeheerders en van een aantal provincies. De interviews zijn uitgewerkt in het rapport 'Kansen voor meer natuurlijkheid in Natura 2000-gebieden' (Bijlsma et al., 2016). Hier vermelden we kort de belangrijkste bevindingen uit de interviews, aangevuld met bevindingen uit documenten van deze organisaties:

- De in de jaren tachtig gemaakte koppeling van natuurlijkheid en biodiversiteit wordt nauwelijks meer gelegd. Meer natuurlijkheid wordt eerder geassocieerd met robuustheid, zelfredzaamheid en minder beheerkosten.

- De in de jaren tachtig geïntroduceerde geografische en historische referenties hebben ingeboet aan betekenis: ze verhogen de kennis van de werking van natuurlijke processen maar leveren geen na te streven doelen of beelden.

- Ambities voor ontwikkeling van grootschalig natuur zijn deels teruggedraaid. Grootschalige natuur (met minimale beheeringrepen) wordt in Nederland praktisch gesproken niet mogelijk geacht, onder andere vanwege risico's op het verdwijnen van bestaande waarden (soorten, cultuurhistorie) die zeldzaam of bedreigd zijn, successiestadia en vanwege aanzienlijke maatschappelijke en bestuurlijke knelpunten.

- Grootschalige natuur wordt alleen nog daar gepland waar processen en relaties op landschapsschaal nog actief en mogelijk zijn. Grootschalige beheertypen worden nu via beheerders ingebracht en niet door de provincie gestuurd. Het gaat hierbij bijv. om terreinen met een langjarige spontane ontwikkeling, al dan niet onder invloed van begrazing.

- Principiële discussies over patroonbeheer versus procesbeheer doen zich bij terreinbeheerders nauwelijks meer voor. Uitgangspunt is niet meer 'natuurlijkheid', maar 'natuurlijker'. Meer natuurlijkheid wordt afgewogen ten opzichte van bestaande waarden, beoogde functies en doelen en waar wenselijk bijgestuurd met beheer.

- Het streven naar meer natuurlijkheid in het beheer is niet nieuw. Aspecten van meer natuurlijkheid (natuurlijke verjonging, dood hout, successie, jaarrond begrazing, herstel van hydrologische systemen) zijn sinds de jaren tachtig integraal onderdeel van het natuurbeheer.

- De provincie Noord-Holland heeft in 2015 een verkenning uitgevoerd naar mogelijkheden voor meer natuurlijke processen in Noord-Holland op basis van een natuurdoeltypekaart uit 2002 (NH, 2015). Zij komt tot de conclusie dat in de nagenoeg natuurlijke- en begeleid natuurlijke typen als de Waddenzee, duinen en moerassen betrekkelijk weinig winst valt te behalen, omdat natuurlijke processen daar al een belangrijke rol spelen. De grootste winst valt volgens hen te behalen in de half-natuurlijke natuur (de veenweidereservaten) en bij de multifunctionele natuur (agrarisch natuurbeheer en het beheer van recreatiegebieden).

- In het natuurbeleid en bij de terreinbeheerders gaat het streven naar robuustheid nog niet direct samen met het meer sturen op natuurlijke processen, maar hangt veeleer samen met het vergroten van natuurgebieden (EL\&I, 2013; DR, 2014; SBB, 2015; NM, 2012). Door bestaande natuurgebieden te vergroten en te verbinden, ontstaat een robuust natuurnetwerk. In grote eenheden natuur is vervolgens wel meer ruimte voor natuurlijke (landschapsvormende) processen.

Hieruit blijkt dat de ideeën uit de natuurvisie nog geen gemeengoed zijn en vragen om nadere concretisering. 


\section{Project robuuste natuur: onderzoeksvragen en methode}

\subsection{Onderzoeksvragen}

Uit de Natuurvisie blijkt dat het kabinet naar een robuuste en veelzijdige natuur wil, die de invloed van de samenleving kan verdragen en daar bij kan gedijen. Deze natuur moet passen bij het veranderende klimaat, maximaal aansluiten bij natuurlijke processen, duurzaam zijn, een betaalbaar en toekomstbestendig natuurbeheer en haalbare doelen hebben. Veel geld stoppen in beheer vindt het kabinet niet duurzaam. Vrijuit geïnterpreteerd betekent dit dat robuuste natuur geen last heeft van stikstofdepositie of verdroging, een nuttige functie heeft, maatschappelijke problemen oplost, je er geld mee kan verdienen, je er lekker in kan wandelen en van genieten en het beheer bijna niets kost. Wie wil er nu geen toekomstbestendige robuuste natuur?

Maar wat verstaan we nu onder robuuste, toekomstbestendige, veelzijdige, zelfredzame, veerkrachtige natuur? Dit rapport heeft als doel om de bovenstaande ideeën uit de natuurvisie te concretiseren. Daarvoor zoeken we naar meer mogelijkheden voor combinatie van robuuste natuur met andere maatschappelijke opgaven. Zijn er in Nederland mogelijkheden voor robuuste natuur of is het idee te mooi om waar te zijn? Misschien is een stap in de richting van robuustere natuur ook al mooi. Waar liggen kansen? Wat moet daarvoor gebeuren?

De onderzoeksvragen zijn:

- Wat verstaat men onder robuuste natuur, natuurlijkheid en hoe gaat men daarmee om?

- Wat zijn criteria voor succesvolle robuuste natuur en wat zijn mogelijke consequenties?

- Wat zijn de mogelijkheden voor meer natuurlijke processen buiten de kaders van Natura 2000?

- Wat zijn mogelijke maatschappelijke opgaven en wat zijn daarbij de kansen (vrijheidsgraden) voor robuuste natuur?

- Hoe kunnen de criteria worden gewogen en kunnen daarmee kansrijke gebieden op de kaart worden onderscheiden?

De eerste onderzoeksvraag is al aan de orde gekomen in hoofdstuk 1. De aanpak van de andere vragen over de criteria en de mogelijkheden voor robuuste toekomstbestendige natuur met meer ruimte voor natuurlijke processen in combinatie met maatschappelijke opgaven en gebruiksfuncties wordt beschreven in paragraaf 2.2.

\section{$2.2 \quad$ Methode}

Deze paragraaf beschrijft de verschillende stappen om de criteria die robuuste natuur kenmerken, te duiden en de kansrijke gebieden voor ontwikkeling van robuuste natuur in kaart te brengen.

De aanpak bestaat uit de volgende stappen:

1. Aan de hand van een aantal voorbeeldgebieden (de Best Practices) worden de criteria voor Robuuste Natuur bepaald (zie paragraaf 2.2.1).

2. Aan de hand van de vraag naar ecosysteemdiensten van gesignaleerde maatschappelijke opgaven worden de criteria voor Robuuste Natuur op basis van de voorbeeldgebieden aangevuld (zie paragraaf 2.2.2).

3. Water is het leidende principe. Met andere woorden: 'het gebied' (= de eenheid van de kansenkaart) is een watersysteemeenheid (zie paragraaf 2.2.3).

4. Van criteria naar kansrijkdom. Bij deze criteria worden kaarten (GIS-bestanden) gezocht die het betreffende criterium ruimtelijk weergeven. De kaarten worden met elkaar in GIS gecombineerd en de criteria krijgen per watersysteemeenheid een waarde die je kan optellen. Hoe hoger de som van die waarden, hoe kansrijker het gebied (zie paragraaf 2.2.4). 
5. Het resultaat kan afhankelijk van het belang worden gewogen. Bijvoorbeeld door de criteria die het belang van 'meekoppelen met klimaatverandering' benadrukken een hogere waarde te geven, tellen ze zwaarder mee in de kansenkaart voor Robuuste Natuur (zie paragraaf 2.2.5).

\subsubsection{Best practices}

Met een definitie van robuustheid (uit par 1.3) weten we nog niet hoe die robuuste natuur eruitziet. Welke natuurgebieden in Nederland beschouwen we als robuust? Wat zijn dan de criteria die deze natuur robuust maken? En wat kunnen we daarvan leren? Uiteindelijk bepalen die criteria dus wat we onder robuuste natuur in Nederland verstaan. Met een beschrijving van 'best practices', goede voorbeeldgebieden proberen we deze vragen te beantwoorden. De gedachte is dat er met de juiste criteria gebaseerd op deze goede voorbeelden vervolgens elders kansrijke gebieden kunnen worden geselecteerd waardoor de ontwikkeling gepaard gaat met minder problemen, minder kosten, haalbare doelen en betere eindresultaten. Het is dus belangrijk de 'best practices' te kennen om potentiële gebieden hiermee te kunnen vergelijken. Een goed begrip van de context, de randvoorwaarden en de kritieke succesfactoren zijn daarbij essentieel.

De gebieden die wij, het onderzoeksteam, op basis van onze kennis het robuustst vonden, hebben we als best practice gekozen. In deze gebieden moet de natuur er al enige tijd min of meer zijn gang hebben kunnen gaan en moeten natuurlijke processen daarbij een belangrijke rol spelen. Omdat de selectie van best practices heel bepalend is, moeten de gekozen gebieden bovendien een zo breed mogelijk spectrum van criteria en bijzondere omstandigheden in beeld brengen. De gekozen voorbeeldgebieden zijn beschreven en in deze gebieden is gezocht naar criteria waaruit blijkt dat de natuur robuust en de ontwikkelingen succesvol zijn, bijvoorbeeld:

- Er worden spectaculaire soorten waargenomen: zeearend, witwangsterns, bevers en/of otters.

- Er is ruimte voor de natuurlijke processen (meandering, kwel, overstroming, wilde kuddes).

- De uitgangssituatie van een gebied heeft geen of weinig kwetsbare natuurwaarden en/of cultuurhistorische waarden die bij de ontwikkeling van robuuste natuur verloren kunnen gaan en die beslist behouden moeten worden.

- $\mathrm{Er}$ is een maatschappelijk draagvlak en betrokkenheid mede door meekoppelkansen zoals waterberging en veiligheid (zie ook van Hattum et al., 2014. Water en Natuur: Een mooi koppel!).

- Er is urgentie, bevlogenheid bij trekkers, bestuurlijk draagvlak, koppelbare budgetten.

Uit de best practices kunnen ook randvoorwaarden en de keerzijde van de succescriteria worden herleid, zoals

- Geen of zo min mogelijk schade aan gewassen of roerend goed.

- Geen extra risico's voor verkeersveiligheid, waterveiligheid.

De best practices en de criteria die daaruit zijn afgeleid, worden beschreven in hoofdstuk 3.

\subsubsection{Vraag naar ecosysteemdiensten}

Kansen voor ontwikkeling van robuuste natuur te midden van de samenleving nemen toe naarmate er mogelijkheden zijn om synergie met ecosysteemdiensten en met maatschappelijke opgaven te realiseren. In de zoektocht naar mogelijke locaties voor robuuste natuur is het daarom van belang om aan te sluiten bij de maatschappelijke vraag naar ecosysteemdiensten. De potentie voor ecosysteemdiensten staat sinds de Millenium Ecosystem Assesment in 2005 volop in de belangstelling, is verwerkt in de biodiversiteitsdoelstellingen en onderwerp van beleidsstudies. Zo zijn voor de Balans van de Leefomgeving vraag en aanbod van de ecosysteemdiensten beschreven en in een vervolgproject is deze vraag en aanbod in kaart gebracht (De Knegt et al., 2014; De Knegt et al., in prep.). Voor dit rapport waren niet de aanwezigheid van ecosysteemdiensten (= aanbod), maar was juist de vraag ernaar interessant. Deze in kaart gebrachte vraag is aanvullend op de criteria uit de 'best practices', omdat het merendeel van deze voorbeeldgebieden al enkele decennia geleden ontwikkeld is. De resultaten van deze studie en in hoeverre we gebruikmaken van de in kaart gebrachte vraag naar ecosysteemdiensten als criteria, worden beschreven in hoofdstuk 4 . 


\subsubsection{Water als leidend principe}

Welk ruimtelijk schaalniveau is van belang voor robuuste natuur? Kansen voor meer natuurlijke processen en natuurlijke heterogeniteit doen zich immers voor op elk schaalniveau. Echter, landschapsvormende en hydrologische processen doen zich vooral voor op regionaal niveau en hebben daarom een bepaalde ruimte nodig voor een zo optimaal mogelijk effect. Wat is deze ruimte, m.a.w. wat is een optimale gebiedseenheid voor 'landschap' en 'hydrologie'?

Het resultaat van de landschapsvormende processen uit het verleden - met andere woorden: hoe erosie en sedimentatieprocessen door ijs, zee, rivieren en wind, maar ook hoe stagnerend water het landschap in Nederland hebben gevormd en de invloed van de mens daarop - is vastgelegd op de geomorfologische kaart (vorm en ontstaanswijze) en de bodemkaart (basisindeling bodems). Een combinatie van deze kaarten is de "Landschappelijke bodemkaart" (Figuur 2.1 Van Delft et al., 2015). De Ecoregio's op deze kaart representeren de ruimtelijke variatie van de landschapsvormende processen uit het verleden, maar ook de invloed van de mens daarop.
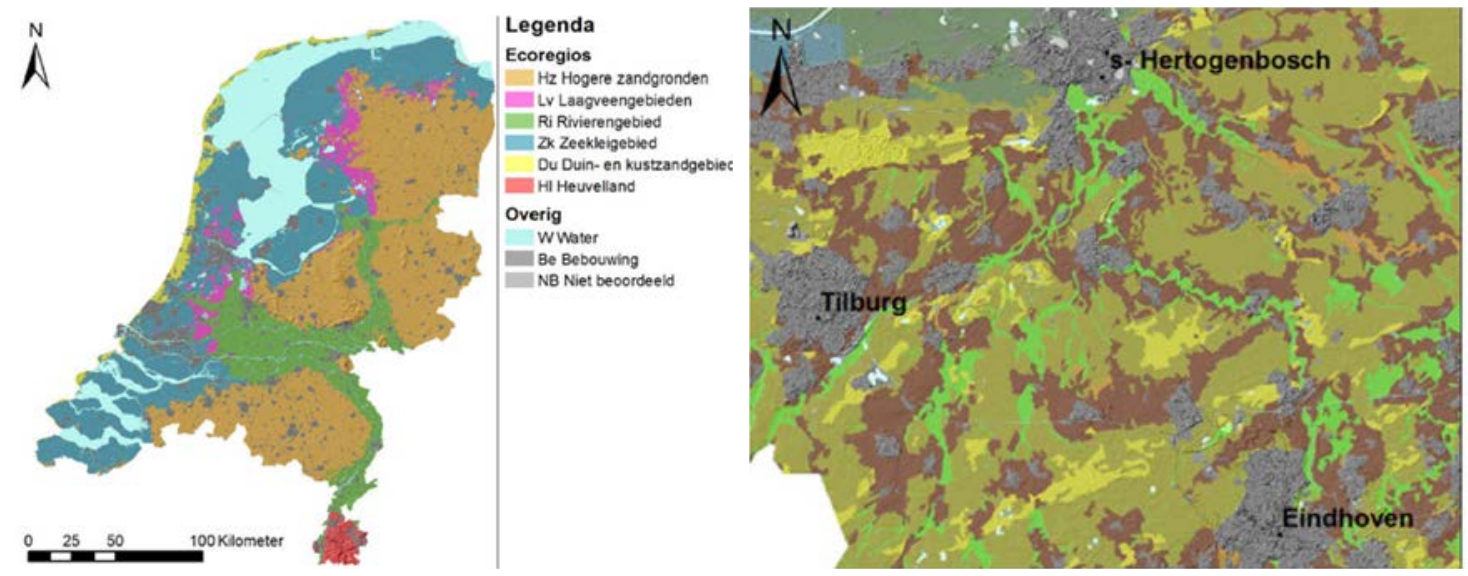

Legenda
Hz Hogere zandgronden
HzG Glaciale gebieden
HzS Stuifzandgebieden
HzD Dekzandgebieden
HzH Hoogvenen
HzB Beekdalen
HzO Oude bouwlanden
Hz Nader te bepalen
Overige ecoregios
Ri Rivierengebied
Zk Zeekleigebied
Overig
W Water
Be Bebouwing
NB Niet beoordeeld

Figuur 2.1 De ecoregio's (links) en de ecosecties (rechts) van de landschappelijke bodemkaart (Van Delft et al., 2015).

De landschappelijke bodemkaart bevat gedegen informatie over actuele en potentiële gebieden (= gebieden waar op basis van de bodeminformatie duidelijk wordt dat de processen er in het verleden actief waren) voor landschapsvormende processen, zoals stuifzandgebieden en beekdalen. De kaart gebruiken we om de potenties van een aantal van deze processen beter te lokaliseren. Echter, als gebiedsindeling voor kansrijke robuuste natuur is de kaart minder geschikt. De gebiedseenheden van deze ecoregio's, bijvoorbeeld 'Hoger zandgronden' en 'zeekleigebied', zijn namelijk te weinig specifiek en te grootschalig om als eenheid te dienen voor een kansrijkdomkaart. De gebiedsindeling moet aansluiten bij de ruimte die de processen nodig hebben om zo ongestoord mogelijk te verlopen. Zo is rivierdynamiek in het hele rivierengebied praktisch niet haalbaar. De ecosecties op de kaart, bijvoorbeeld stuifzandgebieden en beekdalen, zijn veelal te gedetailleerd begrensd om als gebiedsindeling te dienen.

Naast de landschapsvormende processen zijn het de hydrologische processen die om een landschappelijke gebiedsindeling vragen, maar nu gebaseerd op bovengrondse en ondergrondse waterstromen. Maatregelen voor herstel van de hydrologie hebben vaak invloed op de hele watersysteemeenheid. Begrenzing van hydrologische eenheden is daarom ook van belang bij afwentelingen tussen landbouw en natuur. Een door hydrologie begrensde eenheid voorkomt dat natuurlijke hydrologische processen onvoldoende de ruimte krijgen of dat er natschade voor de landbouw ontstaat en er compenserende maatregelen moeten worden genomen.

Er zijn watersysteemeenheden-kaarten beschikbaar op verschillende schaalniveaus. De hydrologische gebiedsindeling die we hebben gebruikt, is gebaseerd op 123 waterhuishoudkundige deelstroomgebieden op basis van hydrologische grenzen (Van Boekel et al., 2013). Deze 


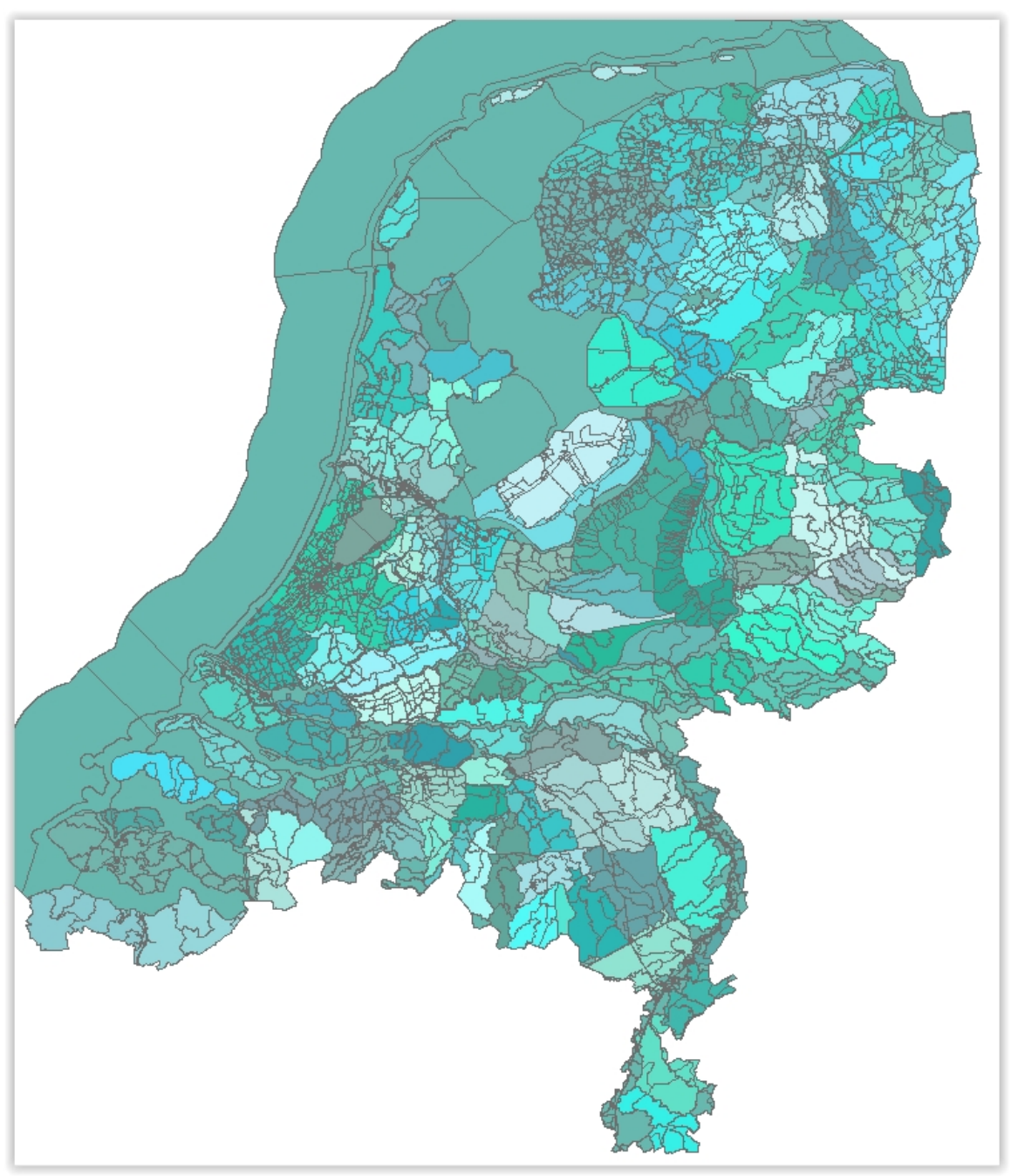

Figuur 2.2 Deelstroomgebieden (kleur) en watersysteemeenheden (vlakjes) van Aquarein20090723.

\subsubsection{Van criteria naar kansrijkdom voor robuuste natuur}

De criteria verkregen uit de best practices $(\mathrm{H} 3)$ en de maatschappelijke opgaven (H4) zijn samengevoegd in een Tabel waarna vervolgens zo veel mogelijk landelijke kaarten zijn gezocht die het betreffende criterium ruimtelijk weergeven of een benadering van het criterium ruimtelijk weergeven (Tabel $5.1 \mathrm{H} 5$ ). De beschikbare kaarten zijn omgezet in gridbestanden van $25 * 25 \mathrm{~m}^{2}$. De legenda's van de kaarten zijn versimpeld door alleen die legenda-eenheden te selecteren die nodig zijn voor de criteria; de overige legenda eenheden zijn op 0 gezet. De criteria en de bijbehorende landelijke kaarten staan vermeld in paragraaf 5.1 .

Een legenda-eenheid die van belang is voor robuuste natuur krijgt de waarde 1 mits hij op een minimumoppervlak voorkomt. Een legenda-eenheid die negatief kan uitpakken voor de kansen voor ontwikkeling van robuuste natuur krijgt de waarde -1 . Het minimum-oppervlakteaandeel waarmee een legenda-eenheid moet voorkomen binnen de basiseenheid is een aanvullend criterium voor de kansrijkdom. Het meenemen van een minimumoppervlak voorkomt dat de onnauwkeurigheden (bijvoorbeeld zeer kleine vlakjes door onnauwkeurigheden in de begrenzing) in GIS gaan meetellen in de kansrijkdom. Bovendien is een bepaald oppervlakteaandeel nodig om ook voldoende effect te kunnen bereiken. Wat het optimale oppervlakte aandeel is, is afhankelijk van het criterium en meestal 
is het vaststellen van een exact aandeel enigszins willekeurig. De waarden die we gekozen hebben, zijn daardoor een expertoordeel, maar kunnen bij andere inzichten worden aangepast. Nadat alle criteria een waarde 1, 0 of -1 hebben gekregen, kunnen de waarden per gebied (de

watersysteemeenheid) worden opgeteld. Hoe hoger de som van die waarden, hoe kansrijker het gebied. De waardenberekening op basis van het oppervlakteaandeel wordt beschreven in paragraaf 5.2 .

\subsubsection{Weging van belangen}

Standaard hebben alle criteria dus een waarde 1, 0 of -1 gekregen als het oppervlak groter is dan het minimale oppervlakte-aandeel. Soms zijn maatschappelijke opgaven zo urgent dat ze een hogere prioriteit zouden moeten krijgen. Dat kan door de waarde van een specifiek criterium te verdubbelen of zelfs te vertienvoudigen. Beleidsmakers kunnen bijvoorbeeld de effecten van klimaatverandering urgent vinden. Door de gebieden met klimaatcorridors, waterberging e.d. hogere waarden te geven, tellen ze zwaarder mee in de kansrijkdomkaarten. Door de weegfactoren te variëren, ontstaan verschillende kansrijkdomkaarten. 


\section{Beschrijving en analyses van "best practices"}

Welke gebieden in Nederland beschouwen we als robuuste natuur? Waarom vinden we die natuur robuust en wat maakt deze gebieden een succesverhaal? Wat kunnen we daarvan leren? Om hierin enig inzicht te krijgen, hebben we zes gebieden gekozen die we op basis van onze kennis robuust vinden: 1. de Veluwezoom, 2. het Hunzedal, 3. de Oostvaardersplassen, 4. de Gelderse poort, 5. de Noord-Hollandse duinen en 6 . het Geuldal. Bij deze keuze lieten we ons sturen door de veronderstelling dat de natuur er al enige tijd min of meer zijn gang heeft kunnen gaan en dat natuurlijke processen daarbij een belangrijke rol spelen. Omdat de selectie van best practices heel bepalend is, zijn de gebieden zo gekozen dat zij een zo breed mogelijk spectrum van criteria en bijzondere omstandigheden in beeld brengen. Ze liggen daartoe verspreid over de verschillende ecoregio's (zie paragraaf 2.2.3) van ons land (Figuur 3.1). Hieronder worden de gebieden kort beschreven en de belangrijkste criteria voor succes, voorwaarden en keerzijden genoemd (zie paragraaf 2.2.1). In Bijlage 1 staat meer informatie over deze gebieden.

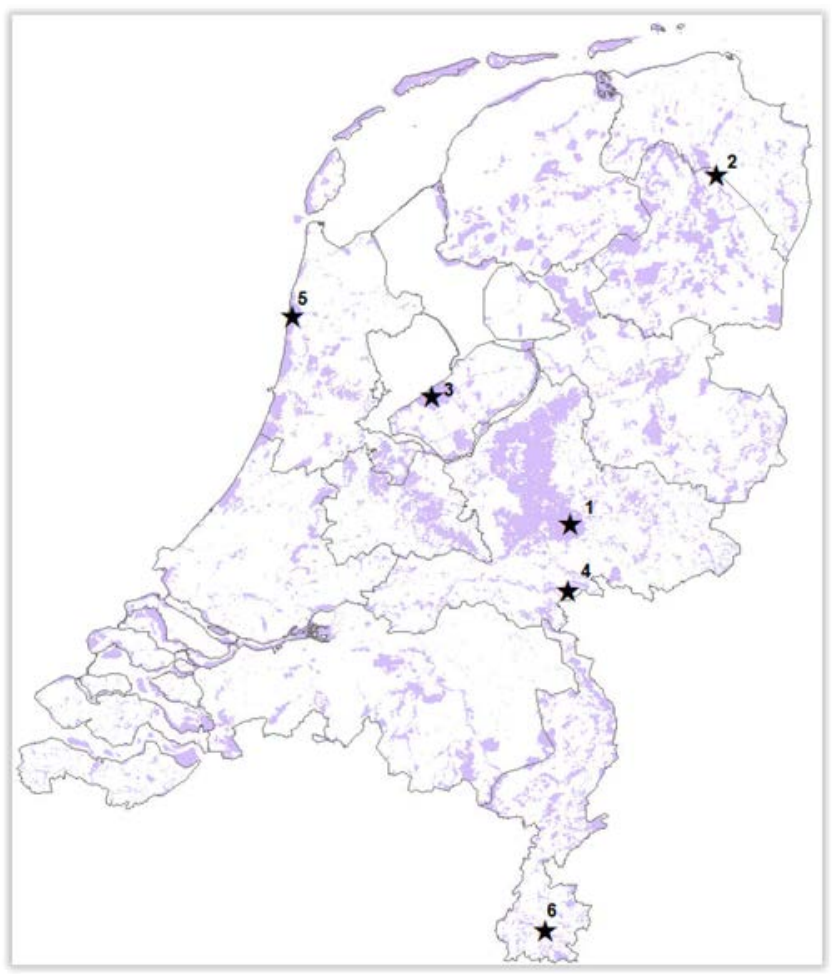

Figuur 3.1 Locatie best practices

\subsection{Criteria op basis van de gekozen gebieden}

\section{Veluwezoom}

Nationaal park De Veluwezoom is een ruim 5000 ha groot bos- en heidegebied en onderdeel van het Natura 2000-gebied 'Veluwe'. Dit stuwwallenlandschap is verbonden met het rivierenlandschap via 'ecologische poorten' als Soerense Poort en Havikerpoort. Het gebied bestaat uit vele gradiëntrijke overgangen van hoog naar laag (reliëf), van arm naar rijk (bodem) en van droog naar nat (vochthuishouding). Grote delen van het gebied zijn nooit ontgonnen geweest. Al dertig jaar vindt op ca. 2/3 van het gebied een terughoudende vorm van beheer plaats, waarbij de natuur mag bepalen wat de richting is waarin het landschap zicht ontwikkelt. De nadruk ligt daarbij op soorten die het uiterlijk van het landschap mede bepalen, bijvoorbeeld de diverse dominante boomsoorten en grotere 
zoogdiersoorten. Deze mogen zich zo veel mogelijk op eigen kracht vestigen, verspreiden, sterven door ouderdom, ziekte, predatie e.d. en niet door oogst. Kadavers en dood hout blijven als biomassa liggen.

Waarom is het een succes (zie paragraaf 2.2.1)?

- Bossen en heiden zijn gevarieerder geworden in samenstelling en structuur.

- Langjarige continuïteit in beheerstrategie zorgt voor onverwachte ontwikkelingen in de heide die van wetenschappelijk belang zijn.

- Groot gebied waardoor er kuddes grote zoogdieren kunnen voorkomen die zorgen voor variatie in vegetatiestructuur.

- Variatie en het zien van wild wordt gewaardeerd door recreanten. Zichtbaarheid wild is een aandachtspunt (schuw door afschot).

- Het reliëf zorgt voor een rijke variatie in abiotische gradiëntsituaties die ecologisch gezien zeer waardevol zijn.

- De Veluwse poorten open (vrij van bebouwing) houden en herstel overgangen van het stuwwallenlandschap naar het rivierenlandschap (rondtrekkende dieren, kwel).

Voorwaarden, beperkingen en keerzijde

- Zonering in beheerstrategieën: in sommige deelgebieden wordt ingegrepen volgens de halfnatuurlijk beheerstrategie om bepaalde cultuurhistorische waarden te behouden, terwijl in andere deelgebieden de natuurlijke processen meer hun gang kunnen gaan.

- Selectief ingrijpen nodig om de heide open te houden.

- Door allerlei wettelijke, maatschappelijke en praktische redenen kunnen opbouw en populatieomvang van edelherten, damherten en wilde zwijnen niet door natuurlijke selectiemechanismen worden gereguleerd.

\section{Hunzedal / Zuidlaardermeerpolders}

Het Hunzedal / de Zuidlaardermeerpolders is een ruim 3000 ha groot beekdal. De Hunze ontspringt op het Drents plateau en stroomt onderlangs de Hondsrug naar de stad Groningen, om uiteindelijk uit te monden in de Waddenzee. Met de intensivering van de landbouw halverwege de vorige eeuw werd de Hunze gekanaliseerd en werden sloten aangelegd om het kwelwater onder aan de Hondsrug af te voeren. Ook werden verspreid over het Hunzedal grondwaterwinningen ingericht. Sinds de publicatie van de Hunze-visie in 1995 is ruim 3000 ha nieuwe natte natuur ontwikkeld. Bij de ontwikkeling is gezocht naar functiecombinaties, zoals de meekoppeling met waterberging, waterzuivering en waterwinning. De waterbergende functie van de Zuidlaardermeerpolders bleek bijvoorbeeld van doorslaggevend belang om de stad Groningen droog te houden. De kansen voor natte en procesgerichte natuurontwikkeling in het Hunzedal zijn buitengewoon groot door het optreden van kwel vanuit de Hondsrug.

Waarom is het een succes?

- Spectaculaire natuurontwikkeling met voor Nederland unieke broedkolonies van witwangsterns, witvleugelsterns. Daarnaast ook bezoek en vestiging van iconische soorten als bever, otter en zeearend.

- Groot, vrijwel aaneengesloten gebied waardoor het waterbeheer in potentie optimaal kan worden afgestemd op de natuur.

- Herstel van kwelnatuur was nog steeds mogelijk.

- Verankering binnen het provinciaal, nationaal en Europees beleid.

- Grondverwerving relatief eenvoudig omdat boeren natte lage gronden konden ruilen voor beter bewerkbare, hoger gelegen gronden.

- Door natuurontwikkeling verbeterde natuurlijke zuivering van drinkwater, waterbergingsgebied en een aantrekkelijkere omgeving om te wonen, werken en recreëren waarvan lokale ondernemers profiteren.

- Hunzevisie als krachtig communicatie-instrument voor het enthousiasmeren van de verschillende belanghebbenden.

- Samenwerking tussen alle belanghebbenden, zoals overheden, waterschappen, natuurbeschermingsorganisaties, ondernemers, bewoners en vrijwilligers. 
Voorwaarden, beperkingen en keerzijde:

- Vooralsnog te weinig aaneengesloten areaal voor kenmerkende natuurlijke processen als sedimentatie en erosie, stroming en periodieke overstroming en opvangen van toekomstige piekbelastingen.

- Waterkwaliteit (gehalten aan meststoffen, bestrijdingsmiddelen en medicijnresten) is nog niet op orde.

- De waarde van het beekdalsysteem in de klimaatproblematiek $\left(\mathrm{CO}_{2}\right.$-vastlegging en duurzame energie) wordt nog onvoldoende benut.

\section{Oostvaardersplassen}

De Oostvaardersplassen is een 3600 ha groot moerasgebied. Na het droogvallen van Flevoland in 1968 werd er riet uitgezaaid als eerste stap in de ontginning. In het laagste en natste deel ontstond, door duizenden ruiende grauwe ganzen, een mozaïek van meertjes en rietbegroeiing. Hier kwamen talrijke andere soorten (broed)vogels in groten getale op af. De spontane en spectaculaire natuurontwikkeling was een stimulans om het gebied te beschermen i.p.v. te ontwikkelen. Om het rietmoeras te kunnen ontlasten van de intensieve begrazing van toenemende aantallen ganzen, was er behoefte aan graasgronden in het omliggende droge gebied. Heckrunderen, konikpaarden en edelherten werden geïntroduceerd om deze droge zone te ontwikkelen tot de gewenste grazige vegetatie en om de struwelen te beteugelen. Natuurlijke processen krijgen de ruimte; het waterpeil kan variëren onder invloed van neerslag en verdamping en de populaties grote grazers kunnen zich ontwikkelen zonder actief beheer, zoals afschot of bijvoederen. Deze processen leiden in de praktijk niet altijd tot het gewenste behoud van beschermde soorten, waardoor er nu toch weer plannen zijn om in te grijpen.

Waarom is het een succes?

- Internationaal kerngebied voor moerasvogels: zeer hoge aantallen broedparen van zeldzame moerasvogels zoals baardmannetjes.

- Spontane vestiging van broedende zeearenden na eeuwen van afwezigheid.

- Bron van inspiratie wat de denkbeelden over natuur en natuurbeheer in Nederland sterk heeft beïnvloed.

- Onderscheiding met het Europees diploma voor bijzondere natuur en excellent beheer door de Raad van Europa.

- Groot gebied met populatiedynamiek van grote grazers.

- Wetenschappelijke experiment; natuurontwikkeling o.i.v. begrazing.

Voorwaarden, beperkingen en keerzijde:

- Geïsoleerd gelegen gebied, weinig verbinding met andere (natuur)gebieden, vismigratie niet mogelijk.

- Recreatieve mogelijkheden zijn beperkt.

- Maatschappelijk weerstand met betrekking tot het gevoerde beheer i.v.m. dierenwelzijn.

- Door toenemende aantallen grote grazers verdwijnen veel broedvogels en neemt de variatie in vegetatiestructuur af.

- Grote carnivoren met invloed op populatiedynamiek grote grazers ontbreken.

\section{Gelderse Poort}

De Gelderse Poort is een ruim 6000 ha groot gebied bestaande uit de rivieren Waal, Rijn en IJssel, en aanliggende uiterwaarden, ingeklemd tussen de stuwwallen van Nijmegen en het Montferland. De invloed van de rivierdynamiek wordt beperkt door dijken, kribben en stuwen (in de Rijn). In 1986 werd Plan Ooievaar gepubliceerd waarbij natuurherstel was gekoppeld aan economische voordelen, zoals kleiwinning. In de uiterwaarden zijn nevengeulen aangelegd, zomerdijken zijn doorgestoken. Overal ontstonden plassen, moerassen en ruige ooibossen. Jaarlijks overwinteren duizenden ganzen in de Gelderse Poort. In 1995 blijkt dat rivierdynamiek tijdens piekafvoeren weer in staat is tot oevererosie en rivierduinvorming. Het gebied is door de rivierdynamiek en begrazing door paarden en runderen rijk aan gradiënten in reliëf, bodem, vocht, voedselrijkdom en vegetatiestructuur.

Waarom is het een succes? 
- Rivierdynamiek kan de ruimte krijgen en veroorzaakt overstromingen en zandverplaatsingen (erosie en sedimentatie) waardoor reliëf verandert en er weer pionierssituaties ontstaan.

- Weinig natuurwaarden aanwezig vóór ontwikkeling; omvorming landbouw in natuur.

- Rivierwater is drager van zaden over grote afstanden.

- Voorkomen van bevers, dassen, zwarte sterns, pionierplanten als riempjes en polei.

- Groot gebied waardoor kuddes grote grazers mogelijk zijn die zorgen voor variatie in vegetatiestructuur.

- Voldaan aan een behoefte aan een integrale oplossing voor meerdere problemen, waaronder landbouw, scheepvaart, grondstofwinning en natuur.

- Economische mogelijkheden die financiële drager konden zijn: zand-, klei- en grindwinning.

- Samenwerking van meerdere actoren: RWS, ARK, WNF, SBB.

Voorwaarden, beperkingen en keerzijde

- Teruggekeerde dynamiek blijft relatief beperkt: ijsgang treedt niet meer op en slibafzettingen in de uiterwaarden worden niet vaak meer geërodeerd. Waar dit ongewenste situaties oplevert, wordt beheer ingezet. Voor hoogwaterveiligheid bijvoorbeeld moeten doorstroomprofielen ruim genoeg blijven:

- Te hoge of te dichte opstanden worden soms gekapt. Hierdoor ontstaan ook weer kansen voor natuurontwikkeling.

- Opgeslibte uiterwaarden worden weer vergraven, ook dit levert weer nieuwe pionierssituaties.

- Verschil in toegankelijkheid voor bezoekers: Millingerwaard open, ook buiten de paden; Rijnstrangen niet toegankelijk.

\section{De kust van Noord-Holland}

Het duingebied en strand bij Noord-Holland is ca 20.000 ha groot en zeer variabel in breedte. In de $19^{e}$ eeuw is men begonnen met drinkwaterwinning waardoor de duinvalleien verdroogden. Daarnaast heeft men vanwege de waterkerende functie de stuivende duinen vastgelegd door ze met helm te beplanten. Vanaf 1990 worden door Rijkswaterstaat vooroeversuppleties uitgevoerd om de huidige kustlijn te handhaven. Al eerder was men begonnen met strandsuppleties (jaren zeventig). De laatste decennia is er aandacht voor dynamisch kustbeheer waarbij zee en wind de ruimte hebben om zand en sediment te verplaatsen. Verschillende projecten zijn daartoe uitgevoerd. Voordeel is dat er niet hoeft te worden ingegrepen na elke storm en de dynamiekafhankelijke natuurwaarden worden hersteld. Om de dynamiek van verstuiving en de invloed van de zee te bevorderen, zijn er op verschillende plekken in de brede duingebieden grote sleuven in de zeereep gegraven waarbij de veiligheid van het achterland gewaarborgd bleef. Bij 'de Kerf', nabij Schoorl, heeft dat mooie resultaten opgeleverd, ondanks dat de opening na een aantal jaren volstoof met zand.

Waarom is het een succes?

- Na de inrichting ontstonden zoet-brakovergangen met bijzondere soorten, zoals parnassia en moeraswespenorchis.

- Risicopercepties ten aanzien van waterveiligheid (je maakt toch een gat in de zeereep) zijn, mede dankzij deze pilotprojecten, bij de waterbeheerder en bij de lokale bevolking weggenomen.

- Mensen vonden elkaar en gingen ervoor; er was chemie.

- Het herstel van natuurlijke dynamiek in de duinen is ook van belang voor de waterkwaliteit van drinkwater.

- Maatregelen van het natuurbeheer kunnen worden verdisconteerd in de prijs van het drinkwater.

Voorwaarden, beperkingen en keerzijde:

- Kerven stuiven na verloop van tijd weer vol en de dynamiek neemt weer af.

- Met het verwijderen van zand, verwijder je ook mogelijk een deel van de zaadbank.

- Voor herstel van zeldzame soorten en habitats zijn veel meer verstuivingsmaatregelen in het duin nodig.

- Het duinbeheer mag niet ten koste gaan van de waterveiligheid en is alleen toepasbaar in voldoende grote gebieden.

- Het herstel van de grondwaterstanden leidde echter ook tot natschade/wateroverlast in aanliggende woonwijken en landbouwgebied (bloembollen). 


\section{Het Geuldal}

De Geul vormt van nature de verbinding tussen de Duitse Eifel en de Belgische Ardennen enerzijds en de Nederlands-Belgische Grensmaas anderzijds. Het Geuldal is relatief onontgonnen en gradiëntrijk door grote hoogteverschillen; de beek heeft voor Nederlandse begrippen hoge stroomsnelheden. Waar zij de ruimte krijgt, ontstaan hoge steilranden en een grote dynamiek. Omvallende bomen, hellingprocessen en de bouw van beverdammen zorgen voor de vorming van grindeilandjes, nieuwe nevengeulen en hoogwaterkolken. De beek krijgt een gevarieerd en breed stroombed, met verschillende stroomsnelheden. Moesdistel en kleine kaardenbol vestigen zich op grindbanken en zandafzettingen. In nieuw ontstane erosiekolken keren libellen en amfibieën terug. IJsvogels gaan broeden in de steilranden.

Waarom is het een succes?

- Stromend water, het meanderend karakter van de Geul, en de ruimte om vrij te meanderen.

- Zeer gradiëntrijk gebied. Hoogte, kalkgehalte, nutriëntenrijkdom en droog/nat. Optreden kwel.

- Aanwezigheid van slecht doorlatende lagen op hellingen waardoor bronnen ontstaan.

- Verbetering waterkwaliteit, ook belangrijk voor drinkwaterwinning.

- Compleet beekdalsysteem met bronnen, beken, rivier, plateaus, hellingen en dalen.

- Groot gebied. Lengte Geul is $50 \mathrm{~km}$.

- Soorten die hebben geprofiteerd of zouden kunnen profiteren: Spaanse vlag, vliegend hert, hazelmuis, wilde kat, bever, otter, stroomminnende vissoorten (elrits, barbeel, kopvoorn, beekdonderpad, beekprik).

- Meekoppeling met natuurlijke waterberging.

- Goede afstemming beheer en beleid. Provincie heeft beherende partijen vrijgelaten, gebaseerd op vertrouwen en resultaten.

- Gelden beschikbaar vanuit beleid voor aankoop gronden, Postcode Loterij.

- Veel aandacht voor communicatie naar grotere publiek. Voorlichting, excursies, films, etc.

Voorwaarden, beperkingen en keerzijde:

- Doorsnijding met wegen: het verkeer vormt een van de belangrijkste onnatuurlijke doodsoorzaken van bevers.

- Opheffen knelpunten vismigratie is een bedreiging voor de beekdonderpad.

- Voortgang project is afhankelijk van voortgang aankoop van gronden.

- Waterkwaliteit moet verder verbeterd worden, nog te voedselrijk en te veel bestrijdingsmiddelen vanuit de landbouw.

- Vele verschillende eigenaren, inclusief groot bovenstroomgebied in België.

- Waterwinning beperkt mogelijkheden beheermaatregelen.

De bovenstaande criteria waarom deze gebieden een succes zijn wat betreft robuuste natuur, natuurlijke processen, maar ook de randvoorwaarden en de keerzijden van deze natuur, zijn voor analyse samengevat in Tabel 5.1 .

\subsection{Keerzijde van robuuste natuur}

Samenvattend zien we dat we bij robuuste natuur in de best practices allerlei de mogelijkheden voor natuurlijke processen (hydrologie en populatiedynamiek grote grazers), ontwikkeling van bijzondere biodiversiteit en kansen voor het realiseren van maatschappelijke opgaven (meekoppelkansen) tegenkomen. Ontwikkeling van robuuste natuur zal in theorie daarom vaak leiden tot een breed scala aan positieve ontwikkelingen voor zowel natuur als mens. De positieve ontwikkelen hebben echter ook een keerzijde: wat vanuit het ene oogpunt geweldig is, is vanuit het andere een last. Het is daarom van belang om de keerzijde zo vroeg mogelijk in beeld te brengen, zodat ze met het treffen van maatregelen wellicht afdoende kunnen worden beheerst, gemitigeerd of gecompenseerd. Mits aangelegd op de juiste locatie en met de juiste maatregelen, denken we dat deze positieve ontwikkelingen veelal opwegen tegen de negatieve. Hieronder worden enkele negatieve ontwikkelingen/keerzijden - gerelateerd aan de ontwikkelingen in de best practices - nader beschreven en worden mogelijke mitigerende maatregelen genoemd: 
- Derving van landbouwinkomsten: Nieuwe (robuuste) natuur zal veelal worden aangelegd op landbouwgronden. Dit leidt tot derving van inkomsten uit de landbouw, wat duidelijk maakt dat de locatiekeuze belangrijk is om de verliezen en kosten te beperken. Verlies van landbouwgrond kan tot weerstand leiden; zie bijvoorbeeld de discussie rond de ontpoldering van de Hedwige-polder in Zeeland. Marginale, relatief goedkope landbouwgronden zijn daarom het aantrekkelijkst voor de aanleg van robuuste natuur. In deze gebieden kunnen goede ruilmogelijkheden met elders aangekochte landbouwgronden bestaan die tot geen of weinig weerstand leiden.

- Verlies van bestaande waarden: Naast derving van landbouwinkomsten kunnen ook bestaande natuur- en cultuurhistorische waarden onder druk komen te staan of verdwijnen. Kwetsbare soorten zoals Rode Lijstsoorten kunnen verdwijnen wanneer bestaand habitat transformeert in een andere habitat. Ook cultuurhistorische waarden kunnen verloren gaan. Binnen robuuste natuur zullen cultuurhistorische objecten en kwetsbare soorten om aandacht en beheer vragen als de beheerder ervoor kiest deze waarden te behouden.

- Wateroverlast en veiligheid: In veel gevallen zal het gaan om de aanleg van waterrijke robuuste natuur. Dit kan op verschillende wijzen tot ongewenste ontwikkelingen leiden:

- Landschapsvormende bevers: Waterrijke gebieden trekken bevers aan en de soort is in Nederland met een sterke opmars bezig (zie fig. 3.2). Zijn landschapsvormende kwaliteiten hebben een keerzijde. Waterschappen zien een reëel risico voor het ontstaan van schade aan waterkeringen en ongewenste waterpeilstijgingen door aanwezigheid van holen, burchten en dammen. De openbare veiligheid kan hierdoor in het geding raken. In Brabant hebben de Waterschappen Aa en Maas, Brabantse Delta en Dommel inmiddels een Beverprotocol opgesteld om de negatieve effecten te verminderen (Cox et al., 2014).

- Stuwing van rivierwater: De natuurlijke ontwikkeling van rivierbossen kan in perioden met neerslagpieken leiden tot teveel stuwing van rivierwater en daarmee tot wateroverlast stroomopwaarts. Wordt echter tegelijkertijd op de andere oever een nevengeul gegraven, cyclisch beheer toegepast of een deel van de uiterwaard ontkleid, dan kan dat de afvoercapaciteit vergroten. Tegelijkertijd is ook daar weer sprake van natuurontwikkeling richting rivierbos en kansen voor robuuste natuur.

- Wateroverlast door verhoogde grondwaterstand: Een verhoogde grondwaterstand kan leiden tot wateroverlast in landbouwgebieden en urbane gebieden. Zo is het grondwaterpeil in de regio ZuidKennemerland gestegen nadat drinkwatermaatschappij PWN overstapte op diepte-infiltratie. Incidenteel treedt wateroverlast op, omdat het grondwaterpeil na perioden met hevige neerslag tijdelijk te hoog is (Kuiper \& Krajenbrink, 2013). Dit maakt duidelijk dat het meenemen van hele watersysteemeenheden een belangrijke voorwaarde kan zijn.

- Grote grazers: De landschapsvormende kwaliteiten van grote grazers vormen (vooral bij de afwezigheid van hydrologische dynamiek) een belangrijke factor bij de ontwikkeling van robuuste natuur. Dit kan op verschillende wijzen tot ongewenste ontwikkelingen leiden:

- Verkeersveiligheid: Natuurlijke predatie van grote grazers komt in Nederland nauwelijks voor. Zonder aantalsregulatie kan dat ten koste gaan van de verkeersveiligheid. Het aantal aanrijdingen blijkt positief gecorreleerd met de dichtheid van hoefdieren, hun seizoen- en dagritmen en de daarmee samenhangende trekbewegingen (Groot-Bruinderink et al., 2009). Het gaat hierbij niet alleen om de Veluwe. De toegenomen populaties damherten en reeën in Zeeland leiden bijvoorbeeld tot een toenemend aantal aanrijdingen (persbericht Koninklijke Nederlandse Jagersvereniging, 1 december 2015). Onder het motto 'beter door het geweer dan door het verkeer' pleit de KNJV voor een pro-actiever beheer van de populaties grote grazers. Zowel vanuit oogpunt van verkeersveiligheid als dierenwelzijn, omdat veel aangereden dieren een langzame en pijnlijke dood sterven. Er zijn echter ook andere maatregelen, zoals snelheidsbeperkingen, die de negatieve effecten van grote aantallen grote grazers op de verkeersveiligheid kunnen verminderen.

- Dierenwelzijn: Het thema dierwelzijn en grote grazers speelt een grote rol in de maatschappelijke discussie tijdens strenge winters. Met name in de Oostvaardersplassen waar de grote grazers officieel als 'wild' worden gehouden, waardoor de zorgplicht als 'landbouwhuisdier' niet geldt. Na aanhoudende discussie is men hier echter overgegaan tot het zogenaamde 'vroeg-reactief beheer'. Dit betekent dat dieren die met een slechte conditie de winter ingaan worden gedood, voordat ze werkelijk lijden.

- Watervervuiling, feces rondom drinkwaterputten.

- Schade aan landbouwgewassen, kwetsbare natuur en landschapselementen. 
Bij een aantal van de best practices treden deze negatieve ontwikkelingen op en worden mitigerende maatregelen genomen, zoals:

- Herinrichten en uitrasteren.

- Bosvrij houden uiterwaarden en heide.

- Populatiebeheer grote zoogdieren.

- Aanvullend maaibeheer.

De keerzijde van het nemen van deze maatregelen is dat ze extra onkosten met zich meebrengen en dus de gewenste kostenbesparing deels weer tenietdoen.

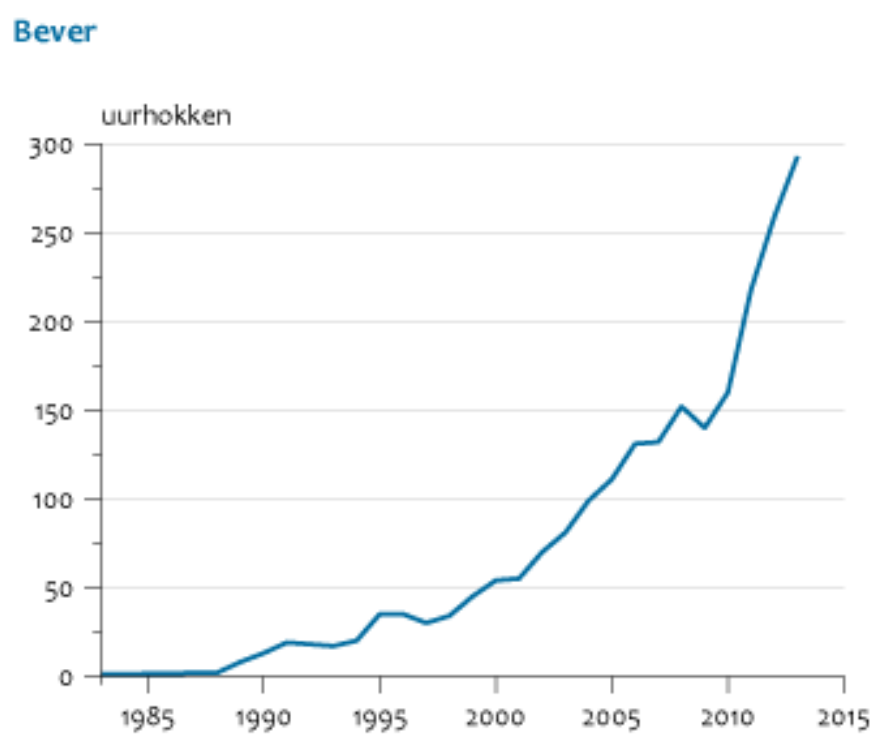

Bron: Zoogdiervereniging.

Figuur 3.2 Ontwikkeling van het aantal uurhokken met bevers in Nederland (CBS et al., 2015).

Deze keerzijden verminderen de kansrijkdom voor robuuste natuur en staan daarom als aparte categorie in Tabel 1.

Naast de keerzijde zijn er ook nog enkele andere beperkingen die maken dat de robuuste natuur zich (nog) niet ten volle kan ontwikkelen. De belangrijkste genoemde beperkingen zijn:

- Waterkwaliteit nog niet op orde.

- Ruimtelijke condities nog niet op orde; gebied onvoldoende aaneengesloten. 


\section{$4 \quad$ Veelzijdige natuur midden in de samenleving}

Sinds de Millenium ecosysteem assessment (MEA, 2005) in 2005 is er veel aandacht voor het onderwerp ecosysteemdiensten. De inzichten over het nut en het belang van biodiversiteit voor geleverde ecosysteemdiensten, worden gebruikt om de investeringen in natuur en biodiversiteit te stimuleren. Met deze aandacht voor ecosysteemdiensten kan de waarde van de biodiversiteit voor mens en maatschappij expliciet worden gemaakt. Een dienst als schone lucht of schoon water lijkt 'gratis', maar heeft een economische waarde. Door deze waarde zichtbaar te maken, worden de diensten ook economisch interessant. Kansen voor ontwikkeling van robuuste natuur te midden van de samenleving nemen dus toe naarmate er mogelijkheden zijn om synergie met ecosysteemdiensten en met maatschappelijke opgaven te realiseren. In de zoektocht naar mogelijke locaties voor robuuste natuur is het daarom van belang om aan te sluiten bij de maatschappelijke vraag naar ecosysteemdiensten.

\subsection{Levering van diensten door ecosystemen}

Het rijk heeft als doel gesteld dat in 2020 het natuurlijk kapitaal is behouden en duurzaam wordt gebruikt. Met 'natuurlijk kapitaal' wordt het vermogen van de natuur bedoeld om goederen en diensten te kunnen leveren, ook wel ecosysteemdiensten genoemd. Daarbij gaat het om:

1. Productiediensten; het vermogen van ecosystemen om te voorzien in goederen, zoals hout en vis.

2. Regulerende diensten; het vermogen van ecosystemen om processen te reguleren, zoals het zuiveren van water of bescherming van de kust.

3. Culturele diensten; het vermogen van ecosystemen om immateriële voordelen te bieden bij een verblijf in ecosystemen, zoals ruimte voor recreatie. Deze categorie bundelt vooral de materiële en immateriële waarden die mensen aan natuur hechten vanuit recreatieve, spirituele en emotionele aspecten.

De Nederlandse samenleving maakt veelal ongemerkt gebruik van deze ecosysteemdiensten. Doorgaans valt pas op dat ze niet (meer) worden geleverd wanneer problemen ontstaan. Bijvoorbeeld bij een overstroming door beken na een hevige neerslagperiode of omdat alternatieve kostbare technische maatregelen genomen dienen te worden. Ecosysteemdiensten worden niet alleen geleverd door natuurgebieden, maar ook door agrarische gebieden en zelfs in urbane gebieden. Van de meeste ecosysteemdiensten wordt het grootste deel echter geleverd door natuurgebieden (Figuur 4.1). Dit terwijl de oppervlakte natuur vele malen kleiner is dan de oppervlakte agrarisch gebied. Doordat het huidige agrarische gebied vooral bestaat uit monofunctionele, intensieve landbouw, kunnen slechts enkele ecosysteemdiensten in beperkte mate worden geleverd. Bij een duurzamere landbouw zouden dat er meer kunnen zijn. De bijdrage van het urbane gebied aan het totale aanbod aan ecosysteemdiensten in Nederland is vooralsnog eveneens beperkt, maar kan desalniettemin toenemen met een duurzamere groene inrichting van het stedelijk gebied. 


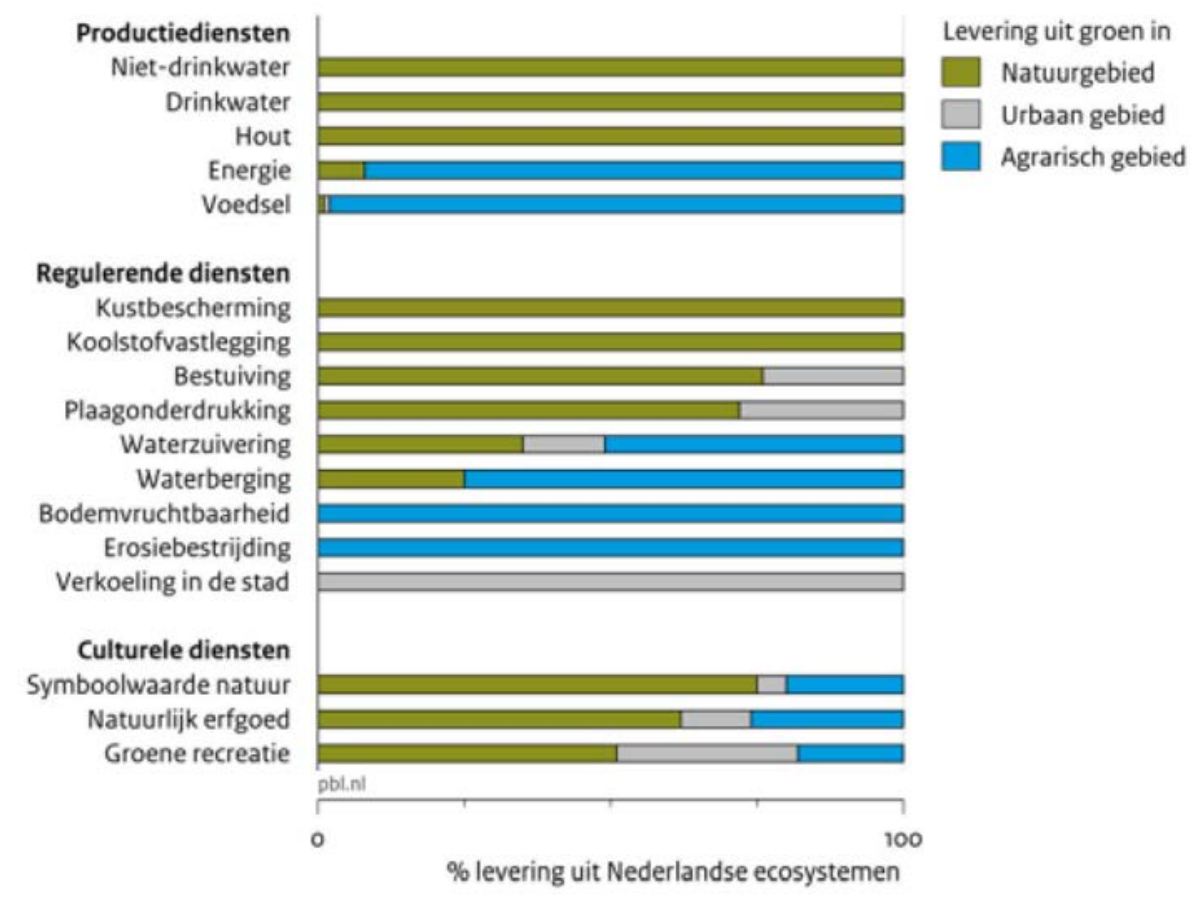

Bron: PBL; Alterra, Wageningen UR 2014

Figuur 4.1 Relatief belang van gebieden voor levering van goederen en diensten uit ecosystemen (De Knegt et al., 2014).

\subsection{Maatschappelijke vraag naar ecosysteemdiensten}

Voor veel ecosysteemdiensten is de trend in de afgelopen circa 25 jaar negatief door een combinatie van een afnemend aanbod en een groeiende vraag. De vraag naar ecosysteemdiensten wordt daarom vaak ingevuld met technische alternatieven of import vanuit het buitenland. Bij productiediensten gaat het vooral om import, zoals hout of vis. Bij regulerende en culturele diensten is import doorgaans geen optie, omdat de vraag naar een bepaalde dienst (behalve bij koolstofvastlegging) samenhangt met een bepaalde locatie. Daar kunnen technische alternatieven uitkomst bieden, zoals dijken in plaats van duinen of insecticiden in plaats van natuurlijke plaagbestrijders.

\section{Afnemend aanbod}

Vooral in het agrarisch gebied is het aanbod van veel ecosysteemdiensten, als gevolg van de overwegend intensieve landbouw, sterk verminderd (Figuur 4.2). Het organische stofgehalte van veel bodems is bijvoorbeeld afgenomen, wat ten koste gaat van ecosysteemdiensten zoals bodemvruchtbaarheid, koolstofvastlegging en het watervasthoudend vermogen. Dit werkt (wind)erosie in de hand. Hagen, houtwallen en natuurlijke oevers zijn geruimd of geminimaliseerd om o.a. grotere percelen te creëren, wat heeft geleid tot een afname van ecosysteemdiensten zoals natuurlijke plaagonderdrukking en bestuiving. Bodems worden gedraineerd, wat vooral in veenbodems heeft geleid tot oxidatie en daarmee $\mathrm{CO}_{2}$-uitstoot. De versnelde afvoer van water en de kanalisatie van beken hebben geleid tot een afname van de ecosysteemdienst waterberging, wat tijdens neerslagpieken kan leiden tot wateroverlast. De veelal monotone landbouwgebieden hebben bovendien tot een sterke afname van de biodiversiteit geleid en tot een verarming van de belevingswaarden voor de recreatie. Voorts zorgt de emissie uit de landbouw voor een negatief effect op de kwaliteit van natuurgebieden en het vermogen van deze gebieden om ecosysteemdiensten te kunnen leveren. 


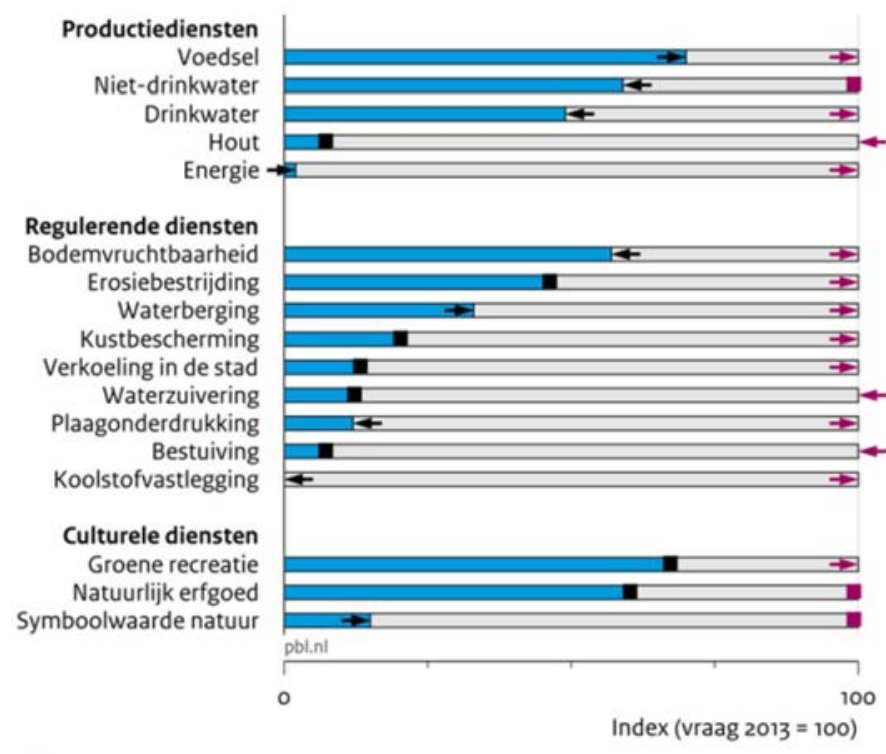

Afkomstig uit Nederlandse ecosystemen

Niet afkomstig uit Nederlandse ecosystemen (import/technisch alternatief/onvervuld)

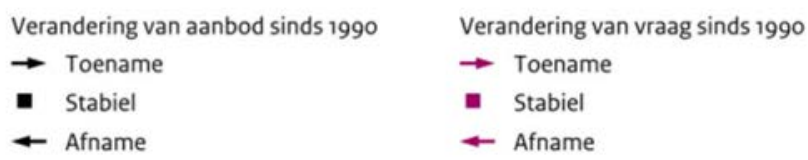

Bron: PBL; Alterra, Wageningen UR 2014

Figuur 4.2 Vraag en aanbod van ecosysteemdiensten (De Knegt et al., 2014).

\section{Groeiende vraag}

De toegenomen vraag naar ecosysteemdiensten kan vooral worden gekoppeld aan bepaalde trends, zoals klimaatverandering, bevolkingsgroei en vergrijzing. Door klimaatverandering zal de vraag naar ecosysteemdiensten zoals waterberging, kustbescherming, verkoeling in de stad, koolstofvastlegging en erosiebestrijding toenemen. Een groeiende bevolking en toename van vrije tijd als gevolg van vergrijzing zal leiden tot een toenemende vraag naar groene recreatie, vooral in de Randstad en enkele (grote) steden elders in het land waar nu al een tekort is aan groen.

Technische alternatieven om aan de groeiende vraag te voldoen, zijn vaak duur en monofunctioneel of in ieder geval veel minder multifunctioneel. Ze kunnen bovendien tot negatieve effecten op het milieu leiden, wat ook weer tot (zuiverings)kosten kan leiden. Bij de zoektocht naar mogelijke locaties voor robuuste natuur maken we gebruik van deze maatschappelijke vraag naar ecosysteemdiensten. Vraag en aanbod van een aantal ecosysteemdiensten worden momenteel in kaart gebracht (De Knegt et al., in prep.).

\subsection{Zoekgebieden voor robuuste natuurontwikkeling op basis van ecosysteemdiensten}

Indien het natuuroppervlak wordt uitgebreid (zie bijv. de taakstelling uit het Natuurpact: 80.000 ha nieuwe natuur ingericht), bijvoorbeeld door het verzilveren van de potenties voor robuuste natuur in Nederland, dan zullen naar verwachting ook de geleverde ecosysteemdiensten toenemen. Op het land gaat het dan vaak om de transformatie van agrarisch gebied in natuur of omvorming naar duurzame landbouw. Om na te gaan waar de grootste potenties liggen voor het realiseren van robuuste natuur in combinatie met ecosysteemdiensten, dienen de volgende vuistregels als leidraad. 
- Met de realisatie van robuuste natuur is in ruime mate sprake van een stapeling van ecosysteemdiensten, vooral diensten waar een grote lokale tot nationale maatschappelijke vraag naar is, nu en/of in de toekomst (zie ESD criteria en kaarten in Tabel 5.1).

- Geen wezenlijk negatieve effecten op bestaande gebruiksfuncties of op andere ecosysteemdiensten, bijvoorbeeld een hogere grondwaterstand die tot waterschade leidt aan onroerend goed (zie keerzijde Tabel 5.1).

- Kansen voor de lokale economie: de transformatie naar robuuste natuur leidt tot kansen voor de lokale economie, bijvoorbeeld via recreatie, $\mathrm{CO}_{2}$-handel, duurzame streekproducten etc. Vooral in gebieden waar de economie een stimulans kan gebruiken, zoals krimpgebieden (zie ook kaart krimp- en anticipeerregio's Tabel 5.1).

- Kansen technische alternatieven gering of afwezig: technische alternatieven voldoen niet aan de vraag, hebben nadelige neveneffecten of de kosten zijn te hoog. 


\section{$5 \quad$ Kansrijkdom voor robuuste natuur}

\subsection{Landelijke kaarten met criteria voor succesvolle robuuste natuur}

Bij de voorbeeldgebieden (hoofdstuk 3 ) is een aantal criteria genoemd waarom deze gebieden een succes zijn wat betreft robuuste natuur en natuurlijke processen en wat de randvoorwaarden en keerzijden zijn van deze natuur. De criteria daar genoemd, zijn bijeengebracht in Tabel 5.1. De gebieden van de best practices waar deze criteria gelden, zijn in de daarop volgende kolom aangegeven.

De criteria voor succes zijn verdeeld over de volgende rubrieken:

- Mogelijkheden voor natuurlijke processen.

- Uitgangssituatie (ruimtelijke variatie).

- Maatschappelijke opgaven en vraag naar ecosysteemdiensten (meekoppelkansen, incl. Klimaatverandering).

- Sociaal economische factoren.

- Keerzijde.

- Beheer (kosten).

- Biodiversiteit (haalbare doelen).

Een aantal ecosysteemdiensten (hoofdstuk 4) is belangrijk voor de meekoppelkansen en maatschappelijke opgaven. Deze criteria staan in Tabel 5.1 met de letters ESD als toevoeging.

Bij de criteria zijn vervolgens zo veel mogelijk landelijke kaarten gezocht die het betreffende criterium ruimtelijk weergeven of een benadering van het criterium ruimtelijk weergeven. Een criterium is bijvoorbeeld 'mogelijkheden voor beekdynamiek zoals overstroming' met als ruimtelijke weergave de stromende wateren op de waterkaart (van Puijenbroek \& Clement, 2010). Belangrijke GIS-bestanden die de verschillende criteria ruimtelijk weergeven, zijn bijvoorbeeld de landschappelijke bodemkaart (Van Delft et al., 2015), LGN7 (Hazeu et al., 2014), kwelkaart (NHI), kaarten van de klimaatcorridors (Vonk et al., 2010), een kaart met het ideale landschap van de gemiddelde Nederlander op basis van de ingevulde wensen van 35.000 websitebezoekers in 'Daar moet ik zijn' (Goossen et al., 2011), stromende wateren (van Puijenbroek \& Clement, 2010) en de kaarten behorende bij de graadmeter Diensten van Natuur (De Knegt et al., 2014 en De Knegt et al., in prep.). De bron van de gebruikte kaarten staat in Bijlage 2 en de gemaakte selecties van legenda-eenheden staan in Tabel 5.2.

Vooral in de rubrieken natuurlijke processen, de uitgangssituatie en maatschappelijk opgaven zijn kaarten beschikbaar. Van een aantal criteria zijn geen ruimtelijke gegevens voorhanden. Deze kunnen daarom niet worden meegewogen in de kansrijkdom. Sociaaleconomische factoren, zoals samenwerking en beheer(kosten), zijn ook niet altijd ruimtelijk specifiek. Ze staan echter wel in de Tabel omdat ze van doorslaggevend belang kunnen zijn. In een verdere uitwerking per gebied zouden deze criteria ook meegewogen moeten worden. Kaarten van de keerzijde, de nadelen van allerlei positieve factoren, zijn moeilijk mee te wegen. De nadelen moeten dan afgewogen worden tegen de voordelen op specifieke locaties, waardoor de weging van hoe zwaar factoren meetellen erg ingewikkeld wordt. Bijvoorbeeld de mate waarin problemen kunnen ontstaan door beveractiviteit is niet alleen afhankelijk van de verspreiding van de bevers, maar ook voornamelijk van de specifieke kenmerken van een locatie. Criteria voor de keerzijde zijn daarom alleen meegenomen als zij op nationaal niveau op kaart zijn te duiden, zoals infrastructuur. We gaan ervan uit dat nadelen op specifieke locaties grotendeels zijn te mitigeren (zie paragraaf 3.2).

Er zijn geen kaarten van de biodiversiteit (de doelen) meegenomen in de kansrijkdom-berekening. Deze criteria geven een beeld van effect van natuurontwikkeling op biodiversiteit en zouden dus geen onderdeel moeten zijn van het bepalen van de kansrijkdom, anders is er sprake van redundantie. De 
biodiversiteit als resultaat van de voorbeeldgebieden staat in Tabel 5.1. Deze resultaten geven een beeld van de mogelijkheden voor haalbare doelen.

Tabel 5.1 De criteria die effect hebben op de kansrijkdom van robuuste natuur op basis van de best practices (zie gebied) en de kaarten die het betreffende criterium ruimtelijk weergeven of een benadering van het criterium ruimtelijk weergeven. Van de lichtrode vakken zijn geen nationale kaarten voorhanden ( $D U=N H$ duinen; $G D=$ Geul dal; GP = Gelderse poort; HD = Hunze dal; OVP = Oostvaardersplassen; $V Z=$ Veluwezoom).

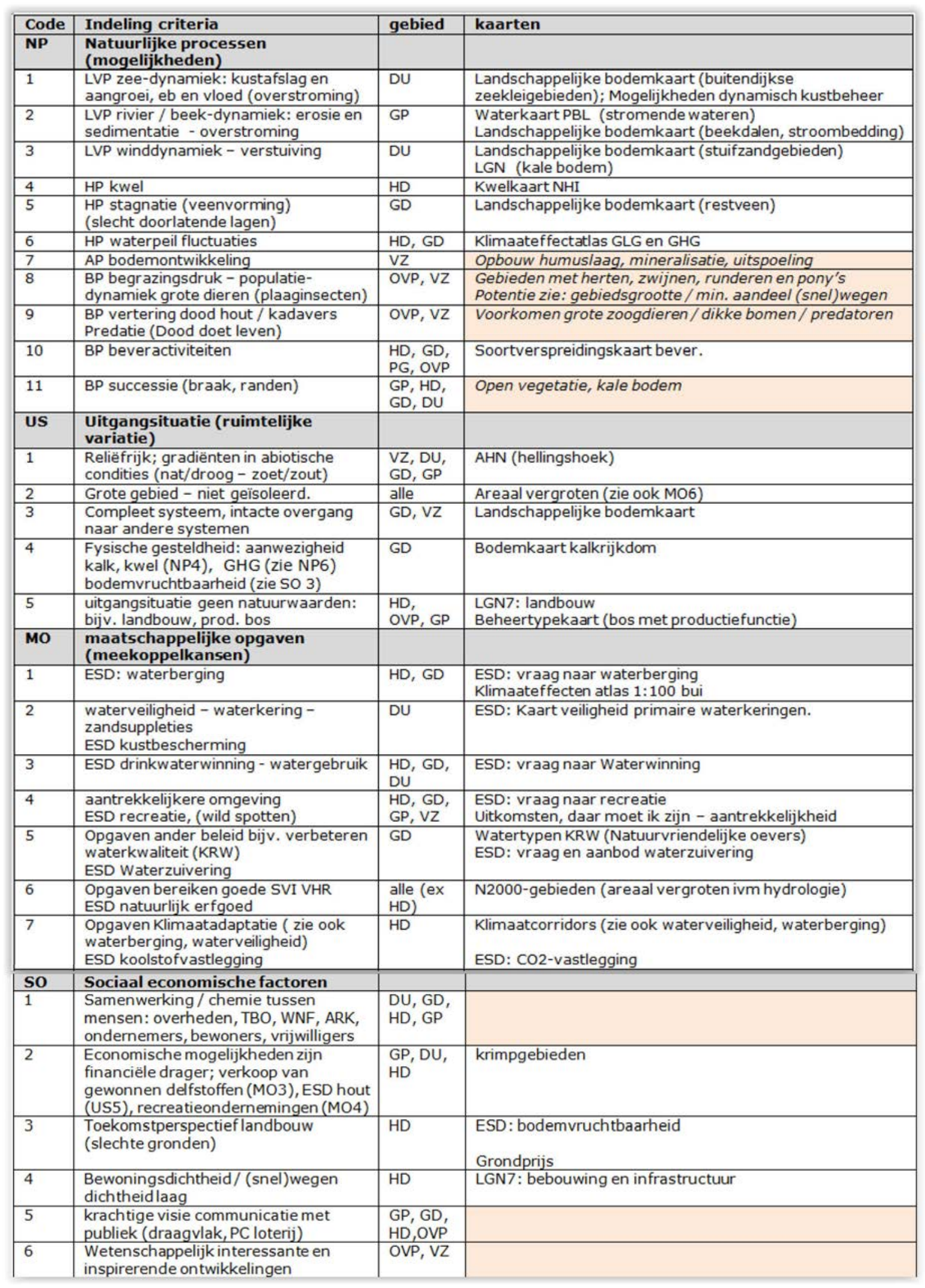




\begin{tabular}{|c|c|c|c|}
\hline KZ & Keerzijde & & \\
\hline 1 & $\begin{array}{l}\text { wateroverlast: natschade na herstel } \\
\text { hydrologie, beveractiviteiten }\end{array}$ & $\mathrm{DU}, \mathrm{GD}$ & $\begin{array}{l}\text { Keerzijde overstroming, waterpeilfluctuaties en voorkomen } \\
\text { bever bij stedelijke en productiegebieden }\end{array}$ \\
\hline 2 & $\begin{array}{l}\text { waterveiligheid: dichtgroeien } \\
\text { uiterwaarden met bos, beperkte } \\
\text { ruimte voor dynamiek }\end{array}$ & GP, DU & Keerzijde natuurlijke successie \\
\hline 3 & $\begin{array}{l}\text { verkeerveiligheid: aanrijding wild } \\
\text { faunaschade: regulering populatie }\end{array}$ & VZ & keerzijde grote zoogdieren bij wegen \\
\hline 5 & $\begin{array}{l}\text { Maatschappelijke weerstand } \\
\text { creperende dieren }\end{array}$ & OVP & keerzijde natuurlijke populatiedynamiek \\
\hline 6 & $\begin{array}{l}\text { Bestaande waarden verdwijnen: } \\
\text { kwetsbare soorten, cultuurhistorische } \\
\text { waarden, dichtgroeien openvegetaties }\end{array}$ & VZ, GD & $\begin{array}{l}\text { Beheertypenkaart (Kwetsbare beheertypen) } \\
\text { Cultuurhistorische en archeologische waardenkaart }\end{array}$ \\
\hline BK & Beheer (kosten) & & \\
\hline 4 & $\begin{array}{l}\text { aanvullend beheer (maaien }>> \\
\text { begrazen) }\end{array}$ & VZ & $\begin{array}{l}\text { ivm bestaande natuur en cultuurhistorische waarden die } \\
\text { anders verdwijnen }\end{array}$ \\
\hline BD & $\begin{array}{l}\text { biodiversiteit (kans op) / } \\
\text { haalbare doelen }\end{array}$ & & \\
\hline 1 & ontstaan soortenrijke vegetaties & DU, GD & \\
\hline 2 & $\begin{array}{l}\text { voorkomen grote diersoorten zoals } \\
\text { bever, otter }\end{array}$ & $\begin{array}{l}\mathrm{HD}, \mathrm{GD}, \\
\mathrm{PG}, \mathrm{OVP}\end{array}$ & \\
\hline 3 & $\begin{array}{l}\text { voorkomen moerasvogels, grote } \\
\text { roofvogels }\end{array}$ & OVP, HD & \\
\hline 4 & stroomminnende vissoorten & GD & \\
\hline
\end{tabular}

\subsection{Kaart met kansen voor ontwikkeling van robuuste natuur}

De verzamelde kaarten zijn met elkaar gecombineerd en op basis van de legenda-eenheden zijn de kansrijkdom-waarden berekend. Standaard hebben legenda-eenheden een waarde " 0 ". Als ze een positieve bijdrage leveren aan de kansrijkdom van robuuste natuur krijgen ze de waarde " 1 ". Als ze een negatieve bijdrage leveren aan de kansrijkdom de waarde " 1 ". Een negatieve waarde kan voorkomen als er veel infrastructuur of veel stedelijk gebied in de watersysteemeenheid aanwezig is. Ook zijn een hoge grondprijs, de aanwezigheid van kwetsbare natuurwaarden en/of cultuurhistorische waarden voor robuuste natuur negatief doorwerkende factoren. Robuuste natuur moet immers niet te veel geld kosten en ruimte krijgen voor ontwikkeling met zo min mogelijk beperkingen.

De onnauwkeurigheden in de begrenzing van GIS-kaarten (slivers en dergelijke) moeten zo min mogelijk doorwerken in de kansrijkdom. Om deze onnauwkeurigheden zo veel mogelijk uit te sluiten, moet het oppervlak van de waarden een minimumaandeel van de watersysteemeenheid uitmaken. Meestal is gekozen voor een minimaal oppervlak van $10 \%$, behalve als we denken dat een kleiner oppervlak van belang kan zijn voor robuuste natuur (zie laatste kolom Tabel 5.2). De waardenberekening voor de kansrijkdom staat in Tabel 5.2. Samengevat: de watersysteemeenheid kan per criterium een maximumwaarde 1 (zonder weging) krijgen mits de waarde op meer dan $10 \%$ van het areaal voorkomt. 
Tabel 5.2 Waardeberekening voor de bijdrage aan de kansrijkdom van de verschillende kaarten. Een afwijkende keuze voor minimumareaal en een negatieve weging voor robuuste natuur zijn geel gemarkeerd.

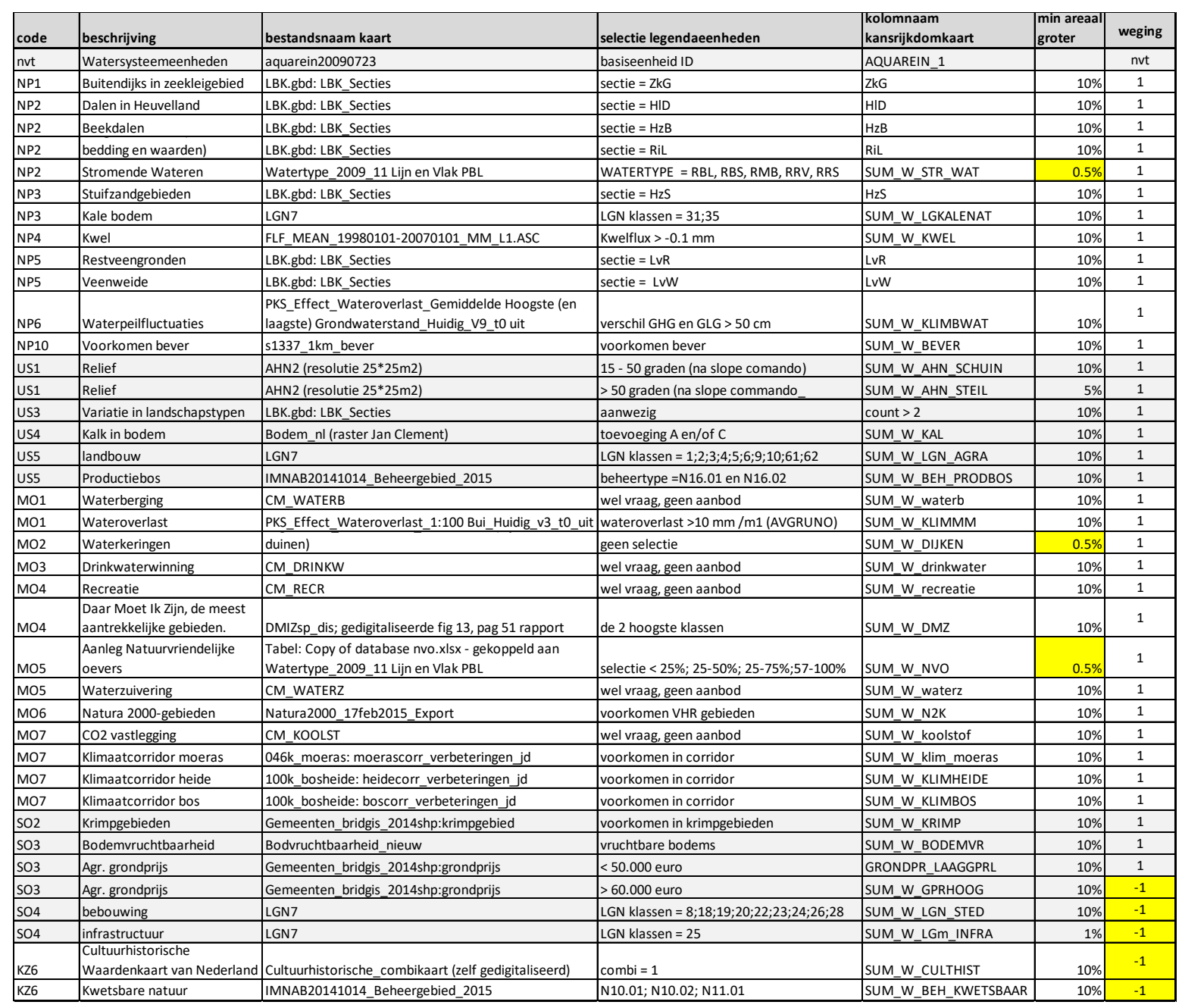

De waarden zijn vervolgens per watersysteemeenheid gesommeerd en deze gesommeerde waarde is vervolgens beoordeeld als een ongewogen relatieve maat voor de kansrijkdom. Met andere woorden: een hoge gesommeerde waarde betekent veel positieve criteria die bijdragen aan de ontwikkeling van robuuste natuur en dus een hoge kansrijkdom. De relatieve waarden per watersysteemeenheid staan in Figuur 5.1. Hierbij zijn de waarden samengenomen in 5 (Equal interval) klassen. De allerlaagste klasse is niet meegenomen, omdat sommige watersysteemeenheden voornamelijk bestaan uit grote wateren waarvan geen criteria-kaarten zijn meegenomen. Figuur 5.1 laat zien dat er veel kansen zijn voor robuuste natuur langs de grote rivieren, in beekdalsystemen, Drentsche Aa, Lunterse beek en in het binnenveld, langs de grote rivieren en enkele watersysteemeenheden in de Friese boezem. 


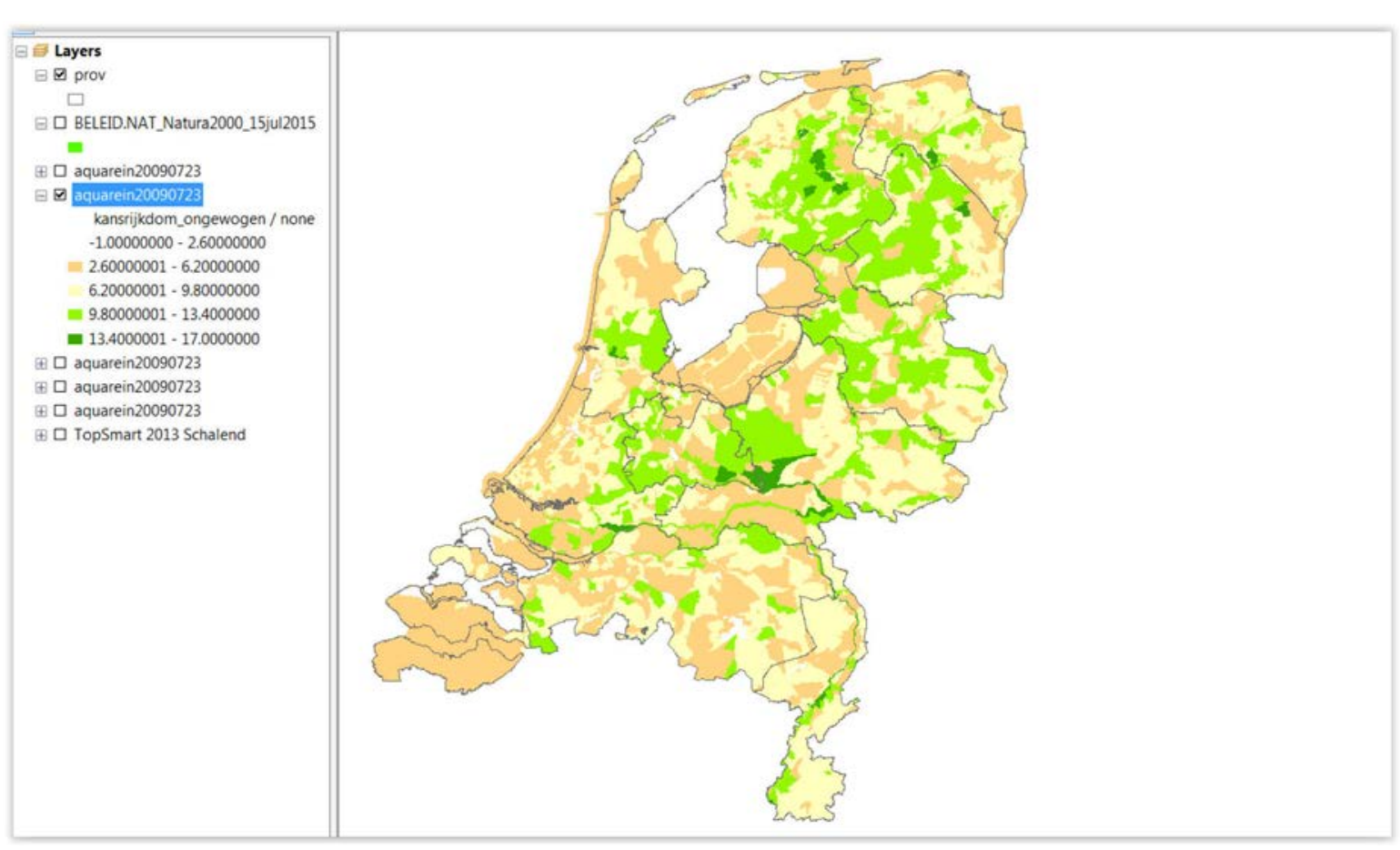

Figuur 5.1 Kansrijkdomkaart voor robuuste natuur. Alle criteria waar kaarten van zijn, tellen even zwaar mee. De waardeverdeling van de kansrijkdom heeft een relatieve schaal waarbij oranje staat voor het minst kansrijk en donkergroen voor het meest kansrijk. De watersysteemeenheden met de laagste waarden (-1 tot 2) zijn niet meegenomen omdat deze gebieden grotendeels samenvallen met locaties waarvan nauwelijks geschikte criteriakaarten beschikbaar waren, zoals de grote wateren.

De criteria zijn geselecteerd op basis van de best practices. Je zou verwachten dat deze gebieden een relatieve hoge kansrijkdom zouden krijgen, maar dat hoeft niet zo te zijn. Dit komt omdat het 1 . zeer verschillende gebieden zijn waar niet alle criteria gelden (zie kolom 'gebied' Tabel 5.1), 2. er ook criteria zijn die negatief doorwerken en de kansrijkdom deels teniet kunnen doen en 3 . omdat de criteriakaarten geheel onafhankelijk van het gebied zijn gemaakt op een nationale schaal. Omdat de kaarten onafhankelijk gemaakt zijn en omdat we informatie over de robuustheid van deze gebieden paraat hebben, kunnen we de resultaten bespreken aan de hand van de best practices: waarom krijgt een gebied wel of geen hoge kansrijkdom en welke criteria ontbreken wel of niet terecht op de beschikbare kaarten?

Een van de mogelijke verklaringen (2) waarom een voorbeeldgebied geen hoge kansrijkdom heeft, is dat deze deels tenietgedaan kan worden door negatief doorwerkende criteria (zie kolom 'weging' Tabel 5.2). Zo wordt de aanwezigheid van infrastructuur, cultuurhistorische waarden en kwetsbare natuur negatief gewogen in de kansrijkdom van robuuste natuur. In Tabel 5.3 staan de watersysteemeenheden van de best practices en deze negatief doorwerkende criteria. 
Tabel 5.3 Watersysteemeenheden best practice-gebieden en de negatief doorwerkende criteria die de kansrijkdom deels tenietdoen ( $D U=N H$ duinen; $G D=G e u l$ dal; $G P=$ Gelderse poort; $H D=$ Hunzedal; OVP = Oostvaardersplassen; VZ= Veluwezoom).

\begin{tabular}{|c|c|c|c|c|c|c|c|c|c|c|c|}
\hline gebied & OBJECTID & AQUAREIN & WATERSCHAP & opp (ha) & $\begin{array}{l}\text { kansrijkd } \\
\text { om_onge } \\
\text { wogen }\end{array}$ & $\begin{array}{l}\text { negatieve } \\
\text { bijdrage }\end{array}$ & \begin{tabular}{|l} 
SUM_W_ \\
LGN_STE \\
D
\end{tabular} & $\begin{array}{l}\text { SUM_W_ } \\
\text { CULTHIST }\end{array}$ & $\begin{array}{l}\text { SUM_W_ } \\
\text { LGm_INF } \\
\text { RA }\end{array}$ & \begin{tabular}{|l|} 
SUM_W_- \\
BEH_KWE \\
TSBAAR \\
\end{tabular} & \begin{tabular}{|l|} 
SUM_W_- \\
GPRHOO \\
G \\
\end{tabular} \\
\hline $\mathrm{DU}$ & 592 & Niet toegekend & Hollands Noorde & 5761 & 6 & -1 & 0 & -1 & 0 & 0 & 0 \\
\hline GD & 222 & Geul & Roer en Overmaa & 8954 & 8 & -4 & -1 & -1 & -1 & 0 & -1 \\
\hline GP & 231 & Niet toegekend & Water & 2904 & 14 & -1 & 0 & -1 & 0 & 0 & 0 \\
\hline GP & 241 & Niet toegekend & Water & 1146 & 13 & 0 & 0 & 0 & 0 & 0 & 0 \\
\hline GP & 255 & Niet toegekend & Water & 1337 & 14 & -1 & 0 & -1 & 0 & 0 & 0 \\
\hline $\mathrm{HD}$ & 332 & Hunze & Hunze en Aa's & 1522 & 5 & -2 & 0 & -1 & -1 & 0 & 0 \\
\hline $\mathrm{HD}$ & 333 & Hunze & Hunze en Aa's & 2623 & 13 & -2 & 0 & -1 & -1 & 0 & 0 \\
\hline $\mathrm{HD}$ & 334 & Hunze & Hunze en Aa's & 3199 & 10 & -3 & -1 & -1 & -1 & 0 & 0 \\
\hline $\mathrm{HD}$ & 335 & Hunze & Hunze en Aa's & 2142 & 9 & -1 & 0 & -1 & 0 & 0 & 0 \\
\hline $\mathrm{HD}$ & 825 & Hunze & Hunze en Aa's & 3880 & 10 & -2 & -1 & -1 & 0 & 0 & 0 \\
\hline OVP & 2397 & Flevoland-Lage afdelin & Zuiderzeeland & 6970 & 6 & -3 & -1 & 0 & -1 & 0 & -1 \\
\hline $\mathrm{VZ}$ & 554 & Zuid-Veluwe & Rijn en IJssel & 7728 & 8 & -3 & -1 & -1 & -1 & 0 & 0 \\
\hline
\end{tabular}

Uit de resultaten blijkt dat de kansrijkdom voor robuuste natuur van de voorbeeldgebieden sterk varieert. De Gelderse poort is volgens de gevolgde methode zeer kansrijk voor robuuste natuur, terwijl de Oostvaardersplassen dit niet zijn. Vooral in het Geuldal wordt de kansrijkdom deels tenietgedaan door aanwezige infrastructuur, cultuurhistorie e.d. De geel gemarkeerde waarden in Tabel 5.3 komen niet overeen met wat we verwachten. Waarom telt bijvoorbeeld kwetsbare natuur niet mee in de duinen? Er is wel kwetsbare natuur aanwezig in de duinen van NH en in het Geuldal, alleen die kwetsbare beheertypen op de beheertypenkaart hebben een areaal van minder dan $10 \%$ van deze gebieden. In het Hunzedal is veel cultuurhistorie aanwezig en staat op de Belvedere-kaarten als 'gebieden met hoge archeologische waarden'. In de Oostvaardersplassen en de Veluwezoom werkt stedelijk gebied negatief door op de mogelijkheden voor robuuste natuur, omdat de begrenzing van de watersysteemeenheid groter is dan alleen het natuurgebied en een deel van de naastgelegen steden omvat.

\subsection{Weging van belangen}

De kansrijkdomkaart in paragraaf 5.2 is tot stand gekomen door alle criteria even zwaar te wegen. Door een of enkele criteria een hogere waarde te geven, kunnen verschillende belangen een hogere prioriteit krijgen. De bijdrage van de criteria voor klimaat, ecosysteemdiensten en natuurlijke processen wordt besproken in paragraaf 5.3.1. De mogelijkheden voor het meekoppelen met het verbeteren van de watercondities en aanvullende robuuste natuur rondom Natura 2000-gebieden staan in paragraaf 5.3.2.

\subsubsection{Meekoppelen met klimaat, ecosysteemdiensten en natuurlijke processen}

Onder klimaatbestendige robuuste natuur verstaan we natuur die bijdraagt aan ecosysteemdiensten, zoals waterberging en waterveiligheid (waterkeringen). Maar ook natuur waar soorten kunnen overleven wanneer het klimaat verandert door te migreren binnen klimaatcorridors voor moeras, heide en bos en door reliëf waar soorten langs kunnen bewegen op zoek naar een beter leefgebied als het ze te koud, warm, nat of droog onder hun voeten of wortels is geworden. Hierdoor wordt lokaal uitsterven vermeden. In deze weging van belangen tellen we alleen deze laatste (klimaatcorridors en reliëf) criteria dubbel. De ecosysteemdiensten waterberging en waterveiligheid tellen bij de weging van ecosysteemdiensten mee. Het resultaat staat in Figuur 5.2.

Figuur 5.2 laat zien dat er veel kansen zijn voor robuuste klimaatbestendige natuur, maar ook voor locaties met vraag naar ecosysteemdiensten en potenties voor natuurlijke processen, zoals langs de grote rivieren (Maas, Gelderse poort en IJsseldelta), in beekdalsystemen, Drentsche Aa en MiddenDrenthe, de Lunterse beek, rondom Wageningen en in de Gelderse vallei en enkele watersysteemeenheden van de Friese boezem. In meer of mindere mate zijn het veelal dezelfde gebieden die kansrijk zijn. 

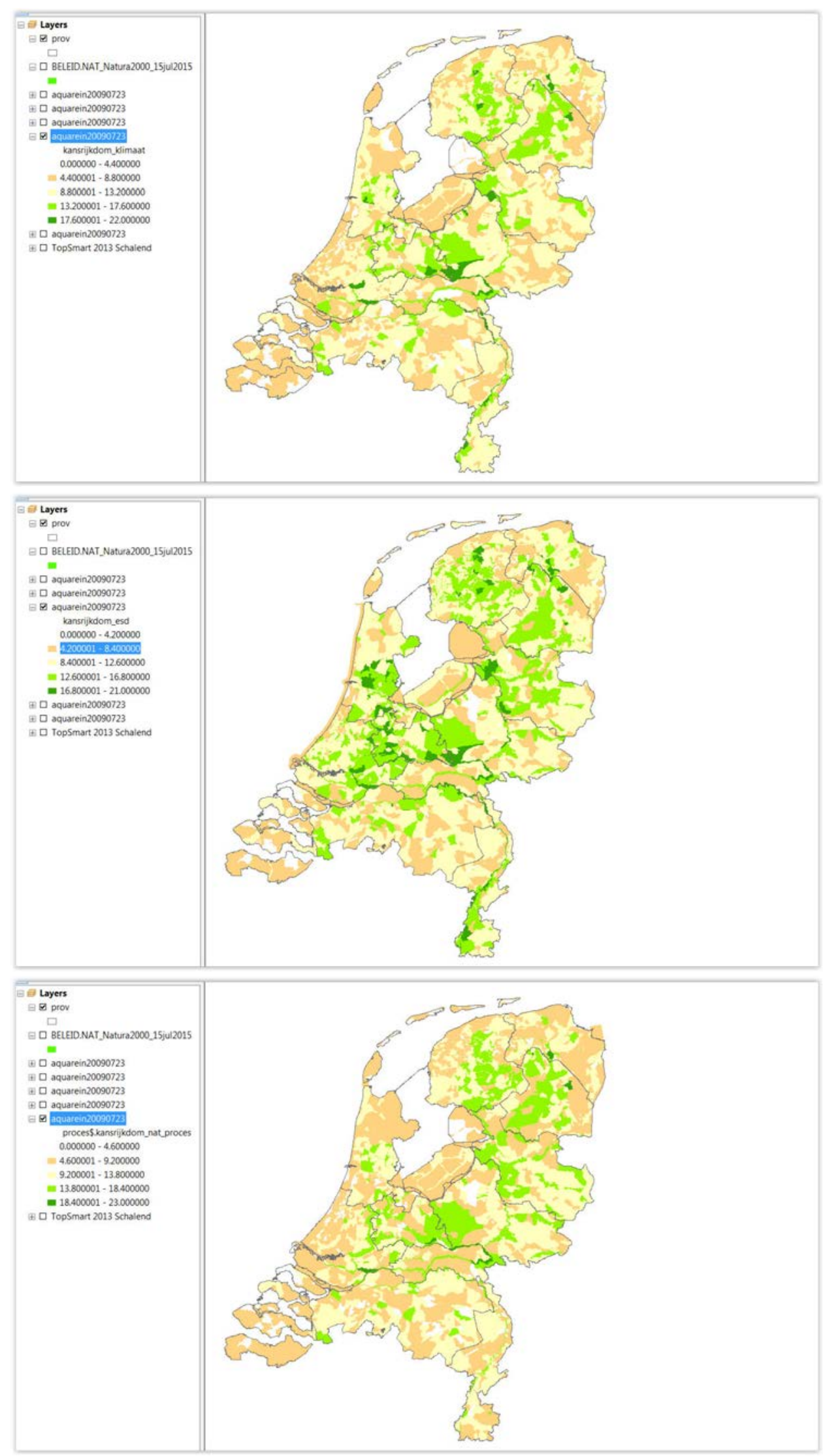

Figuur 5.2 Kansrijkdomkaart voor klimaatbestendige robuuste natuur (boven), robuuste natuur met ecosysteemdiensten (midden) of natuurlijke processen (onder). De waardeverdeling van de kansrijkdom heeft een relatieve schaal waarbij oranje staat voor het minst kansrijk en donkergroen voor het meest kansrijk. 
Ook hier gebruiken we de voorbeeldgebieden om inzicht te krijgen in de niet verwachte verschillen in kansrijkdom tussen gebieden: waarom krijgt een gebied wel of geen hoge kansrijkdom en welke criteria ontbreken wel of niet terecht op de beschikbare kaarten? Opvallend is dat een aantal gebieden niet hoog scoort, zoals het duingebied en de Oostvaardersplassen, waarvan je dat wel zou verwachten op basis van de best practice-keuze. Voor het duingebied ontbreken criteriakaarten die met de zeedynamiek te maken hebben. Om hieraan te voldoen, zouden aanvullende criteriakaarten moeten worden gezocht of gemaakt. De gebruikte kaart met primaire waterkeringen (CBS et al., 2014; Inspectie Leefomgeving en Transport, 2013) blijkt in zijn huidige vorm niet geschikt. De kaart zelf is namelijk een lijnenkaart en grote delen van de kustlijn bleken net buiten de watersysteemeenheden te liggen. Een alternatief voor een vervolg zou zijn de watersysteemeenheden die grenzen aan de primaire waterkering te selecteren en deze alle een waarde te geven voor kustveiligheid.

Ook de Oostvaardersplassen zijn volgens de gebruikt methode weinig kansrijk voor robuuste natuur. De Oostvaardersplassen krijgen weinig punten voor ecosysteemdiensten, natuurlijke processen en klimaatrobuustheid. Dit komt onder andere omdat er geen criteriakaarten van de begrazingsprocessen beschikbaar zijn. Ook is het gebied weinig variabel wat betreft reliëf, de variatie in (aantal) aanwezige ecosecties en er zijn verder weinig meekoppelkansen.

Ook bij de overige best practice-gebieden staan resultaten die niet direct verwacht zijn. Zo staat in Tabel 5.4 dat de Veluwezoom niet meer dan 2 (count $>2$ ) ecosecties heeft. De watersysteemeenheid van de Veluwezoom heeft wel meerdere ecosecties, maar de meeste hebben een areaal dat kleiner is dan $10 \%$ van de watersysteemeenheid. Delen van het Hunzedal blijken onderdeel uit te maken van de klimaatcorridor heide en de klimaatcorridor bos. De watersysteemeenheden van het Hunzedal bevatten dus niet alleen het dal zelf, maar ook de hogere inzijggebieden die onderdeel zijn van het bos en heide-klimaatcluster.

Uit Tabel 5.5 blijkt dat de duinen in Noord-Holland geen punten krijgen voor de ecosysteemdiensten waterveiligheid (dijken), recreatie en drinkwaterwinning. De duinen leveren juist een heel hoge bijdrage aan waterveiligheid, recreatie en drinkwaterwinning. De knegt et al. (in prep.) brengen in kaart waar vraag en aanbod van de ecosysteemdiensten wel of niet in overeenstemming zijn. Het aanbod van deze diensten is volgens de methode groter dan de vraag, waardoor er dus geen aanvullende vraag is. Juist waar de vraag groter is dan het aanbod zijn er kansen voor ontwikkeling van robuuste natuur. Hoewel de levering van ecosysteemdiensten groot kan zijn, gaat het dus vooral om het aanbod ten opzichte van de vraag die de kansrijkdom bepaalt.

In de watersysteemeenheid van de Veluwezoom blijkt ook vraag naar diensten te zijn voor waterberging en waterveiligheid. De watersysteemeenheid omvat niet alleen een deel van de stuwwal, maar ook de overgang naar de rivier.

Kaarten van potentiële natuurlijke processen zijn vooral gebaseerd op aanwezigheid van stromend water of van landschappelijke eenheden (ecosecties) die zijn ontstaan door deze processen in het verleden. Uit Tabel 5.6 blijkt dat de beekdalgronden in enkele watersysteemeenheden in het Hunzedal en de stuifzandgebieden in de Veluwezoom niet meetellen, omdat ze een oppervlak van minder dan $10 \%$ van het areaal van de watersysteemeenheid omvatten. Ook de kale bodem in de duinen van Noord-Holland heeft een kleiner areaal dan $10 \%$ van de watersysteemeenheid. Mogelijk is deze eis van minimaal $10 \%$ van het areaal te streng en past een lager percentage bij een aantal criteria beter. 
Tabel 5.4 Watersysteemeenheden best practice-gebieden en de criteria voor klimaat $(D U=N H$ duinen; $G D=$ Geuldal; $G P=$ Gelderse poort; $H D=$ Hunzedal; OVP = Oostvaardersplassen; VZ= Veluwezoom). Een beschrijving van de kolomnamen van de genoemde criteria staat in tabel 5.2.

\begin{tabular}{|c|c|c|c|c|c|c|c|c|c|c|c|c|}
\hline gebied & OBJECTID & AQUAREIN & WATERSCHAP & opp (ha) & $\begin{array}{l}\text { kansrijkd } \\
\text { om_onge } \\
\text { wogen } \\
\end{array}$ & \begin{tabular}{|l} 
bijdrage \\
klimaat
\end{tabular} & count $>2$ & $\begin{array}{l}\text { SUM_W_ } \\
\text { KLIMBOS } \\
\end{array}$ & $\begin{array}{l}\text { SUM_W_ } \\
\text { klim_moe } \\
\text { ras }\end{array}$ & \begin{tabular}{|l} 
SUM_W_ \\
KLIMHEID \\
E
\end{tabular} & $\begin{array}{l}\text { SUM_W_ } \\
\text { AHN_SCH } \\
\text { UIN }\end{array}$ & $\begin{array}{l}\text { SUM_W_ } \\
\text { AHN_STEI } \\
\text { L }\end{array}$ \\
\hline DU & 592 & Niet toegekend & Hollands Noorde & 5761 & 6 & 3 & 1 & 0 & 0 & 0 & 1 & 1 \\
\hline GP & 231 & Niet toegekend & Water & 2904 & 14 & 2 & 0 & 0 & 1 & 0 & 1 & 0 \\
\hline GP & 241 & Niet toegekend & Water & 1146 & 13 & 2 & 0 & 0 & 1 & 0 & 1 & 0 \\
\hline GP & 255 & Niet toegekend & Water & 1337 & 14 & 2 & 0 & 0 & 1 & 0 & 1 & 0 \\
\hline $\mathrm{HD}$ & 334 & Hunze & Hunze en Aa's & 3199 & 10 & 2 & 0 & 0 & 1 & 1 & 0 & 0 \\
\hline $\mathrm{HD}$ & 335 & Hunze & Hunze en Aa's & 2142 & 9 & 1 & 0 & 0 & 1 & 0 & 0 & 0 \\
\hline $\mathrm{HD}$ & 825 & Hunze & Hunze en Aa's & 3880 & 10 & 3 & 1 & 1 & 0 & 0 & 1 & 0 \\
\hline OVP & 2397 & Flevoland-Lage afdelin & Zuiderzeeland & 6970 & 6 & 1 & 0 & 0 & 1 & 0 & 0 & 0 \\
\hline VZ & 554 & Zuid-Veluwe & Rijn en IJssel & 7728 & 8 & 3 & 0 & 1 & 0 & 1 & 1 & 0 \\
\hline
\end{tabular}

Tabel 5.5 Criteria best practice-gebieden voor ecosysteemdiensten.

\begin{tabular}{|c|c|c|c|c|c|c|c|c|c|c|c|c|c|c|}
\hline gebied & OBJECTID & AQUAREIN & WATERSCHAP & opp (ha) & \begin{tabular}{|l|} 
kansrijkd \\
om_onge \\
wogen
\end{tabular} & \begin{tabular}{|l|} 
Bijdrage \\
ESD
\end{tabular} & $\begin{array}{l}\text { SUM_W_ } \\
\text { DIJKEN }\end{array}$ & $\begin{array}{l}\text { SUM_W_ } \\
\text { waterb }\end{array}$ & $\begin{array}{l}\text { SUM_W } \\
\text { recreatie }\end{array}$ & \begin{tabular}{|l|} 
SUM_W \\
DMZ
\end{tabular} & $\begin{array}{l}\text { SUM_W_ } \\
\text { koolstof }\end{array}$ & $\begin{array}{l}\text { SUM_W_ } \\
\text { drinkwate } \\
r\end{array}$ & $\begin{array}{l}\text { SUM_W_ } \\
\text { waterz }\end{array}$ & $\begin{array}{l}\text { SUM_W } \\
\text { KLIMMM }\end{array}$ \\
\hline $\mathrm{DU}$ & 592 & Niet toegekend & Hollands Noorde & 5761 & 6 & 2 & 0 & 0 & 0 & 1 & 0 & 0 & 0 & 1 \\
\hline GD & 222 & Geul & Roer en Overmaz & 8954 & 8 & 2 & 0 & 0 & 0 & 1 & 0 & 0 & 1 & 0 \\
\hline GP & 241 & Niet toegekend & Water & 1146 & 13 & 2 & 1 & 1 & 0 & 0 & 0 & 0 & 0 & 0 \\
\hline GP & 255 & Niet toegekend & Water & 1337 & 14 & 4 & 1 & 1 & 0 & 1 & 0 & 0 & 0 & 1 \\
\hline $\mathrm{HD}$ & 332 & Hunze & Hunze en Aa's & 1522 & 5 & 1 & 0 & 0 & 0 & 1 & 0 & 0 & 0 & 0 \\
\hline $\mathrm{HD}$ & 335 & Hunze & Hunze en Aa's & 2142 & 9 & 3 & 0 & 0 & 0 & 1 & 0 & 1 & 0 & 1 \\
\hline $\mathrm{HD}$ & 825 & Hunze & Hunze en Aa's & 3880 & 10 & 2 & 0 & 0 & 0 & 1 & 1 & 0 & 0 & 0 \\
\hline OVP & 2397 & Flevoland-Lage afdelin & Zuiderzeeland & 6970 & 6 & 4 & 0 & 1 & 0 & 1 & 0 & 0 & 1 & 1 \\
\hline $\mathrm{VZ}$ & 554 & Zuid-Veluwe & Rijn en IJssel & 7728 & 8 & 4 & 1 & 1 & 0 & 1 & 0 & 0 & 0 & 1 \\
\hline
\end{tabular}

Tabel 5.6 Criteria best practice-gebieden voor proces.

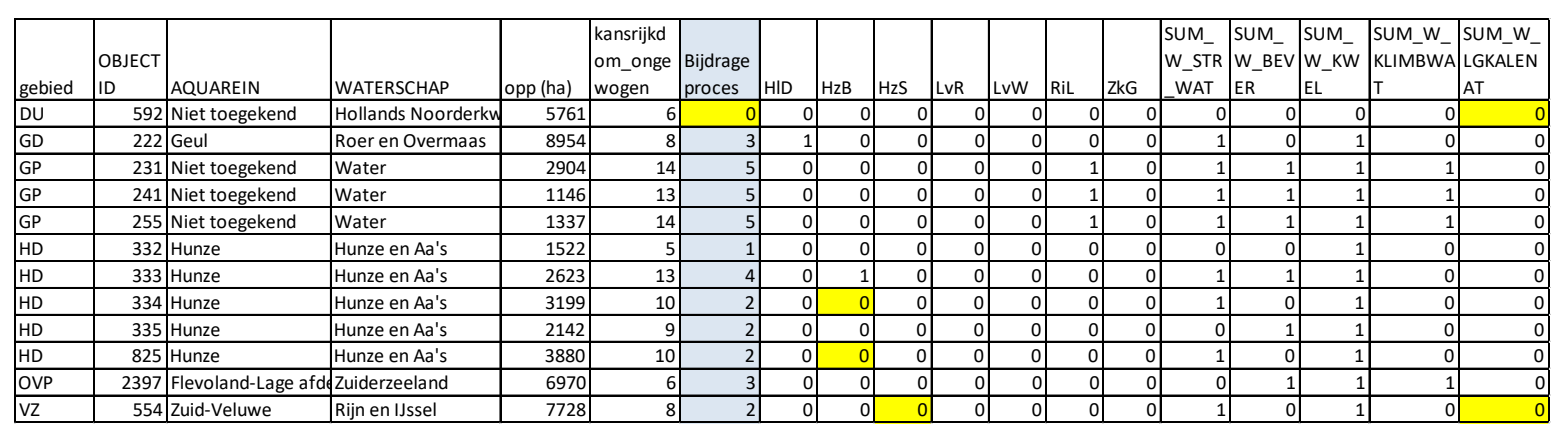




\subsubsection{Meekoppelen met Natura2000}

Wanneer er maar een deel van het areaal van een watersysteemeenheid Natura 2000-gebied is, verwachten we dat het moeilijker is om watermaatregelen te nemen dan wanneer de hele watersysteemeenheid Natura 2000-gebied is. Ontwikkeling van robuuste natuur kan een bijdrage leveren aan een goede Staat van Instandhouding in deze eenheden met een aandeel door een bijdrage te leveren aan de benodigde ruimte voor hydrologische maatregelen. Ook andersom zijn er kansen: de robuuste natuur gelegen naast Natura2000-gebieden kan profiteren van de nabijheid (brongebied van soorten) van natuur met een hoge biodiversiteit en van de maatregelen die daar worden genomen. De hydrologische eenheden die overlappen maar gedeeltelijk buiten de Natura2000gebieden liggen, staan in Figuur 5.3.

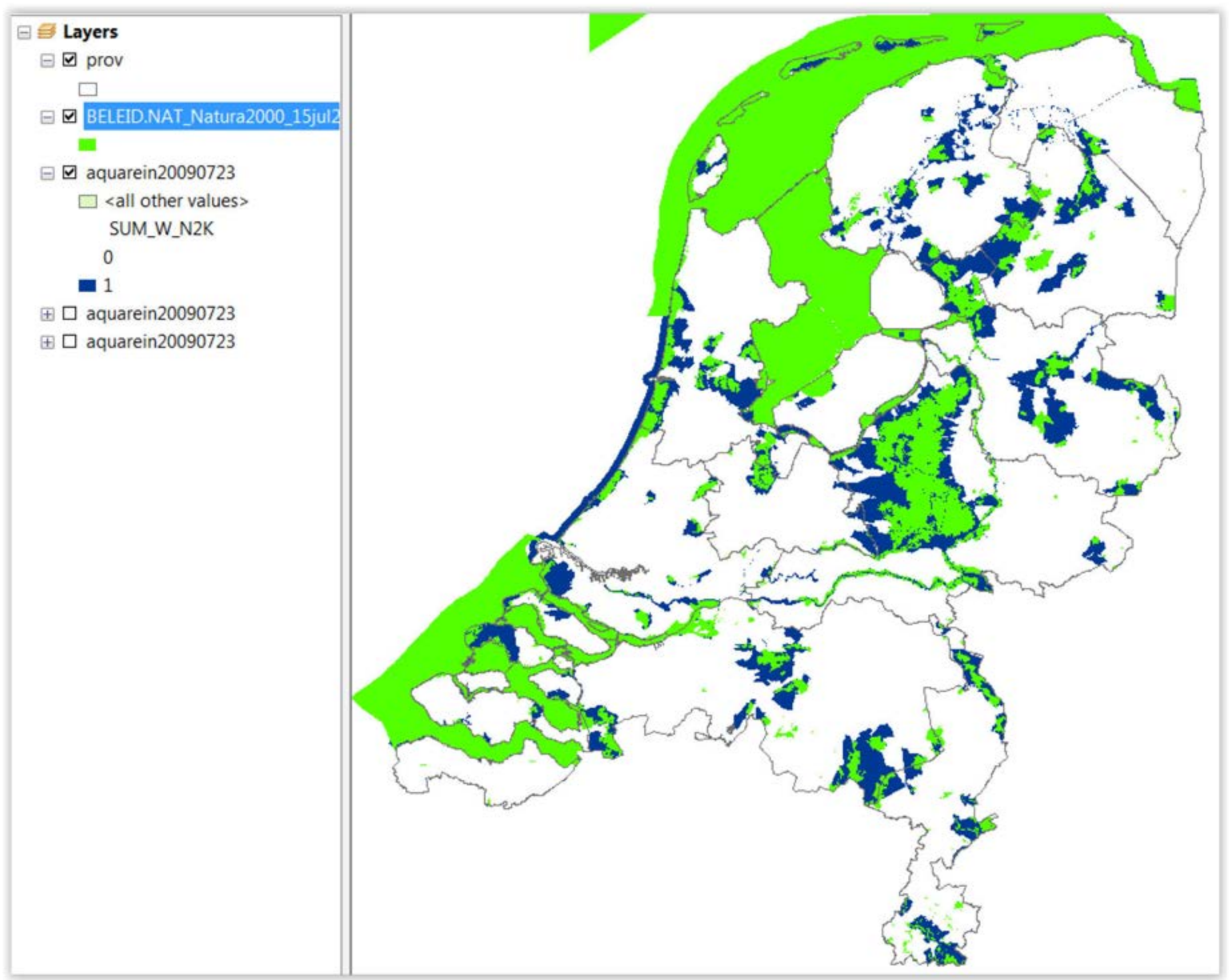

Figuur 5.3 Ontwikkeling van robuuste natur in watersysteemeenheden (blauw) die gedeeltelijk overlappen met Natura 2000-gebieden (groen) zijn kansrijk voor het leveren van een bijdrage aan herstel en behoud van natuurwaarden in die Natura 2000-gebieden. 


\section{Discussie en conclusies}

\subsection{Geen vaste definitie voor robuuste natuur}

Onder robuuste natuur verstaat men in de Rijksnatuurvisie (EZ, 2014a) een veerkrachtige toekomstbestendige natuur met lage beheerlasten (1) en haalbare doelen (2), die maximaal aansluit bij natuurlijke processen (3), die op natuurlijke wijze kan meebewegen met veranderende omstandigheden zoals door het klimaat (4) en die de invloed van de samenleving kan verdragen en daar bij kan gedijen (5).

Voorafgaand aan de Rijksnatuurvisie dacht men in het beleid bij de term robuuste natuur vooral aan het vergroten van gebieden en niet zozeer op het vergroten van natuurlijkheid of een van de andere genoemde kenmerken. In het Natuurpact (EL\&I, 2013) bijvoorbeeld wordt de term robuust alleen gebruikt als kenmerk van het Natuurnetwerk in relatie tot het vergroten van bestaande natuurgebieden. In grote eenheden natuur is vervolgens wel meer ruimte voor natuurlijke processen (PBL, 2007). Inmiddels wordt robuustheid ook geassocieerd met lage beheerkosten en daarom met zelfredzaamheid en natuurlijkheid. Eerder werden deze termen geassocieerd met grootschalige dynamische natuur, maar die blijkt op maar weinig plaatsten haalbaar in Nederland. Uitgangspunt bij terreinbeheerders is echter niet 'natuurlijkheid' maar 'natuurlijker'. Beheerders wegen natuurlijkheid af ten opzichte van bestaande waarden, beoogde functies en doelen. Waar zij dat wenselijk achten, wordt het beheer aangepast. Natuurlijker is dus niet per definitie synoniem aan lage of lagere beheerkosten. Hieruit blijkt dat de ideeën uit de natuurvisie nog geen gemeengoed zijn en vragen om nadere concretisering.

Op basis van de bovenstaande karakteristieken kunnen we robuuste natuur positioneren tussen grootschalige, half-natuurlijke en multifunctionele natuur (Figuur 6.1). Ten opzichte van grootschalige dynamische natuur of wildernisnatuur is robuuste natuur volgens de criteria veel minder gevoelig voor menselijk medegebruik. Ten opzichte van half-natuurlijke natuur wordt in robuuste natuur minder intensief beheerd voor behoud van biodiversiteit of van cultuurlandschappen. Ten opzichte van multifunctionele natuur wordt er meer gebruikgemaakt van natuurlijke processen en is het medegebruik niet dominant. Omdat kwetsbare natuurwaarden verloren kunnen gaan bij de ontwikkeling van robuuste natuur is de verwachting dat de biodiversiteit in het algemeen wat minder groot is dan bij grootschalige dynamische natuur of bij de op biodiversiteitgerichte beheer van de halfnatuurlijke natuur.

Robuuste natuur is hiermee gepositioneerd, maar nog niet gedefinieerd en 'strak omlijnd'. Een definitie mag dan de verwarring verminderen en het discussie scherpen; een te strakke omlijning werkt beperkend en daarmee contraproductief. Pluriformiteit is in dit geval juist een kracht. Uiteindelijk bepalen de criteria voor 'succes' wat we onder robuuste natuur in Nederland verstaan. 


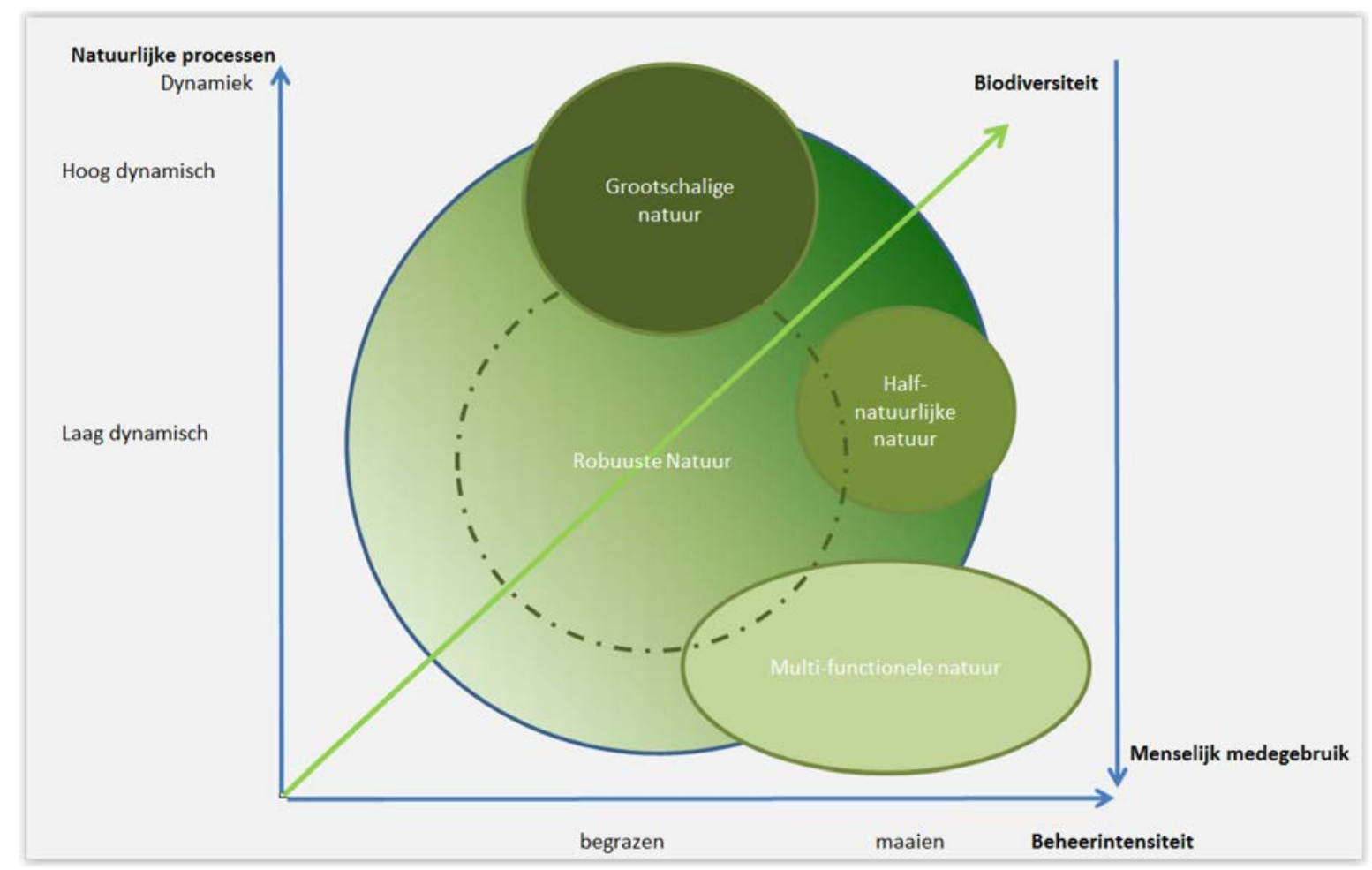

Figuur 6.1 Positie robuuste natuur t.o.v. grootschalige, half-natuurlijke en multifunctionele natuur.

\subsection{Een robuuste methode voor kansrijke locaties}

\section{Representativiteit criteria voor succes uit best practices}

De keuze voor de best practices is gebaseerd op bestaande natuurgebieden die het projectteam als robuust beschouwt. Omdat de gebieden de criteria voor succes leveren, hebben we een zo breed mogelijke range aan gebieden gekozen. We hebben daarom niet alleen gelet op de veronderstelde robuustheid, maar ook op de spreiding over Nederland, de mate van het optreden van dynamiek en natuurlijke processen, de periode van ontwikkeling e.d. Door de brede basis van verschillende best practice-gebieden en de verdeling van de criteria over de kenmerken van robuuste natuur uit de natuurvisie, menen we dat we een robuuste set aan criteria hebben gevonden. Ook de brede gebiedskeuze heeft echter zijn beperkingen. De consequentie van de keuze voor deze methode is dat alle criteria even zwaar wegen. In een vervolgonderzoek zouden we, ter toetsing van de criteria, een aantal terreinbeheerders en provinciale beleidsmedewerkers hun Top5 meest robuuste natuurgebieden in Nederland kunnen laten noemen. Hiermee kan dan het belang van de criteria voor robuustheid worden gegeven op basis van de volgorde waarin zij de gebieden noemen en het aantal gebieden waarvoor een criterium als succesfactor wordt genoemd. We weten dan welke criteria de hoogste prioriteit hebben. Deze methode geeft ook inzicht in de verschillen in beelden over robuuste natuur van onderzoekers, terreinbeheerders en provinciale medewerkers. In een vervolgonderzoek zouden we ook nog kunnen kijken naar het tegenovergestelde: welke gebieden vinden we helemaal niet robuust? Ook deze gebieden kunnen inzicht geven in relevante criteria.

\section{Beschikbare kaarten representatief voor criteria}

Bij de criteria zijn de best beschikbare landelijke kaarten (GIS-bestanden) gezocht. Niet altijd zijn dit kaarten van de criteria zelf, maar van onderwerpen die ermee samenhangen. Zo zijn de natuurlijke processen niet op kaart beschikbaar, maar geeft de landschappelijke bodemkaart wel de potentieel mogelijke ruimtelijke spreiding van deze processen, omdat ze in het verleden de bodem en geomorfologie bepaald hebben. Ook ligt er een aantal interpretaties aan de basis van de kaarten met 'de vraag' naar de ecosysteemdiensten (zie De Knegt et al., in prep.). 
De kaarten van andere criteria, zoals de uitgangssituatie (LGN), reliëf (AHN), verspreiding bever, cultuurhistorie en natura2000-gebieden geven wel een direct ruimtelijk patroon van de criteria en er zijn landsdekkend beschikbaar. De kaarten zijn echter vaak van verschillende schaal en detailniveau. Door de watersysteemeenheid als de minimale kaarteenheid te nemen, wordt de schaal naar deze eenheid aangepast. Voor kaarten op regioniveau, zoals de grondprijs, zijn geen gegevens beschikbaar op het niveau van de watersysteemeenheid. De lokale variatie in grondprijzen werkt daarom niet door in de kansrijkdomkaarten. Voor grootschalige kaarten met een veel lokale details, gaan de details die liggen binnen een watersysteemeenheid verloren.

Van een aantal criteria zijn geen ruimtelijke gegevens voorhanden. Deze kunnen daarom niet worden meegewogen in de kansrijkdom. Sociaaleconomische factoren, zoals samenwerking en beheer(kosten) zijn ook niet altijd ruimtelijk specifiek. In een verdere uitwerking per gebied zouden deze criteria ook meegewogen moeten worden.

\section{Onnauwkeurigheden verminderd met een $10 \%$-criterium}

De begrenzing van de verschillende kaarten bevatten geen gemeenschappelijke geometrische basis en hebben alle een verschillende nauwkeurigheid. Met andere woorden: de locatie van een grens op de kaart kan 5, maar ook 2 of 10 meter verschillen met de werkelijke ligging, als er al scherpe grenzen te trekken zijn. Door een gebrek aan een gezamenlijke geometrische basis kunnen er door deze onnauwkeurigheden na de combinatie van kaarten heel kleine vlakjes ontstaan die als 'ruis' kunnen worden aangeduid. Deze ruis willen we zo min mogelijk laten doorwerken in de kansrijkdom en daarom hebben we voor een oppervlakte-aandeel van minimaal $10 \%$ in de watersysteemeenheid gekozen. Een oppervlakteaandeel kleiner dan dit minimum krijgt dan de waarde 0 , alsof het niet aanwezig is. Deze $10 \%$ is wat arbitrair en zou ook $5 \%$ of $15 \%$ kunnen zijn. We hebben de meest optimale nauwkeurigheidcorrectie voor elke kaart ten opzichte van de watersysteemeenheden niet getoetst. Op basis van expertkennis denken we met $10 \%$ aan de veilige kant te zitten, met name bij de wat grotere watersysteemeenheden. Uit de resultaten blijkt dat dit percentage aan de hoge kant is voor een aantal criteria, waardoor de kansrijkdom minder hoog is dan verwacht. Wanneer er meer informatie beschikbaar is over de onnauwkeurigheden (bijvoorbeeld na een gevoeligheidsanalyse) kan het percentage, eventueel per criterium, worden aangepast.

Voor kaarten met lijnelementen is de bedekking van $10 \%$ al snel te hoog en is een percentage van 0,5-1\% gekozen (zie Tabel 5.2). De kansrijkdom van zeer kleine of zeer smalle (zoals de kanalen in Friesland) oppervlakten moet met voorzichtigheid geïnterpreteerd worden.

\section{Een flexibel eindresultaat door weging van de criteria voor succes}

De criteria kunnen op verschillende manieren worden gewogen en allerlei verschillende waarden meekrijgen. Dit betekent dat de methode in ontelbaar veel mogelijke 'kansrijkdomkaarten' kan resulteren, afhankelijk van welke criteria het belangrijkst worden gevonden. Er is dus niet één eindresultaat. Toch zitten er wel patronen in de kansrijkdomkaarten en is een hoge kansrijkdom in een bepaalde mate gecorreleerd met watersysteemeenheden waar veel criteria voor succes aanwezig zijn. Immers, in de watersysteemeenheden met veel criteria is er bij weging ook een grotere kans dat de gewogen criteria ook in dit gebied meetellen.

\subsection{Robuuste natuur uit Natuurvisie is kansrijk, mits...}

Uit de analyse van de Best Practices blijkt dat robuuste natuur uit de natuurvisie op verschillende onderdelen kansrijk is, maar het ideaalbeeld van robuuste natuur nog in geen van deze gebieden is bereikt. In welke mate deze onderdelen kansrijk zijn, wordt in deze paragraaf beschreven.

\section{Er is aandacht en ruimte voor landschapsvormende processen en natuurlijke processen} Natuurlijke processen komen overal voor en overal zijn er mogelijkheden voor meer ruimte voor deze processen. Zo kunnen er in veel meer gebieden dan nu dikke stammen dood hout en kadavers blijven liggen. Moeilijker wordt het om hydrologische processen te herstellen (kwel, stagnatie, peilfluctuaties e.d.). Grote natuurgebieden met landschappelijke overgangen en reliëf hebben de meeste potentie voor herstel van allerlei hydrologische processen, maar ook in kleine natuurgebieden of in het 
landbouwgebied is er potentie voor meer natuurlijke hydrologische processen (zie de gebiedsgrootte van de watersysteemeenheden). De meest kansrijke gebieden voor natuurlijke processen zijn de gebieden met veel variatie in reliëf, expositie, bodemsamenstelling en waterhuishouding.

Landschapsvormende processen komen vooral in het kustgebied en in het rivierengebied nog steeds in bepaalde mate voor. Hier heeft het stromende water voldoende kracht voor erosie en sedimentatieprocessen. De invloed van deze processen is meestal door menselijke invloed (waterkeringen e.d.) ingeperkt. Maar er is potentie voor meer ruimte voor deze processen. Vooral het rivierengebied, waar de uitgangssituatie enkele decennia geleden veelal uit landbouwgrond bestond, laat zien welke potentie er is bij ontwikkeling van natuurlijke processen. Veel van deze toenmalige landbouwgronden zijn nu leefgebied van zeldzame soorten en zijn daarom zelfs Natura 2000-gebied.

Ook in de duinen zijn veel mogelijkheden voor een dynamischer kustbeheer. Al sinds de eerste Kustnota uit 1990 besteedt men meer aandacht aan natuurlijke dynamiek. De uitgangssituatie is hier meestal echter al Natura 2000-gebied, waardoor er bij ontwikkeling van robuuste natuur ook weer kwetsbare natuurwaarden verloren kunnen gaan.

\section{Lage beheerlasten beperkt haalbaar}

We hebben geen specifieke economische analyse gedaan om aan te tonen of er ook sprake is van lagere beheerlasten. Beheerkosten (normkosten) zijn wel verbonden aan de beheertypen. De beheertypen van de best practices op de beheertypenkaart bestaan uit half-natuurlijke of grootschalige beheertypen; er zijn immers geen beheertypen die specifiek gericht zijn op robuuste natuur. De jaarvergoeding behorende bij de Subsidieverordening natuur- en landschapsbeheer is voor de grootschalige beheertypen minder hoog dan voor de half-natuurlijke typen. De grootschalige natuur moet echter wel aan bepaalde criteria voor natuurlijkheide en biodiversiteit voldoen. Grootschalige beheertypen (zand- en kalklandschap en rivier- en moeraslandschap) staan op kaart in de Gelderse poort, de Veluwezoom en in de Oostvaardersplassen.

De kosten voor het vegetatiebeheer zijn echter niet de enige kosten. Sommige natuurlijke processen hebben een keerzijde, omdat er bijvoorbeeld schade aan gewassen of roerend goed kan ontstaan of vanwege extra risico's voor water- of verkeersveiligheid. Door aanvullende maatregelen, zoals inrichtingsmaatregelen of populatiebeheer, kunnen schade of risico's meestal beperkt, gemitigeerd of gecompenseerd worden. Deze aanvullende maatregelen kosten echter extra geld waardoor de gewenste lage beheerlasten weer deels teniet worden gedaan. Bovendien moeten deze processen vaak toch nog in bepaalde mate gereguleerd worden, waardoor er niet maximaal kan worden aangesloten bij natuurlijke processen. Periodiek (of cyclisch) beheer is dan nodig om successie te kunnen terugzetten. De gewenste en natuurlijke processen in combinatie met lage beheerlasten die de Rijksvisie aan robuuste natuur geeft, kunnen op deze manier niet volledig worden gerealiseerd. De mate waarin de keerzijde van de positieve ontwikkelingen optreedt, is echter afhankelijk van de omstandigheden op een specifieke locatie.

Kwantificering van ecosysteemdiensten in geldtermen kan een bijdrage leveren aan het besef dat natuur en biodiversiteit de maatschappij niet alleen maar geld kosten, maar eerder de 'kip met de gouden eieren' is die baten genereert (Hajer, 2010). Deze bewustwording kan bijdragen aan een meer robuuste financiële basis voor het creëren en beheren van natuurgebieden die een aantal van deze diensten kunnen leveren. Met andere woorden: de baten van de ecosysteemdiensten zouden ingezet kunnen worden om beheer en inrichting te financieren. Helaas zijn echter niet alle baten in financiële termen uit te drukken.

\section{Er is vraag naar ecosysteemdiensten en er zijn maatschappelijke opgaven}

Veel ecosysteemdiensten zijn vervangen door technische of chemische oplossingen. Natuurlijke ziekte en plaagbestrijding door chemische middelen, natuurlijke waterzuivering door waterzuiveringsinstallaties etc. Veel van deze technische oplossingen zijn niet meer weg te denken (bijvoorbeeld waterzuiveringsinstallaties, landbouwmechanisatie, waterbeheersing) en kunnen ook duurzaam worden vormgegeven. Daar waar technologische oplossingen tekortschieten in duurzaamheid (milieudruk, energie, kosten), kan het benutten van ecosysteemdiensten een belangrijke meerwaarde bieden (Melman \& van der Heide, 2010). Bovendien neemt de vraag naar ecosysteemdiensten toe (De Knegt et al,. 2014). Meestal zijn technische oplossingen voorhanden voor 
het verlenen van één enkele dienst, terwijl natuurlijke oplossingen mogelijkheden bieden voor combinaties van diensten. Een combinatie van maatschappelijke opgaven kan de ontwikkeling van robuuste natuur faciliteren. Natuurgebieden kunnen worden benut voor waterzuivering, wateropvang, waterkering, houtoogst, $\mathrm{CO}_{2}$-vastlegging en hebben tegelijkertijd ook een hoge belevingswaarde voor recreanten.

\section{Nationale doelen haalbaar met robuuste natuur}

Een uitgangssituatie met nauwelijks natuurwaarden, zoals kale bodem, landbouwgrond of bomenakkers, kan een spectaculaire biodiversiteitwinst geven, vooral als landschapsvormende of hydrologische processen de ruimte krijgen. Enkele voorbeeldgebieden die nu Natura2000-gebieden zijn, waren nog niet zo lang geleden landbouwgronden en geven een beeld van de mogelijke effecten van natuurontwikkeling op biodiversiteit. Productiebos op de kaarten is gebruikt als selectie voor een uitgangssituatie met weinig natuurwaarden. Dit is niet geheel terecht. Eigenlijk zou je hier alleen de homogene gelijkjarige naaldbossen (bomenakkers) willen selecteren. Sinds 1975 is het monofunctionele bosbeheer namelijk veranderd in een multifunctioneel beheer, waardoor het merendeel van de monocultuurbossen met een houtproductiedoelstelling zich doorgaans al heeft ontwikkeld tot een biodiverser bos. Zo is het areaal ongemengd naaldbos afgenomen van $40 \%$ in 1984 naar 24\% in 2013 (CBS et al., 2014b).

Uit die best practices komt naar voren dat vooral beschermde soorten die zich makkelijk verspreiden, zoals vogels maar ook zoogdieren zoals bevers, snel profiteren van deze nieuwe robuuste natuur. Maar ook het aanleggen van stuifkuilen in de zeereep, het herstel van hydrologische processen - zoals kwel of peildynamiek - mits de waterkwaliteit op orde is, zorgen voor een snelle ontwikkeling van potentieel leefgebied van allerlei zeldzame plantensoorten.

Specifieke biodiversiteitsdoelen moeten bepaald worden op gebiedsniveau, bijvoorbeeld na het uitvoeren van een Landschapsecologische systeemanalyse (LESA; van der Molen et al., 2010). Een LESA beschrijft de karakteristieke abiotische samenhang, natuurlijke processen en de hierdoor gestuurde karakteristieke vegetatieontwikkelingen. De uitkomst van de LESA biedt meerdere mogelijkheden voor de formulering van doelen ten aanzien van behoud, herstel en ontwikkeling, bijv. in hoeverre grondwaterafhankelijke natuur kan worden behouden of hersteld (Bijlsma et al., 2016). Gebaseerd op de uitkomsten van een LESA kan men haalbare doelen voor een gebied formuleren.

\section{Mee bewegen met klimaatverandering kan op verschillende schaalniveaus}

Een robuust natuurnetwerk zorgt daarmee ook voor robuuste natuur. Door gebieden te vergroten en met elkaar te verbinden in een natuurnetwerk ontstaat er meer leefgebied voor soorten en krijgen soorten meer uitwijkmogelijkheden en zijn daardoor minder kwetsbaar voor klimaatverandering. Door klimaatveranderingen zijn er jaren natter, droger, warmer of juist kouder dan normaal. Sommige soorten gedijen bij deze extremen, andere soorten hebben het echter moeilijk. Om te kunnen meebewegen met klimaatverandering is een adaptatiestrategie van belang (zie tekstbox Klimaatadaptatiestrategie).

De klimaatcorridors zoals op kaart gezet door Vonk et al. (2010), behalve die van kust en duin, zijn meegenomen als criterium. Kust en duin valt vooral samen met bestaande natuurgebieden en grote wateren en is daarom niet als klimaatcorridor in de kansrijkdomkaart meegenomen. Heterogeniteit in de vorm van reliëf is beschikbaar als kaart (AHN) en als criterium meegenomen in de kansrijkdomkaarten. Heterogeniteit op landschapsniveau is een criterium als er drie of meer landschapstypen (ecosecties van de landschappelijke bodemkaart) binnen de watersysteemeenheid voorkomen. Ook de potentie voor natuurlijke processen of dynamiek in zoverre beschikbaar op kaart is als criterium meegenomen. Mogelijkheden voor robuuste natuur die kan meebewegen met klimaatverandering is daarmee onderdeel van de criteria voor robuuste natuur. 
Klimaatadaptatiestrategie

De adaptatiestrategie bestaat uit drie pijlers zodat gebieden beter bestand zijn tegen weersextremen:

1. Natuurgebieden met elkaar verbinden om het migreren van soorten mogelijk te maken.

2. De heterogeniteit en gradiënten vergroten in natuurgebieden en omringend landschap.

3. De standplaatscondities in natuurgebieden verbeteren en daarbij zo veel mogelijk gebruikmaken van natuurlijke landschapsvormende processen.

Met andere woorden: het adaptief vermogen van de natuur in Nederland neemt toe door verbetering van de ruimtelijke samenhang, heterogeniteit, dynamiek en milieu- en watercondities van natuurgebieden.

Ad 1. Ecologische netwerken van ecosystemen zijn van cruciaal belang. Als gebieden te klein zijn en een soort verdwijnt door extreme weersomstandigheden, dan is herstel alleen mogelijk vanuit natuurgebieden in de omgeving. Ook schuiven geschikte leefgebieden door klimaatverandering op naar het noorden. Soorten moeten dan wel in staat zijn het oude gebied te herkoloniseren of nieuwe leefgebieden te koloniseren, zodat zij de klimaatverandering beter bij kunnen houden. Daarvoor moeten de kleine en/of nieuwe gebieden wel in een ecologisch netwerk liggen. Voor klimaatveranderingen zijn zoekgebieden gedefinieerd waar dit netwerk het best gerealiseerd kan worden: de klimaatcorridor moeras, het heidecluster, zijtakken Europese klimaatcorridor bos en de klimaatcorridor duin en kust.

Ad 2. Variatie in standplaatscondities (heterogeniteit) is ook een belangrijke component van het adaptief vermogen van een ecosysteem. Reliëf zorgt voor grondwaterstromen en gradiënten in milieucondities, zoals overgangen van nat naar droog, voedselrijk naar voedselarm, basenrijk naar zuur en van zoet naar zout. Heterogeniteit in reliëf en milieucondities dempt het effect van weersextremen (soorten hebben uitwijkmogelijkheden) en verlaagt hiermee het risico op regionaal uitsterven onder extreme weersomstandigheden (risicospreiding). Bijvoorbeeld in een extreem droog jaar waarbij locaties verdrogen, zijn in een heterogeen gebied altijd wel uitwijkmogelijkheden naar locaties die niet uitgedroogd zijn. Herstel treedt op vanuit die delen van het gebied die niet zijn getroffen en van waaruit het getroffen deel opnieuw kan worden gekoloniseerd. Heterogeniteit is belangrijk op lokaal niveau (binnen natuurgebieden), maar ook op regionaal niveau (binnen landschappen). Bovendien biedt een hoge mate van heterogeniteit ruimte aan meer soorten, omdat elke soort een eigen optimum in het landschap kan vinden. Een hoge biodiversiteit draagt weer bij aan risicospreiding als relaties in de voedselketen wegvallen.

Ad 3. Achteruitgang van biodiversiteit in Nederland wordt ook veroorzaakt door verdroging, vermesting en verzuring. Klimaatverandering kan deze milieu-drukfactoren mogelijk versterken. Afhankelijk van de omvang en de richting van de klimaatverandering zal dit zowel positieve als negatieve effecten hebben op de standplaatscondities. De grotere schommelingen in de waterhuishouding en de uitdroging in de zomer vragen bijvoorbeeld om extra maatregelen in de waterhuishouding.

Bron: Vonk et al., 2010.

\subsection{Kansrijke gebieden voor robuuste natuur}

De methode laat zien dat er kansen zijn voor robuuste klimaatbestendige natuur wanneer er vraag is naar ecosysteemdiensten en er potentie is voor natuurlijke processen, zoals langs de grote rivieren, in beekdalsystemen, Drentsche Aa en midden Drenthe, de Lunterse beek en in de Gelderse vallei en enkele watersysteemeenheden van de Friese boezem. In meer of mindere mate zijn het veelal dezelfde gebieden die kansrijk zijn.

Robuuste natuur met een landbouwfunctie en in grote wateren blijft onderbelicht. De mogelijkheden voor robuuste natuur langs de kust komen niet goed uit de verf, omdat de gebruikte kaarten nauwelijks kustdynamiek-gegevens bevatten. De grote wateren zijn daarom niet meegenomen in de berekeningen, wat zijn weerslag heeft op de kansrijkdom van de kust en de duinen. Hier zou in een vervolgonderzoek meer aandacht aan besteed kunnen worden. Bovendien leveren de kustduinen veel ecosysteemdiensten die niet doorwerken in de kansrijkdom, omdat het aanbod ervan groter is dan de 
vraag (De Knegt et al., in prep). Voor ontwikkeling van robuuste natuur is een deel van de gebieden daarom volgens de gebruikte methodiek minder kansrijk.

Kansen voor herstel van ecosysteemdiensten middels de aanleg van robuuste natuur liggen ook in het agrarisch gebied. Dat hoeft niet per definitie een transformatie te zijn van agrarisch gebied naar natuurgebied. Robuuste natuur kan ook de gedaante hebben van robuuste, duurzaam beheerde landbouwgebieden, waar ecosysteemdiensten zijn hersteld en waar de sterk bedreigde agrarische biodiversiteit weer kansen krijgt. Dit sluit ook in belangrijke mate aan bij de Uitvoeringsagenda Natuurlijk Kapitaal, waarmee het kabinet streeft naar een duurzaam landbouwkundig beheer in 2020, zodat biodiversiteit behouden blijft (EZ \& I\&M, 2013) en sluit aan bij de doelstellingen voor een duurzaam gebruik van biodiversiteit (CBD). Ook consumenten besteden steeds meer geld aan duurzaam voedsel (Logatcheva, 2014). Producenten volgen de consumenten, maar ook bij de boeren zelf blijkt er in toenemende mate interesse voor duurzaamheidsaspecten zoals een goede bodemstructuur, ontwatering, organische stof en bodemleven (Rougoor et al., 2013).

Door de keuze van de best practices is er weinig aandacht voor meer natuurlijkheid in het agrarisch gebied. De mogelijkheden voor een meer natuurinclusieve landbouw zijn echter legio (Sanders \& Westerink, 2015). Het gaat daarbij bijvoorbeeld om:

- Ecosysteemdiensten zoals biologische plaagbestrijding, bestuiving, natuurlijke bodemvruchtbaarheid, kruidenrijke hooilanden etc.

- Aanleg natuurvriendelijke oevers in poldersloten.

- Natuurlijker waterbeheer, minder diepe drainage.

- Spontane successie op braakliggende terreinen en randen (soortenrijke akkerranden, natuurbraak, tijdelijke natuur).

Meer natuurlijkheid en robuuste natuur kan overal worden gerealiseerd ongeacht ambitie en schaal, niet alleen in agrarische gebieden, maar ook in de stad. In deze gebieden kan meer ruimte voor natuurlijke processen een belangrijke bijdrage leveren aan het verbeteren van de ecosysteemdiensten en aan de lokale biodiversiteit. Ambitie en schaal bepalen wel de mate waarin robuuste natuur bijdraagt aan de landelijke en internationale natuurdoelen.

\subsection{Gebruiksmogelijkheden kansrijkdomkaarten}

De kansrijkdomkaarten op basis van beschikbaar kaartmateriaal van genoemde criteria resulteren in een eerste verkenning van mogelijke gebieden voor robuuste natuur. De bruikbaarheid van die kaarten moet daarom beoordeeld worden op basis van expert judgement. De kaarten zijn bedoeld om de discussie over de mogelijkheden van robuuste natuur zowel in de provincie als tussen rijk en provincie te faciliteren betreffende criteria die van belang zijn, specifiek prioriteit krijgen en in welke gebieden de meeste mogelijkheden zijn.

Voor het maken van concrete plannen voor de ontwikkeling van robuuste natuur moet er een nadere analyse worden uitgevoerd. Criteria waarvoor geen kaartmateriaal beschikbaar is of waarvoor de ruimtelijke dekking ontoereikend is, zijn immers niet meegenomen in het berekenen van de kansrijkdom. Bij een verdere uitwerking op gebiedsniveau kunnen die factoren van doorslaggevend belang zijn. Lokaal of regionaal kunnen er bovendien belangen meespelen die niet op nationaalniveau in kaart gebracht kunnen worden. Ook zijn er allerlei lokale fysische kenmerken die het succes van robuuste natuur kunnen beïnvloeden. Een landschapsecologische analyse (LESA) kan de gebiedspecifieke inzichten geven (zie Bijlsma et al., 2016) wat betreft de aard, omvang en haalbaarheid van de gewenste natuurlijke processen. Na de LESA kunnen de gewenste natuurdoelen voor het gebied concreet worden uitgewerkt en zal ook het betrekken van de verschillende (gebieds)partijen en het optimaliseren van de mogelijkheden voor het leveren van ecosysteemdiensten een belangrijke opgave zijn voor het maken van concrete plannen. Formulering van gebiedsdoelen is uiteindelijk een beleidskeuze. 


\section{Literatuur}

Bal, D., H.M. Beije, M. Fellinger, R. Havenman, A.J.F.M. van Opstal \& F.J. van Zadelhoff, 2001. Handboek Natuurdoeltypen. Ministerie van LNV, Den Haag.

Bijlsma, R.J., A.J.M. Jansen, J.A.M. Janssen, G.J. Maas \& P.C. Schipper, 2016. Kansen voor voor meer natuurlijkheid in Natura 2000-gebieden. Alterra-rapport, Alterra Wageningen UR.

Boekel, E.M.P.M. van, P. Bogaart, L.P.A. van Gerven, T. van Hattum, R.A.L. Kselik, H.T.L. Massop, H.M. Mulder, P.E.V. van Walsum en F.J.E. van der Bolt, 2012. Evaluatie Landbouw en KRW. Evaluatie Meststoffenwet 2012: deelrapport ex post. Alterra-rapport 2326, Alterra Wageningen UR.

CBS, PBL, Wageningen UR, 2014. Veiligheid primaire waterkeringen, 2001 - 2013 (indicator 2043, versie 04, 10 september 2014). www.compendiumvoordeleefomgeving.nl. CBS, Den Haag; Planbureau voor de Leefomgeving, Den Haag/Bilthoven en Wageningen UR, Wageningen.

CBS, PBL, Wageningen UR, 2014b. Areaal bostypen 1984 - 2013 (indicator 1160, versie 07 , 23 juli 2014 ). www.compendiumvoordeleefomgeving.nl. CBS, Den Haag; Planbureau voor de Leefomgeving, Den Haag/Bilthoven en Wageningen UR, Wageningen.

CBS, PBL, Wageningen UR, 2015. Bever, 1988-2013 (indicator 1061, versie 09, 15 april 2015). www.compendiumvoordeleefomgeving.nl. CBS, Den Haag; Planbureau voor de Leefomgeving, Den Haag/ Bilthoven en Wageningen UR, Wageningen.

Cox. M., R. Schippers, A. van Vugt \& L. Fleskens, 2014. Beverprotocol Brabant. Waterschap Aa en Maas, Brabantse Delta en Dommel. 22p.

Delft, S.P.J. van, G.J. Maas \& A.H. Heidema, 2015. Atlas Landschappelijke Bodemkaart. Alterra Wageningen UR http://www.landschapsleutel.wur.nl/documentatie/Atlas\%20LBK.pdf

DR, 2014. Actualisatie omgevingsvisie Drenthe, Provincie Drenthe.

EC, 2013. Guidelines on wilderness in Natura 2000. Management of terrestrial wilderness and wild areas within the Natura 2000 Network. Technical Report 2013-069. European Commission. http://ec.europa.eu/environment/nature/natura2000/wilderness/pdf/WildernessGuidelines.pdf

Kramer, K. \& I. Geijzendorffer (red.), 2009. Ecologische veerkracht: Concept voor natuurbeheer en natuurbeleid. KNNV Uitgeverij, Utrecht.

Groot-Bruinderink, G.W.T.A. D.R. Lammertsma, P.W. Goedhart, W.G. Buist, R.M.A. Wegman \& G.J. Spek, 2009. Factoren bij aanrijdingen met wilde hoefdieren op de Veluwe. Alterra rapport 2026. 42 pag.

Goossen, C.M, M. Sijtsma, H. Meeuwsen \& J. Franke, 2011. Vijf jaar daarmoetikzijn; Het ideale landschap volgens de Nederlanders op basis van analyse van de website www.daarmoetikzijn.nl. Alterra-rapport 2197. Alterra Wageningen UR.

Hazeu, G.W., C. Schuiling, G.J. Dorland, G.J. Roerink, H.S.D. Naeff \& R.A. Smidt, 2014. Landelijk Grondgebruiksbestand Nederland versie 7 (LGN7); Vervaardiging, nauwkeurigheid en gebruik. Alterra-rapport 2548. Alterra Wageningen UR.

Inspectie Leefomgeving en Transport, 2013. Resultaten verlengde derde toets primaire waterkeringen. Ministerie van Infrastructuur en Milieu, Den Haag.

Klijn, J.A., 2011. Wisselend getij. Omgang met en beleid voor natuur en landschap in verleden en heden; een essayistische beschouwing. Achtergronddocument bij Natuurverkenning 2011. WOtwerkdocument 239. Wettelijke Onderzoekstaken Natuur \& Milieu, Wageningen.

Knegt B. de, et al., 2014. Graadmeter Diensten van Natuur; Vraag, aanbod, gebruik en trend van goederen en diensten uit ecosystemen in Nederland. WOt-technical report 13. Wettelijke Onderzoekstaken Natuur \& Milieu, Wageningen.

Knegt, B. de, D.C.J. van der Hoek, C. Veerkamp, I. Woltjer, M. van der Aa, E. van Boekel, J. Diederiks, H. Goosen, C.A.M. Hendriks, A. Koekoek, J.P. Lesschen, I. Staritsky, F. Veenenklaas, F. de Vries, in prep. Kansenkaarten voor duurzaam benutten van Natuurlijk Kapitaal. WOT technical report. Wettelijke Onderzoekstaken Natuur \& Milieu, Wageningen.

Kuiper, M.J. \& H.J. Krajenbrink, 2013. Onderzoek grondwateroverlast regio Zuid-Kennemerland. Rapport KN23 RAP20131126. Wareco Ingenieurs. 
Kwak, A. \& L. Kuiters, 2014. Wildernis in een getemd Europa. In J. Schaminée \& J. Janssen (red.), Het oude continent. Beschouwingen over natuur in Europa. KNNV Uitgeverij, Zeist.

Logatcheva, K., 2014. Monitor Duurzaam Voedsel 2014. Consumentenbestedingen. LEI Factsheet 2014. 13p.

EL\&I, 2013. Kamerbrief, kenmerk DGNR-NB / 13157005 Ministerie van Economische Zaken, Landbouw en Innovatie. Bijlage Natuurpact.

EZ \& I\&M, 2013. Uitvoeringsagenda Natuurlijk Kapitaal. Ministerie van Economische zaken, Den Haag.

EZ, 2014a. Natuurlijk verder; Rijksnatuurvisie 2014. Ministerie van Economische zaken, Den Haag.

EZ, 2014b. Natuurambitie Grote Wateren 2050 en verder. Ministerie van Economische zaken, Den Haag.

Hajer, M., 2010. Een bewogen Beweging; Lezing op het Voorjaarsforum van Natuurmonumenten. 21 april 2010.

Hattum, T. van; C. Kwakernaak, T.P. van Tol-Leenders, J. Roelsma, M.E.A Broekmeyer, A.M. Schmidt, E.M. Hartgers, \& S.L. Nysingh, 2014. Water en natuur: een mooi koppel! : onderzoek naar de succesfactoren, belemmeringen en kansen voor het meekoppelen van water- en natuuropgaven. Alterra-rapport 2533. Alterra, Wageningen UR.

MEA, 2005. Millenium Ecosystem Assessment. Ecosystems and Human Well-being; Synthesis. Washington DC, Island Press.

Melman, T C P, \& C.M. van der Heide, 2010. Ecosysteemdiensten in Nederland: verkenning betekenis en perspectieven : achtergrondrapport bij Natuurverkenning 2011. Wettelijke Onderzoekstaken Natuur \& Milieu, Wageningen.

Mens, M.J.P., J.H. Kwakkel, A. de Jong, W.A.H. Thissen \& J.P. van der Sluijs, 2012. Begrippen rondom onzekerheid. Kennis voor Klimaatrapport 049/2012. Deltares/TU Delft/Universiteit Utrecht.

Molen, P.C. van der, G.J. Baaijens, A. Grootjans \& A. Jansen, 2010. LESA. Landschapsecologische systeemanalyse. www.natura2000.nl/pages/landschapsecologische-systeemanalyse-lesa.aspx

Mumby, P.J., I. Chollett, Y. Bozec \& N.H. Wolff, 2014. Ecological resilience, robustness and vulnerability: how do these concepts benefit ecosystem management.

$\mathrm{NH}, 2015$. Meer ruimte voor natuurlijke processen in Noord-Holland? Een verkenning naar de betekenis van meer ruimte voor natuurlijke processen. Provincie Noord-Holland.

NM, 2012. Visie Natuurmonumenten op natuur en landschap in 2040. Natuurmonumenten, 's Graveland.

PBL, 2007. Nederland Later. Tweede Duurzaamheidsverkenning, deel Fysieke leefomgeving Nederland. MNP-publicatienummer 500127001/2007. Milieu- en Natuurplanbureau, Bilthoven.

Puijenbroek, P.J.T.M. van, \& J. Clement, 2010. Basiskaart Aquatisch: de Watertypenkaart. PBLpublicatienummer 500067004. Planbureau voor de Leefomgeving, Den Haag, Bilthoven.

Roos, R., F. Saris \& N. van der Wel (red.), 2014. Woorden over de wildernis. Oude en nieuwe visies op de natuur. Natuurmedia, Amsterdam.

Rougoor, C., E. van Well \& E. de Lijster, 2013. Bewegingen en trends binnen de landbouw ten aanzien van energie en klimaat. CLM Onderzoek en Advies BV: 51 p.

Sanders M.E. \& J. Westerink, 2015. Naar een natuurinclusieve duurzame landbouw. Brochure Alterra Wageningen UR.

SBB, 2015. Ziel en zakelijkheid. Ondernemingsplan Staatsbosbeheer 2020.

Schipper, P. \& H. Siebel (red.) 2013. Index Natuur en landschap. Onderdeel natuurbeheertypen. Versie 0.5 Januari 2013. http://www.portaalnatuurenlandschap.nl/assets/Index-Natuur-2014stroomlijning-en-wijzigingen-tov-versie-2012-website.pdf

Sterk, M., 2015. Operationalising resilience for ecosystem management by assessing ecosystems' adaptive capacity. PhD thesis Wageningen UR.

Vonk, M., C.C. Vos en D.C.J. van de Hoek, 2010. Adaptatiestrategie voor een klimaatbestendige natuur. Planbureau voor de Leefomgeving (PBL), Den Haag/Bilthoven.

VROM, 2006. Nota Ruimte, ruimte voor ontwikkeling. Deel 4: Tekst na parlementaire instemming. Ministerie van Volkshuisvesting, Ruimtelijke Ordening en Milieubeheer, Den Haag.

Wilderness act, 1964. Public Law 88-577 (16 U.S. C. 1131-1136), 88th Congress, Second Session September 3, 1964.

Wolf, J.A., 2012. Wildernis in Nederland tussen droom en werkelijkheid. Een onderzoek naar de fysieke wildernis en de beeldvorming over wildernis in Nederland in verleden en heden. Masterscriptie Rijksuniversiteit Groningen. 


\section{Bijlage 1 Beschrijving best practices}

\section{Veluwezoom}

Nationaal park De Veluwezoom is een ruim 5000 ha groot gebied en onderdeel van het Natura 2000gebied 'Veluwe'. Dit stuwwallenlandschap is verbonden met het rivierenlandschap via 'ecologische poorten' als Soerense Poort en Havikerpoort. Het gebied bestaat uit vele gradiëntrijke overgangen van hoog naar laag (reliëf), van arm naar rijk (bodem) en van droog naar nat (vochthuishouding).

Natuurlijk processen en menselijke invloed hebben het gebied gevormd. Landschapsvormend waren de geomorfologische processen door schuivend en smeltend landijs in de ijstijd en erosie en sedimentatie door de rivieren en wind in de tijd daarna. Op een kleinere schaal leidden processen zoals kwel, overstroming en sedimentafzetting, verstuiving, hellingerosie maar ook graafwerkzaamheden en het opwerpen van grond tot tal van verschillen in o.a. bodemsamenstelling, reliëf, expositie en waterhuishouding. Ook agrarische activiteiten, bosbouw en jacht hadden een groot effect op de biotische en abiotische variatie. Door al deze - in tijd en ruimte verschillende - processen en activiteiten is een gevarieerd landschap ontstaan. De menselijke invloed leidde echter ook tot beperking van diverse natuurlijke processen en ontwikkelingen, zoals verminderde natuurlijke successie, minder afbraak van divers organisch materiaal, stabiele populatiesamenstelling en -omvang van grote herbivoren en predatoren en daarmee van de begrazingsdruk en het wroeten van wilde zwijnen. Het landschap "verstilde".

Natuurmonumenten wilde zo'n dertig jaar geleden een meer natuurlijk bos en zo'n twintig jaar geleden kregen natuurlijke processen voorrang boven een beheer gericht op het in stand houden van (landschaps)patronen. Hoewel de grote landschapsvormende processen door ijs, water en wind tot het verleden behoren, kan het achterwege laten van menselijk ingrijpen (bosbouw, jacht, landbouw / beheeractiviteiten zoals plaggen) de abiotische heterogeniteit verder vergroten waardoor nieuwe gradiënten en een ruimtelijk meer heterogeen vegetatiepatroon ontstaan. Al dertig jaar vindt op ca. $2 / 3$ van het gebied daarom een terughoudende vorm van beheer plaats waarbij de natuur mag bepalen wat de richting is. Natuurlijke ontwikkelingen en processen krijgen daar waar mogelijk, zinvol en niet in strijd met overige waarden voorrang en ruimte. Natuurmonumenten streeft echter niet om herstel of terugkeer naar een 'oer'-situatie, dat is volgens hen verleden tijd. Het gaat hen ook niet om een 'nagenoeg natuurlijk landschap', maar om een natuurlijker landschap. De nadruk ligt daarbij op soorten die het uiterlijk van het landschap mede bepalen, bijvoorbeeld de diverse dominante boomsoorten en grotere zoogdiersoorten. Deze mogen zich zo veel mogelijk op eigen kracht vestigen, verspreiden, sterven door ouderdom, ziekte, predatie e.d. en niet door oogst. Kadavers en dood hout blijven als biomassa liggen.

In 2014 heeft Natuurmonumenten een Toekomstvisie voor de Veluwezoom uitgebracht, waarin ook de ontwikkelingen van afgelopen decennia staan beschreven. Het weer toestaan van deze natuurlijke processen en ontwikkelingen hebben de afgelopen decennia al bijgedragen aan een verdere heterogeniteit en diversiteit. Zo komen op enkele locaties met permanente aanwezigheid van dikker dood hout bijzondere insectensoorten voor. Op veel plaatsen zijn de bossen gevarieerder geworden in samenstelling en structuur. Door begrazing heeft de vegetatiestructuur van bos, heide en voormalige bouwlanden meer mozaïekpatronen qua soortensamenstelling en gelaagdheid en ontstaan er open plekken en looppaadjes. Onder invloed van begrazing gaat de heide, vergrast met bochtige smele of pijpenstrootje, over in mozaïeken van andersoortige heidebegroeiing, o.a. met bosbesheide. Door decennialange ontwikkeling van een humuslaag in de heide verschijnen soorten van de natte heide, zoals veenbies in de droge heide.

De ontwikkelingen in het stuwwallengebied zijn vrij traag en daarom gebaat bij continuïteit in beheer. Toch is een meer natuurlijk landschap voor Natuurmonumenten niet hetzelfde als dogmatisch 'niets doen'. Zo heeft zij, vanwege de belevingswaarde van de heide, de aanwezige natuurwaarden en in het 
bijzonder de resultaten van nieuwe ontwikkelingen in de heide (humusprofielvorming en bosbesheide) besloten de heide niet te laten dichtgroeien met grove den, maar met actief ingrijpen open te houden. Daarnaast is het dood hout dat blijft liggen vaak onvoldoende dik, waardoor Natuurmonumenten de permanente aanwezigheid van dik dood hout, zowel staand als liggend, wil versterken. Ook het beheer van de grote zoogdieren kan beter aansluiten bij 'natuurlijke processen', ondanks het ontbreken van predatoren. Aantalregulatie vindt meestal vanwege praktische omstandigheden niet plaats op momenten dat van nature sterfte zou optreden. Natuurlijke selectiemechanismen worden hierdoor tenietgedaan en ook het natuurlijk gedrag van deze dieren verandert (ze houden zich overdag schuil en mijden de mens). Niet de aantallen dieren zouden richtinggevend moeten zijn voor de mate van afschot, maar de overlast voor verkeer, land- en bosbouw. Vooralsnog wordt aan deze gedachte van natuurlijke populatieontwikkeling invulling gegeven door de instelling van een jachtvrije zone.

Samenvattend zijn de succesfactoren, voorwaarden en keerzijden:

\section{Succesfactoren:}

- Reliëf en gradiëntsituaties zijn ecologisch gezien zeer waardevol. Het zorgt voor grote variatie in abiotiek en soorten kunnen met gradiënten mee opschuiven wanneer de abiotiek verandert door natuurlijke processen. Door dit opschuiven komt lokaal uitsterven minder vaak voor dan bij het ontbreken van gradiënten (ref).

- Ook in verstilde' landschappen zonder grootschalig landschapsvormende processen heeft een natuurlijker beheer een meerwaarde. Op veel plaatsen zijn de bossen en heiden gevarieerder geworden in samenstelling en structuur.

- Groot gebied waardoor kuddes grote zoogdieren zorgen voor grote verschillen in begrazingsdruk.

- Langjarige continuïteit in beheerstrategie zorgt voor onverwachte ontwikkelingen in de heide die van wetenschappelijk belang zijn.

- Variatie en het zien van wild wordt gewaardeerd door recreanten. Zichtbaarheid wild is een aandachtspunt (schuw door afschot).

- De Veluwse poorten bieden kansen om kwaliteiten van de overgangen van het stuwwallenlandschap naar het rivieren landschap te herstellen (rondtrekkende dieren, kwel).

\section{Voorwaarden en keerzijde}

- Geen dogmatisch nietsdoen-beheer, maar zonering in beheerstrategieën en selectief ingrijpen indien nodig om bestaande en nieuwe waarden te behouden en te vergroten.

- In de Toekomstvisie van de Veluwezoom wordt de relatie tussen het stuwwallenlandschap en het rivierenlandschap genoemd, maar niet echt uitgewerkt.

- Door allerlei wettelijke, maatschappelijke en praktische redenen kunnen opbouw en populatieomvang van edelherten, damherten en wilde zwijnen nog niet door natuurlijke selectiemechanismen worden gereguleerd.

\section{Gebruikte bronnen}

- Natuurmonumenten. Toekomstvisie Veluwezoom (Nationaal Park Veluwezoom en IJsseluiterwaarden) 2014 


\section{Hunzedal / Zuidlaardermeerpolders}

De Hunze ontspringt op het Drents plateau en stroomt in noordwestelijke richting, onderlangs de Hondsrug en door de stad Groningen, om vervolgens via het Lauwersmeer uit te monden in de Waddenzee (zie Figuur b1). Afgelopen jaren is er 3000 ha aan nieuwe natuur gerealiseerd en is een rechtgetrokken sloot getransformeerd tot een meanderende beek.

Het Hunzedal is een vlak en breed beekdal. Met de intensivering van de landbouw halverwege de vorige eeuw werd de Hunze gekanaliseerd en werden sloten aangelegd om het kwelwater onder aan de Hondsrug af te voeren. Ook werden verspreid over het Hunzedal grondwaterwinningen ingericht. Hierdoor nam de kweldruk in verschillende delen van het gebied af, met name rond het Zuidlaardermeer. Deze ingrepen hebben een enorme afname van de natuurwaarden in het beekdal tot gevolg gehad.

Begin jaren negentig kwam hierin een ommekeer. Op initiatief van Stichting Het Drentse Landschap werden de mogelijkheden voor natuurontwikkeling in het Drentse deel van het Hunzedal onderzocht. Op basis van historische data, een analyse van het watersysteem en de aanwezigheid van (nog steeds) karakteristieke plantensoorten werd vermoed dat de ecologische potentie van het beekdal nog steeds hoog was. In tegenstelling tot Drenthe was er in het Groningse deel van het beekdal wel nog een flink areaal natuurgebied aanwezig. Maar hier stonden de natuurwaarden sterk onder druk, als gevolg van grondwaterwinning en een verslechterende waterkwaliteit.

In 1995 vonden Het Drentse Landschap en Het Groninger Landschap elkaar in een ambitieus plan: de Hunzevisie. De visie legde de lat hoog: het Hunzedal moest weer een zo natuurlijk mogelijk beekdal worden. Daarbij gold het natuurlijke beekdalsysteem van de Biebzra in Polen als referentiebeeld. Gaandeweg ontstond steeds meer enthousiasme om met de Hunze-visie aan de slag te gaan. Niet in de laatste plaats vanwege publiciteit rond de Hunzevisie door het Wereld Natuur Fonds.

De visie vormde een krachtig instrument voor het zoeken naar functiecombinaties, ofwel het herstel van ecosysteemdiensten, zoals de meekoppeling van natuurontwikkeling met waterberging, waterzuivering en waterwinning. De waterbergende functie van de Zuidlaardermeerpolders bleek bijvoorbeeld van doorslaggevend belang om de stad Groningen droog te houden tijdens de wateroverlast van 1998 en 2012.

De Hunze-akkers zijn een strategisch waterwingebied. Tussen WMD en het Drentslandschap bestonden andere ideeën over de gewenste ontwikkelrichtingen. WMD wilde de natuur reguleren, terwijl het Drents Landschap meer op had met wilde natuur. De landbouwbedrijven worden door WMD jaarlijks gecompenseerd voor nat en droogteschade.

Door het toenmalige ministerie van LNV werd het Hunzedal aangewezen als onderdeel van de Natte As door Nederland. Dit was voor de provincie Drenthe aanleiding om te komen tot een ruimere begrenzing van natuurgronden in het provinciale gebiedsplan voor het Hunzedal. Onder regie van de provincie werd vervolgens het Hunze-project opgezet, waardoor ook de bewoners nauw bij de integrale planvorming werden betrokken. Vanaf 2000 is in Drenthe daardoor sprake van een samenwerking tussen overheden, belangenorganisaties en bewoners bij de uitwerking en realisering van plannen gericht op de plattelandsontwikkeling, inclusief natuurontwikkeling. Aan Groningse zijde vond via de Herinrichting Haren een vergelijkbare ontwikkeling plaats. De plannen werden daarmee ook verbonden met de leefbaarheid van het gebied, waardoor draagvlak ontstond.

Sinds de publicatie van de Hunze-visie in 1995 (Bilt en Glastra, 1995) zijn er vele projecten uitgevoerd en is er opvallend veel succes geboekt. In het Hunzedal is inmiddels ruim 3000 ha nieuwe en vooral natte natuur ontwikkeld. Dat is ruim $40 \%$ van de oppervlakte die in de Hunzevisie werd genoemd. Alle planten- en diersoorten die als doelsoort in de visie werden benoemd, komen inmiddels in het Hunzedal voor. Bijzonder zijn bijvoorbeeld de enige Nederlandse broedkolonies van de Witwangstern en Witvleugelstern, waarvan de dichtstbijzijnde kolonies op honderden kilometers van de grens liggen. De spectaculaire ontwikkelingen zijn het gevolg van het realiseren van een groot, (relatief) aaneengesloten natuurgebied, gevolgd door aanpassingen in de waterhuishouding, waardoor het waterbeheer optimaal worden afgestemd op de natuur. 
Samenvattend heeft het Hunzedal zich vanaf 1995 ontwikkeld tot een aantrekkelijk natuurgebied met een grote maatschappelijke betekenis, vanwege het herstel van vele ecosysteemdiensten, waar eigenlijk alle belanghebbenden bij zijn gebaat. Er liggen nog vele kansen om deze ontwikkelingen met kracht door te zetten (Eijk, 2014).

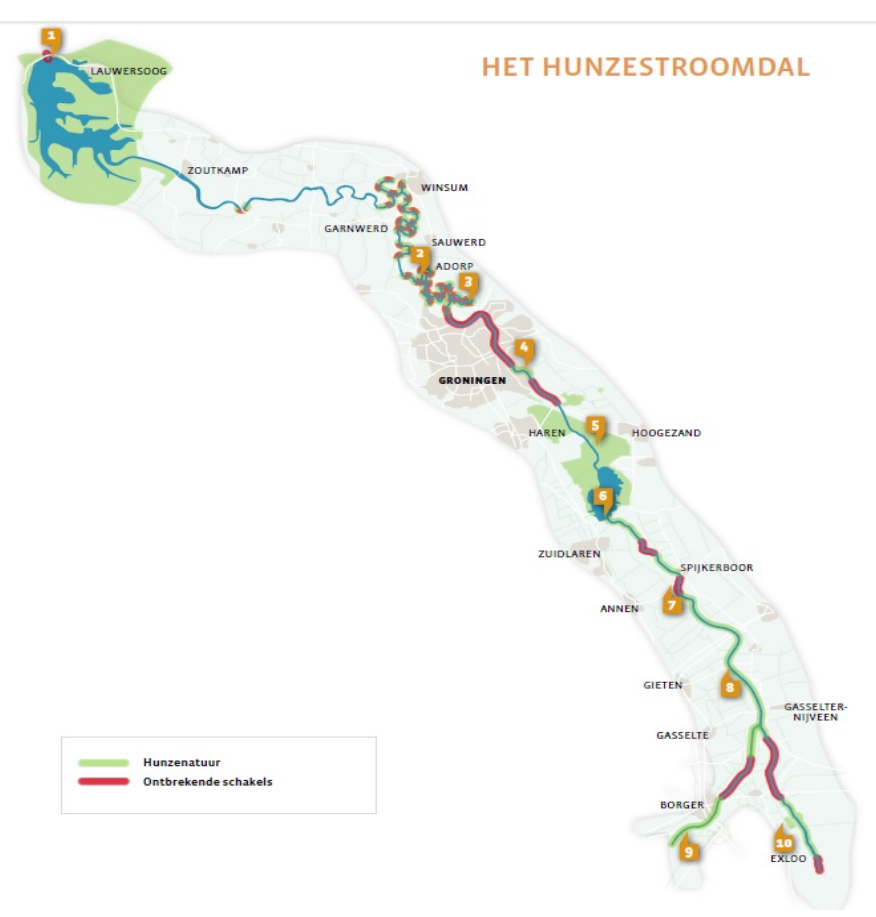

Figuur b1 Het Hunzestroomdal met Hunzenatuur (groen), zoals de ruime Zuidlaardermeerpolders tussen de stad Groningen en het Zuidlaardermeer, en ontbrekende schakels (rood).

\section{Succesfactoren:}

- Hunzevisie als krachtig communicatie-instrument: De Hunzevisie vormde een krachtig communicatief instrument voor het zoeken naar functiecombinaties van natuurontwikkeling met bijvoorbeeld waterberging, -zuivering en -winning. Het WWF had vervolgens een belangrijke rol in de communicatie over de Hunzevisie en het enthousiasmeren van de verschillende belanghebbenden.

- Samenwerking/integrale planvorming: Samenwerking tussen overheden, waterschappen, natuurbeschermingsorganisaties, ondernemers, bewoners en vrijwilligers blijkt voor het Hunzedal de motor te zijn achter de nieuwe natuurontwikkeling.

- Realisatie van functiecombinaties en/of ecosysteemdiensten: De natuurontwikkeling heeft een groot positief effect gehad op andere belangen. De omstandigheden voor waterwinning verbeterden, zowel kwantitatief als kwalitatief. Het Hunzedal is dé leverancier van drinkwater voor Groningen en Drenthe. Het gebied heeft een belangrijke betekenis als waterbergingsgebied gekregen.

- De nieuwe natuur zorgt in deze krimpregio voor een aantrekkelijkere leef- en werkomgeving en lokale ondernemers profiteren van de nieuwe vormen van recreatie die het Hunzedal biedt.

- Grondwerving relatief eenvoudig: Een van de succesfactoren is het feit dat grondverwerving en grondruil goed mogelijk bleken. Boeren konden vaak natte lage gronden ruilen voor beter bewerkbare, hoger gelegen gronden. Hierdoor kon de verkaveling van bedrijven en de bedrijfsstructuur van boeren vaak aanmerkelijk worden verbeterd.

- Groot aaneengesloten gebied: De spectaculaire ontwikkelingen zijn het gevolg van het realiseren van een groot, aaneengesloten natuurgebied, gevolgd door aanpassingen in de waterhuishouding waardoor het waterbeheer optimaal kan worden afgestemd op de natuur. Zo werken de in het vroege voorjaar overstromende zomerpolders, die in de loop van de zomer langzaam droogvallen, als een magneet op bijzondere broedvogels. 
- Kwel basis voor succes natuurontwikkeling: De kansen voor natte en procesgerichte natuurontwikkeling in het Hunzedal zijn buitengewoon groot, met name door het optreden van kwel vanuit de Hondsrug, die langs het hele Hunzedal loopt.

- Nationaal beleid versus provinciaal beleid: De aanwijzing van de Hunze als onderdeel van de Natte As door het toenmalige ministerie van LNV, was van groot belang voor het realiseren van een ruimere begrenzing van natuurgronden in het provinciale gebiedsplan voor het Hunzedal in Drenthe.

- Verankering in natuurbeleid: De natuurwaarden zijn stevig verankerd binnen het provinciaal, nationaal en Europees beleid. De Hunze is onderdeel van de Natte As van het Natuurnetwerk Nederland en grote delen zijn aangewezen als Natura 2000-gebied. De opwaardering van de Hunze pas naadloos in de Europese Kaderrichtlijn water, de Provinciale omgevingsplannen van Groningen en Drenthe, het Waterbeleid $21^{\mathrm{e}}$ eeuw, de Nota Ruimte en de gemeentelijke ruimtelijke- en waterplannen.

\section{Voorwaarden en keerzijde:}

- Voorwaarde voor grootschalige natuurlijke processen nog niet gerealiseerd: Veel is reeds bereikt, maar de Hunze is nog altijd gefragmenteerd. Het vormt nog niet de gewenste levende beek met grootschalige kenmerkende natuurlijke processen als sedimentatie en erosie, stroming en periodieke overstroming. Voor het creëren van een natuurgebied van bron tot Waddenzee inclusief de natuurlijke processen die daarbij horen, dient nog een groot aantal ontbrekende schakels te worden verworven en ingericht (zie figuur).

- Kansen voor creëren van draagvlak voor natuurontwikkeling nog onderbenut: Voor het grote publiek is het Hunzegebied nog steeds onbekend terrein, nationaal maar ook regionaal. De kansen voor de lokale economie en daarmee voor het creëren van draagvlak voor nieuwe natuurontwikkeling, worden daarmee (vooralsnog) onvoldoende benut.

- Hunze nog onvoldoende robuust en klimaatbestendig: de waterbergingscapaciteit is nog onvoldoende afgestemd op toekomstige piekbelastingen. Ook de gehalten aan meststoffen, bestrijdingsmiddelen en medicijnresten zijn nog te hoog. Vele Europese en nationale waterdoelen worden nog niet gehaald. Aanleg van extra waterbergings- en zuiveringsmoerassen is een voorwaarde om de Hunze te transformeren in een voldoende robuust en klimaatbestendig beekdalsysteem.

- $\mathrm{CO}_{2}$-vastlegging en duurzame energie als nieuwe gebiedsmotoren: Bij de zoektocht naar functiecombinaties en ecosysteemdiensten is de waarde van het beekdalsysteem in de klimaatproblematiek nog onvoldoende benut. Natte natuur, zoals veengebieden, is belangrijk in de $\mathrm{CO}_{2}$-vastlegging. Dit biedt bedrijven kansen om tegen betaling $\mathrm{CO}_{2}$-uitstoot te compenseren met aanleg van natte natuur. Hout, riet en gras kunnen vervolgens worden ingezet als biobrandstoffen. Het probleem van veenoxidatie en energietransitie kan daarmee worden omgezet naar nieuwe verdienmodellen en economische kansen voor het Hunze-gebied.

\section{Gebruikte bronnen}

- Bilt, E. van der en M. Glastra, 1995. Hunzevisie: natuurontwikkeling in het Hunzedal en het Zuidlaardermeergebied. Uitgave Drents Landschap en Groninger Landschap. 116p.

- Eijk, Addo, 2014. Hunzevisie 2030. De Hunze: Wereldnatuur binnen handbereik. Uitgave van Het Drentse Landschap, Natuur en Milieu Drenthe, Wereld Natuurfonds, Stichting Het Groninger Landschap en Natuur en Milieu Groningen. 7p. 


\section{Oostvaardersplassen}

Na het droogvallen van zuidelijk Flevoland in 1968 werd er vanuit vliegtuigjes riet uitgezaaid als eerste stap in de ontginning. In het laagste en natste deel ontstond vanwege de komst van duizenden ruiende Grauwe ganzen echter geen monotoon rietveld, maar een mozaïek van meertjes, rietbegroeiing en ondiepe waterdoorgangen. Hier kwamen talrijke andere soorten (broed)vogels in grote getalen op af. Ook soorten die reeds lang geleden waren uitgestorven in Nederland, zoals de Grote zilverreiger en jaren later de Zeearend.

Het gebied was bestemd als industriegebied, maar toen het dreigde te verdrogen als gevolg van ontwatering vanuit de omringende polder, werd door een actiegroep succesvol gepleit voor behoud. In 1975 werd de oorspronkelijk bestemming herzien en werd een eerder aangelegde kade definitief. Hierdoor ontstond een moerasgebied van circa 3600 ha: de Oostvaardersplassen.

Door (te) intensieve begrazing van de toenemende aantallen Grauwe ganzen ontstond er een trend naar meer open water en minder natuurwaarden. Om het rietmoeras te kunnen ontlasten, was er behoefte aan graasgronden in het omliggende droge gebied. Daar konden de ganzen dan buiten de ruiperiode foerageren. Het maatschappelijk belang van de Oostvaardersplassen werd inmiddels algemeen erkend, waardoor het in 1982 mogelijk bleek om bijna 2000 ha van de aangrenzende landbouwgronden aan het moerasgebied toe te voegen. Het tracé van de geplande spoorlijn AlmereLelystad werd hier vervolgens omheen aangelegd in een zogenaamd badkuiptracé.

Om de droge zone te ontwikkelen tot de gewenste droge, grazige vegetatie werden in 1983 voor de jaarrondbegrazing Heckrunderen geïntroduceerd en een jaar later konikpaarden. Deze maatregelen konden de trend naar meer open water en minder natuurwaarden echter niet keren. Een herbezinning was op zijn plaats. Met de eerste Ontwikkelingsvisie (Polman et al., 1987) werd gestreefd naar de ontwikkeling van acht samenhangende landschapstypen, variërend van open water tot bos. Voor de moeraszone werd gekozen voor een proef met gefaseerd peilbeheer; een afwisseling van natte en droge jaren zodat de vegetatie zich periodiek zou kunnen herstellen van begrazing en erosie. Voor de droge randzone werd gekozen voor uitbreiding van het begrazingsexperiment naar de gehele zone, met een driedeling in jaarrondbegrazing, zomerbegrazing en kleine wisselweiden in de zomer. In 1992 werden vervolgens ook Edelherten uitgezet met als doel om de (vlier)struwelen te beteugelen.

In 1995 is door Rijkswaterstaat een tweede Ontwikkelingsvisie opgesteld (Van der Wildt et al. 1995), waarna het beheer in 1996 werd overgedragen aan Staatsbosbeheer. Het uitgangspunt voor het beheer werd nu 'niets doen, tenzij'. Dit betekende onder andere dat het waterpeil binnen ruime grenzen mocht variëren onder invloed van neerslag en verdamping. Ook betekende dit dat de populaties grote grazers zich mochten ontwikkelen zonder actieve vorm van beheer, zoals afschot of bijvoederen. De Oostvaardersplassen werden via een ecologische corridor verbonden met de Lepelaarplassen en in het droge gebied werden poelen, plassen en observatiehutten aangelegd. Het bieden van ruimte voor spontane natuurlijke processen bleek in de praktijk helaas niet automatisch te leiden tot het gewenste habitat voor de belangrijke Natura 2000-soorten. In de derde Ontwikkelingsvisie (Staatsbosbeheer 2008) werd de nuance daarom verlegd naar het scheppen en in stand houden van de randvoorwaarden voor natuurlijke processen.

Inmiddels was het beheer van de grote grazers al ruim tien jaar gebaseerd op minimaal ingrijpen. De populaties hadden zich daardoor snel kunnen ontwikkelen, terwijl het voedselaanbod niet wezenlijk was veranderd. In de late winter, wanneer de dieren voornamelijk op hun eigen reserves zijn aangewezen, gingen dan ook steeds meer dieren dood. Dit leidde tot (felle) maatschappelijke discussie en tot het eerste advies van de internationale beheercommissie ICMO (ICMO, 2006). De dieren zou meer beschutting moeten worden geboden en dieren in slechte conditie dienden te worden gedood; het zogenaamde 'reactief beheer'. In het tweede advies van de ICMO (ICMO, 2010) werden vervolgens aanbevelingen gedaan voor de korte, middellange en lange termijn. Op basis daarvan werden de Oostvaardersplassen in 2011 verbonden met aangrenzende bospercelen. Het advies om op langere termijn ook een robuuste ecologische verbinding te realiseren met het Oostvaarderswold, als opmaat voor een verbinding met de Veluwe, werd door de toenmalige staatssecretaris echter verworpen. Daarnaast werd besloten om dieren in een slechte conditie nog eerder te doden, zodat onnodig lijden in een vroeg stadium kon worden voorkomen; het zogenaamde 'vroeg-reactief beheer'. 
In opdracht van de staatssecretaris van Economische Zaken is in 2014 het Natura 2000-beheerplan voor de Oostvaardersplassen opgesteld (Kuil et al., 2015). Hierin gaat het vooral om de bescherming en instandhouding van 31 vogelsoorten en hun leefgebied. Het beheer van de grote grazers dient de vogeldoelstellingen te ondersteunen. In de bosrijke schil om de Oostvaardersplassen wordt het beheer op maat afgestemd op de functies natuur, bos, landschap en recreatie. De functie voor toerisme en recreatie, zoals de visuele beleving van het gebied, wordt belangrijker en de banden met de wetenschap worden verder aangehaald. Een maatschappelijke adviescommissie zal worden ingesteld met betrekking tot de discussie omtrent de grote grazers.

Samenvattend hebben de Oostvaardersplassen zich door de jaren heen ontwikkeld tot een gebied met internationale allure en faam en met een grote maatschappelijke betekenis voor ecologie, economie, recreatie, (eco)toerisme, wetenschap en educatie.

\section{Succesfactoren:}

- Internationaal kerngebied voor moerasvogels: In de Oostvaardersplassen kwamen (en komen) voor Nederlandse en Noordwest-Europese begrippen zeer hoge aantallen broedparen moerasvogels voor. Ook soorten die voorheen in Nederland zeldzaam of zelfs uitgestorven waren. Vooral tijdens droge jaren zoeken veel moerasvogels hun heil elders. De Oostvaardersplassen blijken daarmee te fungeren als een toeleveringsgebied, van waaruit andere natuurgebieden tot ver over onze landsgrenzen kunnen worden "bevoorraad". De verspreiding van sommige soorten is daardoor vergroot, waardoor de risico's voor de soort zijn verminderd.

- Inspiratiebron voor natuurontwikkeling: De natuurontwikkeling in de Oostvaardersplassen heeft bestaande beelden en opvattingen over natuur in Nederland omver geblazen. Ook in ons land bleek een natuurkwaliteit voor te kunnen komen, die voorheen werd geassocieerd met spectaculaire natuur in 'verre landen'. Het gebied trekt zelfs buitenlandse toeristen aan. De Oostvaardersplassen blijken daarmee een bron van inspiratie, wat de denkbeelden over natuur en natuurbeheer in Nederland sterk heeft beïnvloed. Het gebied wordt ook internationaal erkend, getuige de onderscheiding met het Europees diploma voor bijzondere natuur en excellent beheer door de Raad van Europa.

- Natuurlijke processen sleutel in succes: Natuurlijke processen liggen aan de basis van het ontstaan van de Oostvaardersplassen en aan de kwaliteit van de natuur toen, nu en in de toekomst. Het procesvolgend beheer is daarnaast ook kosteneffectief in vergelijking met natuurgebieden die specifiek voor bepaalde soorten worden ingericht.

- Wetenschappelijke onderzoek: De Oostvaardersplassen zijn een soort proeftuin gebleken, alwaar op relatief grote schaal kennis en ervaring konden worden opgedaan met natuurontwikkeling. Dit kon worden aangewend voor natuurontwikkeling in andere Nederlandse gebieden en is via wetenschappelijke publicaties ook beschikbaar voor natuurontwikkeling buiten onze landsgrenzen.

\section{Voorwaarden en keerzijde}

- Ecologische verbindingszones: De Oostvaardersplassen zijn een natuurgebied op 'nieuw land'. Veel grondgebonden soorten kunnen het gebied niet goed bereiken vanwege het ontbreken van een robuuste ecologische verbinding met het 'oude' land, zoals de Veluwe.

- Recreatieve mogelijkheden: De Oostvaardersplassen zijn vooral visueel beleefbaar. De mogelijkheden om het gebied ook daadwerkelijk in te trekken, zijn nog steeds beperkt. De vraag hiernaar is alleen maar toegenomen na de succesvolle bioscoopfilm over de Oostvaardersplassen 'De nieuwe wildernis'.

- Dierenwelzijn: Het beheerexperiment met grote grazers heeft, vanwege de grote aantallen hongerende dieren in de winter, verscheidene malen tot felle publieksreacties geleid, ook in de landelijke politiek. Dit ondermijnt het maatschappelijk draagvlak voor het gevoerde beheer.

- Biodiversiteitsverlies: Het toenemende aantal grote grazers leidde tussen 1997 en 2002 tot de verdwijning van $30-100 \%$ van de broedvogels van open ruigtes, weidegebieden en droge rietlanden. Ook de variatie aan planten nam af. Dit leidt tot discussie over de wenselijkheid van natuurlijk begrazingsbeheer.

- Kunstmatige natuur: De natuurlijke processen in de Oostvaardersplassen kunnen alleen bestaan doordat het beheer hiervoor de voorwaarden schept. Zo heeft het gebied een onnatuurlijke visstand, doordat het moeras hoger en daarmee geïsoleerd ligt van de wateren in het omliggende, inklinkende droge gebied. Trekvissen kunnen er niet in of uit en ook een predator als de Europese meerval kan het moeras niet bereiken. Dit leidt tot verhoudingsgewijs veel volwassen karpers en (te) weinig 
jonge vis, wat weer ten koste gaat van de visetende vogelsoorten. Het trekgedrag van vissen kan alleen plaatsvinden onder voorwaarde dat er voorzieningen, zoals vistrappen, worden aangelegd.

\section{Gebruikte bronnen:}

- ICMO, 2006. Reconciling Nature and Human Interests. Advice of the International Committee on the Management of large herbivores in the Oostvaardersplassen (ICMO). 26p.

- ICMO2, 2010. Natural processes, animal welfare, moral aspects and management of the Oostvaardersplassen. Report of the second International Commission on Management of the Oostvaardersplassen (ICMO2). 91p.

- Kuil, R., H. Janssen, S. Woudenberg, F. Vera, 2015 Natura-2000 beheerplan Oostvaardersplassen. Dienst Landelijke Gebied en Staatsbosbeheer. 211p.

- Polman, G.K.R., Schmidt-ter Neuzen, S. en Beheerscommissie Oostvaardersplassen, 1987. Ontwikkelingsvisie Oostvaardersplassen.

- Staatsbosbeheer, 2008. Ontwikkelingsvisie Oostvaardersplassen. Voorbij de horizon van het vertrouwde. $56 \mathrm{p}$.

- Wildt, C.D. van der et al., 1995. De Oostvaardersplassen natuurlijker. Advies over de verdere ontwikkeling en het beheer van de Oostvaardersplassen. Beheerscommissie Oostvaardersplassen.

- Wikipedia: https://nl.wikipedia.org/wiki/Oostvaardersplassen

\section{$\bullet$}




\section{Gelderse Poort}

\section{Gebiedsbeschrijving}

De Gelderse Poort is een ca. 6000 ha groot natuurgebied in het oostelijke rivierengebied. Het is een deelgebied van Natura 2000-gebied Rijntakken (nr. 38); de overige deelgebieden zijn Uiterwaarden van de IJssel, de Neder-Rijn en de Waal. Het rivierenlandschap van de Gelderse Poort bestaat uit de uiterwaarden naast de rivieren Waal, Rijn en een stukje IJssel, ingeklemd tussen stuwwallen van Nijmegen en Montferland. In de huidige situatie spelen natuurlijke processen een relatief grote rol. Deze processen worden aangestuurd door rivierdynamiek en begrazing. Rivierdynamiek (water en wind) geeft zandverplaatsingen, zaadverplaatsingen (rivierduin met voor NL nieuwe plantensoorten), begrazing door geïntroduceerde paarden en runderen zorgt voor verschil in vegetatie, terugzetten van successie en zelfs 'bosbeheer' door uitgezette bevers. Resultaat is een gebied dat rijk is aan gradiënten in hoogte, bodem, vocht en daarmee rijk aan standplaatsen en successiestadia. De toegankelijkheid van de Gelderse Poort verschilt van geheel toegankelijk, ook buiten de paden (Millingerwaard), tot niet toegankelijk (bijvoorbeeld Rijnstrangen). Rondom het gebied is enige economische activiteit: toerisme (campings, horeca), landbouw, en kleiwinning.

\section{Historie Gelderse Poortgebied}

In de prehistorie stroomde de Rijn in Nederland nog naar het noorden. Door het opwerpen van de stuwwallen in de laatste ijstijden is de ligging van Rijndelta naar het zuidwesten verplaatst. In de huidige begrenzing van de Gelderse Poort zijn de stuwwallen van Montferland-Nijmegen en de Veluwe dan ook duidelijk aanwezig. In deze periode hadden de morfologische processen vrij spel, en bepaalden stroming, overstromingen, opstuivingen van rivierduinen en ijsgang in sterke mate het karakter van het gebied.

In de recentere geschiedenis is ten behoeve van hoogwaterveiligheid en scheepvaart het stroombed van de rivieren aangepast en vastgelegd door graven van het Pannerdens kanaal, afsnijden van meanders, en aanleggen van dijken en kribben; daarnaast is de Rijn voorzien van stuwen, waardoor indirect ook het waterpeil in Waal en IJssel gereguleerd wordt.

De genoemde maatregelen hebben de morfologische processen ingeperkt: dijkaanleg reguleerde de ruimte voor erosie door de rivier; door verminderde ruimte voor zandafzetting vond geen rivierduinopbouw meer plaats; overstromingen werden beperkt, waardoor nu de uiterwaarden de sliblast opvangen en gaandeweg opslibben. Dit maakte het gebied vervolgens bruikbaar voor landbouw en voor grondstoffenwinning waaronder de baksteenindustrie en zand- en grindwinning. Tenslotte was in de jaren zeventig de waterkwaliteit erg laag geworden.

\section{Plan Ooievaar}

In 1986 is een ruimtelijk plan voor het oostelijke rivierengebied gepresenteerd, Plan Opoievaar, als antwoord op een ruimtelijke planvormingsprijsvraag van de Eo Wijers-stichting. In het winnende Plan Ooievaar gaven de opstellers een samenhangende visie op het rivierengebied met aandacht voor knelpunten op gebied van natuur, scheepvaart, landbouw, waterveiligheid, verstedelijking, delfstoffenwinning en recreatie. Het succes van Plan Ooievaar volgde uit de geïntegreerde aanpak van al deze problematiek waarbij een nieuwe structuur voor het rivierengebied werd voorgesteld met binnen- en buitendijks andere ordeningsprincipes: buitendijks bepalen rivierkundige en natuurlijke processen wat er gebeurt en binnendijks is verdere landbouwkundige optimalisering sturend. Aan het succes droeg ook de wijze van uitwerking van het plan bij, in een generiek concept dat later voor specifieke plekken kon worden uitgewerkt. Ten slotte speelden mee de brede samenstelling van de projectgroep en een periode waarin ecosysteemdenken meer geaccepteerder begon te raken. De publiciteit voor het winnende ontwerp van de prijsvraag heeft vervolgens gezorgd dat verdere ideeënvorming werd gestimuleerd, zowel door overheden als LNV en RWS en door ngo's als WNF met het plan Levende Rivieren in 1992.

De herinrichting van de Gelderse Poort is een van de concrete uitwerkingen van Plan Ooievaar. Met lokale belanghebbenden is een geïntegreerd plan opgezet, waarbij buitendijks natuurgebieden werden ontwikkeld en binnendijks de landbouw werd gestimuleerd. De natuurontwikkeling buitendijks wordt in 
samenhang bekeken met waterveiligheid, scheepvaart en economisch-maatschappelijke activiteiten als delfstoffenwinning, recreatie en toerisme.

Begin jaren negentig startte het werk in de uiterwaarden met de aankoop van buitendijkse landbouwgrond rond het Millingerduin. De volgende stap was het reliëfvolgend ontkleien van de opgeslibde uiterwaarden door de baksteenindustrie, een nieuw concept, waarbij zo veel mogelijk de oude zandige ondergrond met geulen en oevers weer werd blootgelegd. De hoogwaters van 1993 en 1995 laten het belang van verruiming van het rivierbed bij hoogwater zien, en stimuleren de ontkleiing. Ook blijkt dan dat rivierdynamiek nog echt aanwezig is: tijdens piekafvoeren treedt weer oevererosie en rivierduinvorming op. In de verschillende gebieden in de Gelderse Poort worden de plannen uitgewerkt via verlaging van de oppervlakte, aanleg van nevengeulen, hoogwatergeulen, plassen en moeras. De ingrepen leverden nieuwe pionierstadia op en flora en fauna volgden snel. Intensieve contacten met de lokale bevolking zorgden uiteindelijk ook voor een groot lokaal draagvlak.

\section{Resultaten}

De afgelopen twintig jaar is er sprake van een sterke toename van rivierbegeleidende flora en fauna. De plekken met zanddynamiek zoals de rivierduinen zijn daarin uniek. Op pionierssituaties langs laaggelegen zand- en slikoevers komen nu zeldzame plantensoorten voor als Riempjes en Polei. Soorten van stroomdalgraslanden, overstromingsgraslanden en ruigten en zoomflora laten eveneens een toename zien. Zachthoutooibossen zijn ook in areaal toegenomen; hardhoutooibossen nog beperkt. Qua fauna zijn vooral de terugkeer van bever en otter (beide geherintroduceerd in Nederland) een succes, daarnaast komen in de Gelderse Poort nu ook weer dassen en ringslangen voor. Broedvogels van slikkige oevers, moerasgebieden en ruigtes zijn toegenomen, en de verbetering van de waterkwaliteit heeft voor herstel van aquatische soorten gezorgd.

\section{Toekomstverwachting}

In verband met de hoogwaterveiligheid zal permanent aandacht blijven voor voldoende ruimte voor de rivier. In de Millingerwaard zijn hiervoor nieuwe vergravingen gestart. Via het plan 'Een waaier van geulen' wordt wederom aansluiting gezocht bij de riviermorfologie in de vorm van het uitgraven van hoogwatergeulen. Aandacht in de planvorming blijft nodig voor het lokale en regionale draagvlak. Door de betrokken lokale bevolking wordt nu de dialoog met SBB gestart om ook voldoende wandelmogelijkheden te behouden.

\section{Succesfactoren}

Ecologische succesfactoren:

- Rivierdynamiek kan de ruimte krijgen en veroorzaakt overstromingen en zandverplaatsingen (erosie en sedimentatie) waardoor reliëf verandert en er weer pionierssituaties ontstaan.

- Weinig natuurwaarden aanwezig vóór ontwikkeling; omvorming landbouw in natuur.

- Rivierwater is drager van zaden over grote afstanden.

- Voorkomen van bevers, dassen, zwarte sterns, pionierplanten als Riempjes en Polei.

- Groot gebied waardoor kuddes grote grazers mogelijk zijn en zorgen voor variatie in vegetatiestructuur.

Maatschappelijke succesfactoren voor natuurontwikkeling:

- Er was behoefte aan integrale oplossing voor meerdere problemen, waaronder landbouw, scheepvaart, grondstofwinning en natuur. Er waren op meerdere vlakken ongewenste situaties:

- natuur: o.a. vervuilde rivier, geen natuur over gradiënten, wel potentiële dynamiek;

- landbouw: goede gronden maar in kommen te klein verkaveld;

- waterstaat: veiligheid hoogwater

- grondstoffen aanwezig: klei, zand;

- sterke betrokkenheid natuurorganisaties, natuurliefhebbers en omwonenden.

- Tijdgeest en visie: Plan Ooievaar, het ontwerp van een brede groep mensen die een geïntegreerd plan voor ruimtelijke ontwikkeling op wisten te zetten.

- Omvorming van agrarische gebieden in natuur.

- Verbetering waterkwaliteit.

- Economische mogelijkheden die financiële drager konden zijn: zand-, klei- en grindwinning.

- Samenwerking van meerdere actoren: RWS, ARK, WNF, SBB, industrie, horeca en lokale bevolking. 
- Bereidheid tot overleg tussen alle actoren.

\section{Voorwaarden en keerzijde}

- Teruggekeerde dynamiek blijft relatief beperkt: ijsgang treedt niet meer op en slibafzettingen in de uiterwaarden worden niet vaak meer weggeërodeerd. Waar dit ongewenste situaties oplevert, wordt beheer ingezet. Voor hoogwaterveiligheid bijvoorbeeld moeten doorstroomprofielen ruim genoeg blijven:

- Te hoge of te dichte opstanden worden soms gekapt. Hierdoor ontstaan ook weer kansen voor natuurontwikkeling.

- Opgeslibte uiterwaarden worden weer vergraven; ook dit levert weer nieuwe pionierssituaties.

- Aandacht voor breed actorenoverleg blijft onverminderd belangrijk, met name bij nieuwe ontwikkelingen om alle belangen zo goed mogelijk gezamenlijk in te vullen.

- Verschil in toegankelijkheid voor bezoekers: Millingerwaard open, ook buiten de paden; Rijnstrangen niet toegankelijk.

\section{Gebruikte bronnen}

- Eo Wijers Stichtitng (1986). Juryrapport.

- Kersten, P.H., M.J.J. Eekhout, R.P. Kranendonk, K.R. de Poel \& J.J.N. Geenen (2001). Op zoek naar magische momenten in de ruimtelijke planvorming. Deskstudie voor de etudes uit de nota 'Natuur voor mensen, mensen voor natuur'. Alterra-rapport 366, Alterra, Wageningen.

- Klink, A. (1998). Dood hout, levende rivieren. Over ongewervelden, natuurontwikkeling, riviermorfologie en klimaat. In: Nieuwe Wildernis, voorjaar 1998, p20-23.

- Kurstjens, G. \& B. Peters (2012). Rijn in Beeld, Ecologische resultaten van 20 jaar natuurontwikkeling langs de Rijntakken

- Plan Ooievaar. http://www.wildernis.eu/chartroom/?nav0=projecten\&nav1=Plan\%200oievaar\&nav2=Plan\%200oievaar\%20tekst

- Stichting Ark (2015). https://www.ark.eu/over-ark/ark-organisatie/hoe-het-begon 


\section{De duinen van Noord-Holland}

\section{Introductie}

Dynamisch beheer van de duinen betekent enerzijds dat zee en wind de ruimte hebben om zand en sediment te verplaatsen en anderzijds wordt er geprobeerd om het natte en droge deel van de kust met elkaar te verbinden via de waterhuishouding en de morfologie (Rijkswaterstaat and STOWA, 2015). Op deze wijze vormen de zee, het strand, de duinen, de binnenduinrand en het land zo veel mogelijk een dynamisch geheel. Wanneer dit type beheer van de duinen succesvol is, kan er een natuurlijker kustlandschap met een grotere diversiteit aan habitats, flora en fauna ontstaan. De duinen zijn ook belangrijk voor de bescherming van het achterland tegen overstromingen en zijn een belangrijke buffer van zoetwater. Hoeveel dynamiek er in een duingebied gerealiseerd kan worden, hangt daarom af van het watergebruik in en rondom de duinen en de maatregelen die (natuur)terreinbeheerders, Rijkswaterstaat en het waterschap in en rondom het betreffende duingebied nemen.

\section{Morfologische dynamiek in de Noord-Hollandse duinen}

De zandige kust van Noord-Holland strekt zich uit van Huisduinen bij Den Helder tot aan de noordelijke havendam van IJmuiden (uitgezonderd de Hondsbossche en Pettemer Zeewering), de westkust van Texel (Broos, M., et al., 2012) en ten zuiden van het Noordzeekanaal tot aan de Amsterdamse Drinkwater Duinen. Vanaf 1990 worden door Rijkswaterstaat vooroeversuppleties uitgevoerd om de huidige kustlijn te handhaven langs de Nederlandse Kust. Strandsuppleties werden al gedaan vanaf de jaren zeventig. Het voordeel van vooroeversuppleties is dat ze veel goedkoper zijn (persoonlijke mededeling RWS). Het zand (afkomstig uit de diepe Noordzee) wordt neergelegd op het strand of vlak voor de kust. Een deel van het gesuppleerde zand stuift naar de achterliggende duinen op plaatsen (kerven, stuifkuilen) waar dat mogelijk is. De waterkerende functie van de duinen in Noord-Holland wordt in de gaten gehouden door de waterschappen (Rijnland, Hollands Noorderkwartier). Het waterschap doet dit via vergunningen; op deze wijze worden activiteiten die de waterkerende functie zouden kunnen beïnvloeden onder controle gehouden. Tevens wordt de conditie van het duin (de dimensionering van het waterkerende deel) in de gaten gehouden. Als bijvoorbeeld door storm de waterkerende functie onder de norm komt, dan zal het waterschap dit deel van de duin moeten herstellen conform de Waterwet (zand aanbrengen). Het beheer en onderhoud van het waterkerende deel van de duinen door de waterschappen is vanaf 1990 'passiever' geworden in vergelijk met daarvoor. Men geeft ruimte aan natuurlijke processen, zolang de waterkerende functie aan de norm voldoet. Dit kan omdat Rijkswaterstaat aanvullende vooroever- en strandsuppleties uitvoert.

De waterkerende functie wordt altijd zo dicht mogelijk langs de zeezijde gedefinieerd en omvat alleen bij smalle duinstroken het gehele duingebied. De dimensionering van de waterkerende functie wordt bepaald door het totale volume zand dat nodig is om golfafslag op te vangen plus de hoeveelheid zand die nodig is om na de afslag het binnenland te beschermen. Na een storm zal bij lagere waterstanden het opbouwproces van het duin door de wind opnieuw beginnen. In het verleden werden stuifgaten direct dichtgemaakt wanneer deze ontstonden. In de recente beheerplannen van beide waterschappen wordt er nu meer ruimte geboden voor het ontstaan van stuifkuilen in de bredere duinstroken. Voor de waterschappen blijft het beplanten van smalle duinstroken met helmgras essentieel voor de waterkerende functie. Bij bredere duingebieden is een bepaalde mate van verstuiving door het weghalen van helmgras wel een mogelijkheid. Voor het uitoefenen van zijn beheertaak in de duinen is het voor waterschap niet noodzakelijk om de duinen in eigendom te hebben. De aangewezen onderhoudsplichtige, meestal de eigenaar van de grond, moet het onderhoud uitvoeren op basis van de Keur en de legger van het waterschap.

\section{Hydrologische dynamiek in de Noord-Hollandse duinen}

Naast het (gedeeltelijk) herstel van morfologische dynamiek is het herstel van dynamiek in de waterhuishouding een belangrijke factor die de natuurlijkheid van het duinlandschap bepaald. Er zijn in het verleden verschillende ontwikkelingen geweest die de dynamiek in de waterhuishouding in de duinen hebben beïnvloed. In 1853 is men begonnen met de winning van drinkwater (Geelen, L., et al., 2001). Toen deze winning het natuurlijk neerslagoverschot oversteeg, trad er verdroging van de duinnatuur op. Vanaf 1957 wordt in de Noord-Hollandse duinen (Amsterdamse Waterleidingduinen bij 
Zandvoort) Rijnwater geïnfiltreerd waardoor er minder grondwater hoeft gewonnen te worden. Dit water was nutriëntrijker dan natuurlijk grondwater en leidde tot eutrofiëring van duinvalleien. Mede daarom wordt dit water eerst voorgezuiverd voordat het water geïnfiltreerd wordt. Ook zijn door natuurbeheerders maatregelen genomen om de effecten van de eutrofiëring tegen te gaan.

Tegelijkertijd is de waterkwaliteit (nutriënten) van het Rijnwater nu veel beter dan 20 jaar geleden (CBS et al, 2012; RIWA, 2007), maar het is nog altijd nutriëntrijker dan grondwater onder de duinen. In de Waterleidingduinen bij Zandvoort wordt op dit moment jaarlijks circa 60 miljoen $\mathrm{m}^{3}$ drinkwater teruggewonnen uit 50 miljoen $\mathrm{m}^{3}$ infiltratiewater en $10 \mathrm{~m}^{3}$ neerslag. Voor 2006 was de maximale capaciteit 80 miljoen per jaar. De waterwinning is verkleind om verdrogingseffecten in de natuur te verminderen. Het herstel van de grondwaterstanden leidde echter ook tot natschade/wateroverlast in aanliggende woonwijken (Bloemendaal) en landbouwgebied (bollen). Het ruimtegebruik rondom de duinen beperkt dus ook de mogelijkheden tot herstel hydrologische dynamiek.

\section{Natuurbeheer en dynamisch kustzone beheer in de Noord-Hollandse duinen}

De drinkwaterbedrijven (PWN en Waternet) en Staatsbosbeheer beheren de meeste duingebieden in Noord-Holland (Tabel 1). Daarnaast beheren Landschap Noord-Holland, Natuurmonumenten en sommige gemeenten (bebouwde omgeving) ook stukken duin. De beheerders zijn niet altijd de eigenaars van alle grond in de duinen. Alle duinen in Noord-Holland zijn Natura 2000-gebied.

Tabel 1 Geschatte verdeling van natuurbeheer in duingebied van Noord-Holland uitgedrukt in oppervlakte natuurterrein onder beheer. Oppervlakten zijn geschat op basis van de natuurkaart vanNaturalis Biodiversity Centre.

\begin{tabular}{ll} 
Natuurterreinbeheerder & Geschat op pervlak in duingebied (afgerond) \\
Staatsbosbeheer & \pm 4900 ha $(24 \%)$ \\
\hline Landschap Noord-Holland & \pm 600 ha $(3 \%)$ \\
\hline Natuurmonumenten & \pm 1000 ha $(5 \%)$ \\
\hline Drinkwaterbedrijf PWN & \pm 8200 ha $(41 \%)$ \\
\hline Waternet & \pm 3400 ha $(17 \%)$ \\
\hline Totaalareaal beschermd duingebied in NH & \pm 20.000 ha \\
\hline
\end{tabular}

Naast hydrologische en morfologische maatregelen hebben begrazing, afplaggen, herintroductie van soorten en recreatie invloed op natuurlijke dynamiek in de Noord-Hollandse duinen, die door de natuurterreinbeheerder kunnen worden beïnvloed.

Project Noordwest Natuurkern (2014), Project Bokkedoorn (2012)

Project Noordwest Natuurkern (400 ha) ligt in het Nationaal Park Zuid-Kennemerland op het terrein van PWN en is in samenwerking met Natuurmonumenten uitgevoerd. Er zijn vijf grote sleuven (100150 meter breed) in de zeereep gegraven en vijf achterliggende duincomplexen zijn ontdaan van hun begroeiing en wortellaag. Zo kunnen duinen weer gaan stuiven. Je ziet hier wel paraboolduinen ontstaan. Hoogheemraadschap Rijnland verlegde speciaal voor dit PWN-project de lijn van de primaire zeekering in de duinen meer naar het oosten, daarbij rekening houdend dat de veiligheid van het achterland altijd gewaarborgd bleef.

\section{Project De Kerf (1997)}

Project De Kerf' was het eerste voorbeeldproject voor 'dynamisch kustbeheer' in Nederland. Eind 1997 is een 50 meter breed, maar ondiep gat in de zeeduinen tussen Bergen aan Zee en Schoorl gegraven. Dit werd uitgevoerd door Staatsbosbeheer. Hierdoor kan de zee de achterliggende duinvallei binnenstromen, maar alleen bij extreme waterstanden. De Kerf is tot stand gekomen dankzij een samenwerkingsverband tussen de Stichting Duinbehoud, Staatsbosbeheer, Rijkswaterstaat, Hoogheemraadschap Hollands Noorderkwartier en NV PWN Waterleidingbedrijf Noord-Holland. In 2003 is het project geëvalueerd. In de periode 1997-2003 is de Kerf ongeveer 30 keer volgelopen met zeewater. In de geplagde vallei kwelde zoet water op, wat tot mooie zoet-brakovergangen leidde. Soorten zoals Parnassia en de Moeraswespenorchis vestigden zich snel. Aanvankelijke angst onder de bevolking voor overstromingen maakte later plaats voor enthousiasme. Na 2003 werden overstromingen steeds zeldzamer, omdat de opening naar zee volstoof met zand. Tijdens een hevige storm in de winter van 2007-2008 drong het water voor het laatst de vallei binnen. Niettemin bleven 
zich nieuwe planten zich vestigen die representatief zijn voor brakke omstandigheden. Verder is er grote dynamiek van stuivend zand en staat er in natte perioden, veel vaker dan voor de ingreep, zoet water in de achterliggende duinvallei (Löffler, M. 2013).

\section{Succesfactoren:}

- Uit evaluaties (De Kerf) blijkt: Mensen vonden elkaar en gingen ervoor, er was chemie. Dan gebeurt er iets. Zie je vaker bij grote dingen/projecten;

- Het herstel van natuurlijke dynamiek in de duinen is ook van belang voor de waterkwaliteit van drinkwater. In de duinen, die in het bezit zijn van drinkwaterbedrijven, is het natuurbeheer mede financierbaar door verrekening van het natuurbeheer in de prijs van het drinkwater.

\section{Voorwaarden en keerzijde}

- Er is zo'n 20 jaar hersteltijd nodig voor de vegetatie wanneer een kerf in de zeereep wordt aangelegd.

- Met het aanleggen van kerven, door de verwijdering van zand, verwijder je ook mogelijk een deel van de zaadbank. Dit kan het herstel van de natuurlijke vegetatie ook beperken.

- Bij maatregelen in het kader van de PAS zijn veel verstuivingsmaatregelen in het duin nodig. Het realiseren van stuifkuilen vergt een vergunning van het waterschap en het duinbeheer mag niet ten koste van de waterveiligheid gaan.

- Je moet als natuurbeheerder van dynamisch duinbeheer continu in dialoog blijven met de omgeving om het gerealiseerde draagvlak te blijven houden. Bijvoorbeeld: Dennenbos omvormen tot duinbossen is belangrijk voor de natuur, maar dat wordt niet altijd zo beleefd door alle terreinbeheerders.

\section{Gebruikte bronnen}

- Rijkswaterstaat and STOWA, 2015. Dynamisch Kustbeheer - Delta Proof - Samen Klimaatbestendig. [cited 2015 08-10-2015]; Available from: http://www.dynamischkustbeheer.nl.

- Broos, M., et al., 2012. Beleidsnota Waterkeringen 2012-2017: Van waterkeringen naar waterveiligheid, Afdeling Waterkeringen \& Wegen, Hoogheemraadschap Hollands Noorderkwartier: Heerhugowaard.

- Geelen, L., et al., 2001. De Duinen gaan nat! Natte toekomst: uitdagingen voor beleid, beheer en onderzoek. Landschap, 2001. 18(3): p. 227-237.

- CBS, PBL, and Wageningen UR, 2012. Compendium voor de Leefomgeving - Vermesting in grote Rivieren 1970-2011(indicator 0249, versie 09, 12 september 2012). . 2012; Available from: http://www.compendiumvoordeleefomgeving.nl/indicatoren/nl0249-Vermesting-in-groterivieren.html?i=26-79.

- RIWA, 2007. 30 jaar Rijnwater Deel 1 - Algemene parameters, in RIWA A. Bannink, Editor. 2007, Vereniging Rivierwaterbedrijven (RIWA). p. 52 p.

- Naturalis Biodiversity Centre, et al.2015 Natuurkaart - Op stap in de mooiste natuurgebieden van Nederland. [cited 2015 08-10-2015]; Available from: http://natuurkaart.nl/.

- Löffler, M. 2013. Hoe gaat het toch met de Kerf? [cited 2015 09-10-2015]; Available from: http://www.dynamischkustbeheer.nl/documents/dynamischkustbeheer/documents/hoe-gaat-hettoch-met-de-kerf.pdf. 


\section{Geuldal}

De Geul vormt van nature de verbinding tussen de Duitse Eifel en de Belgische Ardennen enerzijds en de Nederlands-Belgische Grensmaas anderzijds. De Geul is relatief onontgonnen, en vormt een van de meest natuurlijke beken in Nederland, met hoge stroomsnelheden. Waar zij de ruimte krijgt, ontstaan hoge steilranden en een grote dynamiek. Het Beneden-Geuldal maakt deel uit van het veel grotere Natura 2000-gebied Geuldal.

Het Geuldal wordt gekenmerkt door grote hoogteverschillen. Van de hoge vlakke plateaus, via de hellingen naar de vele dalen. Deze opbouw maakt het gebied bijzonder gradiëntrijk. De dalen zijn voedselrijk, nat tot vochtig, met een afwisseling van graslanden en bossen, waaronder bron- en broekbossen. Op de hellingen zijn twee zones te onderscheiden. De onderste zone is voedselrijker, vochtig en kalkrijk, door naar beneden gegleden kalk en geërodeerde löss. De bovenste helft van de hellingen is kalkarm, voedselarmer en droog. Op de hellingen kan het moedermateriaal kalk dagzomen. Hier vind men groeven en kalksteenwanden. Waar oude afzettingen op de hellingen liggen, die waterkerende lagen vormen, kunnen bronnen ontstaan.

\section{Beekdalontwikkelingsproject Beneden-Geuldal}

In het Beneden-Geuldal is in 1995, als eerste deel van het Geuldal een beekdalontwikkelingsproject van start gegaan. Initiatief hiervoor kwam vanuit de Provincie Limburg. Zij werkte daarbij nauw samen met Waterschap Roer en Overmaas, gemeenten Valkenburg en Meerssen, ministerie van LNV en Zuiveringsschap Limburg. Beheer werd gedaan door Stichting Het Limburgs Landschap, Stichting Ark en Stichting DOEN. Het beneden-Geuldal project beoogd een verandering in een natuurlandschap, waar de Geul ongestoord meandert, vissen ongehinderd kunnen migreren binnen het gehele bekensysteem, kuddes paarden en runderen vrij grazend door het dal trekken en het oerbos op de hellingen weer terugkeert. Ook de spontane komst van de bever is een nieuwe ontwikkeling (ARK 25 jaar). Sinds 2014 werkt ARK aan het project 'Geuldal, catwalk voor Europese topnatuur'. Dit project is mogelijk gemaakt dankzij een bijdrage uit de extra trekking van de Nationale Postcode Loterij. Hierin wordt nauw samengewerkt met de Waalse natuurorganisatie Natagora.

\section{Natuurlijke beekdalprocessen}

Belangrijke beekdaleigen processen als het omvallen van bomen, hellingval en de bouw van beverdammen zorgen voor een snelle destabilisering van het oeverbed. De omgevallen bomen zetten aan tot vorming van grindeilandjes, nieuwe nevengeulen en hoogwaterkolken De beek krijgt een gevarieerd en breed stroombed, met verschillende stroomsnelheden. Elk jaar kalven spontaan nieuwe hoge steilranden af en verandert de rivier van plaats. Op de lage eilanden en binnenbochten groeit weelderig ooibos met wilgen en elzen, dat zich spontaan op het open substraat vestigt. Dit wordt na verloop van tijd weer weggespoeld of ondermijnd, waardoor grote hoeveelheden klinkhout weer onderdeel van het beeksysteem gaan uitmaken. Karakteristieke flora en fauna van de Geul keert terug. IJsvogels vestigen zich in de steilranden, moesdistel en kleine kaardenbol massaal op de grindbanken en zandafzettingen en in nieuw ontstane erosiekolken keren libellen en amfibieën terug. (Levende Natuur).

Waar geen bebouwing of infrastructuur beschermd hoefde te worden, mocht de Geul weer vrijelijk afkalven. Overtollige beschoeiingen zijn verwijderd. Vanuit grondaankoopregelingen voor de realisering van de EHS konden gronden langs de Geul worden aangekocht. Het beekdal in Meerssenerbroek en De Dellen wordt integraal begraasd door paarden en runderen. Begrazing zonder scheiding tussen dal met graslanden, de kalkhellingen met bossen en de zure plateaus. Na twintig jaar jaarrond begrazing is er een rijke voorjaarsflora ontstaan. Via natuurlijke begrazing ontwikkelen zich natuurlijke bosranden en struweelrijke graslanden (25 jaar ARK).

\section{Medegebruik waterwinning en waterberging}

Een natuurlijke beek heeft een grote waterbergende capaciteit. In natte tijden lopen oude geulen vol en gaan meestromen tot uiteindelijk in de dal-vlakte een brede stroom ontstaat. Het rapport "Bergen bij de Bron" van Bureau Stroming presenteert deze vorm van waterberging als natuurlijk alternatief voor (of aanvulling op) kunstmatige regenbuffers in het heuvelland (25 jaar ARK Geuldal _ ARK Natuurontwikkeling.htm). Binnen het gebied liggen nu 11 regenwaterbuffers. Deze vangen tijdelijk het 
hemelwater op, zodat (modder- en) wateroverlast in de stroomafwaarts gelegen gebieden wordt tegen gegaan.

Beekherstel kan een bedreiging vormen voor de drinkwaterwinning (Witteveen en Bos, 2012). Infiltratie van vervuild oppervlaktewater in de nabijheid van de winning kan een probleem vormen voor de microbiologische kwaliteit. Alleen als de oppervlaktewaterkwaliteit goed is, is er geen bedreiging. Hiervoor moeten bijvoorbeeld riooloverstorten en lozingen van RWZI's bovenstrooms worden beëindigd.

In verband met de waterwinning Roodborn beschermt Waterleiding Maatschappij Limburg (WML) het intrekgebied waarop zich onder meer kalkgraslanden bevinden. Voor deze kalkgraslanden geldt dat de mogelijkheden voor optimalisering van het beheer gezocht moeten worden binnen de beperkingen die de waterwinning met zich meebrengt. Begrazing en verwijderen van de lösslaag voor kalkgrasontwikkeling is daarom niet toegestaan.

Biodiversiteit in de beek.

Bijzondere vissen zoals beekprik, beekdonderpad en forel zijn karakteristiek voor grindbeken, zoals de Geul. Ze hebben een beekbodem nodig van los zand of grind voor hun voortplanting. Daarin maken ze kuiltjes voor de afzetting van eieren. In de Geul is het grind op veel plaatsen aan elkaar gekoekt door organisch slib (watervervuiling). Het plaatselijk lostrekken van de beekbodem met een kraan zorgt voor betere omstandigheden.

In de Geul leven beekforellen. Jaarlijks bijzetten van forellen was noodzakelijk, omdat in de Geul geen voortplanting meer plaatsvond. Inmiddels paaien er met succes weer forellen. Uit onderzoek van het waterschap blijkt dat niet alleen beekforel, maar ook andere vissoorten en waterinsecten van het schonere water profiteren. De inspanningen voor (riool)waterzuivering en natuurlijk beekbeheer beginnen hun vruchten af te werpen. Nu ook in het bovenstroomse deel van de Geul in Wallonië meer aandacht komt voor waterzuivering, is de verwachting dat deze positieve trend in de toekomst doorzet.

In de Geul komt ook de bedreigde beekdonderpad voor. Alleen de stuw nabij de Grootte molen bij Meerssen voorkomt dat de soort contact maakt met de rivierdonderpad. Onduidelijk is of de soorten elkaar beconcurreren of hybridiseren. Voordat effecten duidelijk zijn, en voordat verdere habitatuitbreiding van de beekdonderpad is bewerkstelligd, moet dus de Grootte Molen niet vis-passeerbaar worden gemaakt!

\section{Succesfactoren}

- Stromend water en meanderend karakter van de Geul, en de ruimte om vrij te meanderen.

- Zeer gradiëntrijk gebied. Hoogte, kalkgehalte, nutriëntenrijkdom en droog/nat. Optreden kwel.

- Aanwezigheid slecht doorlatende lagen op hellingen waardoor bronnen ontstaan.

- Verbetering waterkwaliteit.

- Compleet beekdalsysteem met bronnen, beken en rivier. Plateaus, hellingen en dalen.

- Groot gebied. Lengte geul is $50 \mathrm{~km}$.

- Soorten die hebben geprofiteerd: Spaanse vlag, vliegend hert, hazelmuis, wilde kat, bever, otter, stroomminnende vissoorten (elrits, barbeel, kopvoorn, beekdonderpad, beekprik).

- Meekoppelen met natuurlijke waterberging.

- Goede afstemming beheer en beleid. Provincie heeft beherende partijen vrijgelaten, gebaseerd op vertrouwen en resultaten.

- Gelden beschikbaar vanuit beleid voor aankoop gronden, Postcode Loterij.

- Veel aandacht voor communicatie naar grotere publiek. Voorlichting, excursies, films, etc.

\section{Voorwaarden en keerzijde}

- Doorsnijding met wegen: Het verkeer vormt een van de belangrijkste onnatuurlijke doodsoorzaken van bevers.

- Opheffen knelpunten vismigratie is een bedreiging voor beekdonderpad.

- Voortgang project is afhankelijk van voortgang aankoop van gronden.

- Waterkwaliteit moet verder verbeterd worden. 
- Vele verschillende eigenaren, inclusief groot bovenstroomsgebied in Belgie.

\section{Gebruikte bronnen}

- Peters, B. J. de Groot \& W. Coenen. 1997. De Geul baant zich een natuurlijk beekdal. De Levende natuur 98-4, p 147-148.

- https://www.ark.eu/nieuws/2014/paaibedden-beekforel-opschudden-de-geul

- Overmars, W., W. Helmer \& G. Litjens, 1996. Stroming bv. Studie in opdracht van de Provin- cie Limburg. ISBN 9074647316

- Beekdalontwikkeling Beneden Geul, deel 1, hoofdrapport

- Beekdalontwikkeling Beneden Geul, deel 2, locatiestudies

- Beekdalontwikkeling Beneden Geul, deel 3, onderzoeksrapporten

- Witteveen+Bos, 2012. Gebiedsdossier winning Roodborn. Provincie Limburg, Witteveen+Bos, Maastricht. 


\section{Bijlage 2 Bronnen kaartgegevens}

\begin{tabular}{|c|c|c|c|c|}
\hline Criterium & bestandsnaam kaart & jaartal bestand & bronhouder bestand & meer info \\
\hline Watersysteemeenheden & aquarein20090723 & 2009 & Rijkswaterstaat, Meetkundige dienst & Van Boekel et al., 2013. \\
\hline Buitendijks in zeekleigebied & LBK.gbd: LBK_Secties & 2015 & Alterra Wageningen UR & Van Delft et al. 2015. \\
\hline Dalen in Heuvelland & LBK.gbd: LBK_Secties & 2015 & Alterra Wageningen UR & Van Delft et al. 2015. \\
\hline Beekdalen & LBK.gbd: LBK_Secties & 2015 & Alterra Wageningen UR & Van Delft et al. 2015. \\
\hline $\begin{array}{l}\text { Laaglandrivieren (stroom- } \\
\text { bedding en waarden) }\end{array}$ & LBK.gbd: LBK_Secties & 2015 & Alterra Wageningen UR & Van Delft et al. 2015. \\
\hline Stromende Wateren & Watertype_2009_11 Lijn en Vlak & 2009 & PBL, Alterra Wageningen UR & Puijenbroek \& Clement, 2010 \\
\hline Stuifzandgebieden & LBK.gbd: LBK Secties & 2015 & Alterra Wageningen UR & Van Delft et al. 2015. \\
\hline Kale bodem & LGN7 & 2012 & Alterra Wageningen UR & Hazeu et al., 2014 \\
\hline Kwel & $\begin{array}{l}\text { FLF_MEAN_19980101- } \\
\text { 20070101_MM_L1.ASC }\end{array}$ & $1998-2007$ & $\mathrm{NHI}$ & http://www.nhi.nu/nieuws bosatlas.html \\
\hline Restveengronden & LBK.gbd: LBK_Secties & 2015 & Alterra Wageningen UR & Van Delft et al. 2015. \\
\hline Veenweide & LBK.gbd: LBK_Secties & 2015 & Alterra Wageningen UR & Van Delft et al. 2015. \\
\hline Waterpeilfluctuaties & $\begin{array}{l}\text { PKS_Effect_Wateroverlast_Gemid } \\
\text { delde Hoogste (en laagste) } \\
\text { Grondwaterstand_Huidig_V9_to }\end{array}$ & $\begin{array}{l}\text { "huidige } \\
\text { periode" }\end{array}$ & Alterra Wageningen UR en anderen & \begin{tabular}{|l|} 
Klimaateffectenatlas: \\
http://www.ruimtelijkeadaptatie.nl/nl/klimaate \\
ffectatlas
\end{tabular} \\
\hline Voorkomen bever & s1337_1km_bever & $2007-2011$ & NDFF, EU rapportage VHR & http://www.ndff.nl/ \\
\hline Relief & AHN2 (resolutie $25 * 25 \mathrm{~m} 2$ ) & $2007-2012$ & Rijkswaterstaat en de waterschappen & http://www.ahn.nl/index.html \\
\hline Relief & AHN2 (resolutie $25^{*} 25 \mathrm{~m} 2$ ) & $2007-2012$ & Rijkswaterstaat en de waterschappen & http://www.ahn.nl/index.html \\
\hline Variatie in landschapstypen & LBK.gbd: LBK_Secties & 2015 & Alterra Wageningen UR & Van Delft et al. 2015. \\
\hline Kalk in bodem & Bodem_nl (raster Jan Clement) & vigerend 2004 & Alterra Wageningen UR & Bodemkaart \\
\hline landbouw & LGN7 & 2012 & Alterra Wageningen UR & Hazeu et al., 2014 \\
\hline Productiebos & $\begin{array}{l}\text { IMNAB20141014_Beheergebied_2 } \\
015\end{array}$ & 2014 & IPO, provincies & $\begin{array}{l}\text { https://www.portaalnatuurenlandschap.nl/the } \\
\text { mas/productencatalogus/kaarten/landelijke- } \\
\text { beheertypenkaart/ }\end{array}$ \\
\hline Waterberging & CM_WATERB & publicatie & Alterra Wageningen UR & De Knegt et al., in prep \\
\hline Wateroverlast & \begin{tabular}{|l} 
PKS_Effect_Wateroverlast_1:100 \\
Bui_Huidig_v3_to_uit
\end{tabular} & $\begin{array}{l}\text { "huidige } \\
\text { periode" }\end{array}$ & Alterra Wageningen UR en anderen & $\begin{array}{l}\text { Klimaateffectenatlas: } \\
\text { http://www.ruimtelijkeadaptatie.nl/nl/klimaate } \\
\text { ffectatlas }\end{array}$ \\
\hline Waterkeringen & $\begin{array}{l}\text { Segmenten_NEDERLAND_EINDSC } \\
\text { ORE (dijken en duinen) }\end{array}$ & 2013 & $\begin{array}{l}\text { Inspectie Leefomgeving en Transport } \\
\text { (2013) }\end{array}$ & CBS et al., 2014 \\
\hline Drinkwaterwinning & CM_DRINKW & publicatie & Alterra Wageningen UR & De Knegt et al., in prep \\
\hline Recreatie & CM_RECR & publicatie & Alterra Wageningen UR & De Knegt et al., in prep \\
\hline $\begin{array}{l}\text { Daar Moet Ik Zijn, de meest } \\
\text { aantrekkelijke gebieden. }\end{array}$ & $\begin{array}{l}\text { DMIZsp_dis; gedigitaliseerde fig } \\
\text { 13, pag } 51 \text { rapport }\end{array}$ & 2006-2010 & Alterra Wageningen UR & Goossen et al., 2011. \\
\hline $\begin{array}{l}\text { Aanleg Natuurvriendelijke } \\
\text { oevers }\end{array}$ & \begin{tabular}{|l|} 
Tabel: Copy of database nvo.xlsx - \\
gekoppeld aan \\
Watertype_2009_11 Lijn en Vlak
\end{tabular} & dec-14 & $\begin{array}{l}\text { Waterschappen bewerkt door Alterra } \\
\text { Wageningen UR }\end{array}$ & $\begin{array}{l}\text { Notitie Van Boekel: factsheets van de } \\
\text { waterschappen (december 2014, } \\
\text { www.waterkwalteitsportaal.nl) }\end{array}$ \\
\hline Waterzuivering & CM_WATERZ & publicatie & Alterra Wageningen UR & De Knegt et al., in prep \\
\hline Natura 2000-gebieden & Natura2000_17feb2015_Export & 2015 & $\begin{array}{l}\text { Ministerie van EZ; Alterra Wageningen } \\
\text { UR }\end{array}$ & CBS etal., 2013 \\
\hline $\mathrm{CO} 2$ vastlegging & CM_KOOLST & publicatie & Alterra Wageningen UR & De Knegt et al., in prep \\
\hline Klimaatcorridor moeras & $\begin{array}{l}\text { 046k_moeras: } \\
\text { moerascorr_verbeteringen_jd }\end{array}$ & 2010 & PBL & Vonk et al., 2010 \\
\hline Klimaatcorridor heide & $\begin{array}{l}\text { 100k_bosheide: } \\
\text { heidecorr_verbeteringen_jd }\end{array}$ & 2010 & PBL & Vonk et al., 2010 \\
\hline Klimaatcorridor bos & $\begin{array}{l}\text { 100k_bosheide: } \\
\text { boscorr_verbeteringen_jd }\end{array}$ & 2010 & PBL & Vonk et al., 2010 \\
\hline Krimpgebieden & $\begin{array}{l}\text { Gemeenten_bridgis_2014shp:krim } \\
\text { pgebied }\end{array}$ & 2015 & Ministerie van Binnelandse Zaken & $\begin{array}{l}\text { https://www.rijksoverheid.nl/documenten/kaar } \\
\text { ten/2015/06/29/kaart-krimpgebieden-en- } \\
\text { anticipeergebieden-2015 }\end{array}$ \\
\hline Bodemvruchtbaarheid & Bodvruchtbaarheid_nieuw & publicatie & Alterra Wageningen UR & De Knegt et al., in prep \\
\hline Agr. grondprijs & $\begin{array}{l}\text { Gemeenten_bridgis_2014shp:gron } \\
\text { dprijs }\end{array}$ & 2015 & Kadaster, RVO, LEI & $\begin{array}{l}\text { http://asrvastgoedvermogensbeheer.nl/landelij } \\
\text { k-vastgoed/grondprijzen/bouwhoek-en- } \\
\text { hogeland }\end{array}$ \\
\hline Agr. grondprijs & $\begin{array}{l}\text { Gemeenten_bridgis_2014shp:gron } \\
\text { dprijs }\end{array}$ & 2015 & Kadaster, RVO, LEI & $\begin{array}{l}\text { http://asrvastgoedvermogensbeheer.nl/landelij } \\
\text { k-vastgoed/grondprijzen/bouwhoek-en- } \\
\text { hogeland }\end{array}$ \\
\hline bebouwing & LGN7 & 2012 & Alterra Wageningen UR & Hazeu et al., 2014 \\
\hline infrastructuur & LGN7 & 2012 & Alterra Wageningen UR & Hazeu et al., 2014 \\
\hline $\begin{array}{l}\text { Cultuurhistorische } \\
\text { Waardenkaart van Nederland }\end{array}$ & $\begin{array}{l}\text { Cultuurhistorische_combikaart } \\
\text { (zelf gedigitaliseerd) }\end{array}$ & 1999 & Verschillende ministeries & Nota Belvedere \\
\hline Kwetsbare natuur & $\begin{array}{l}\text { IMNAB20141014_Beheergebied_2 } \\
015\end{array}$ & 2014 & IPO, provincies & $\begin{array}{l}\text { https://www.portaalnatuurenlandschap. nl/the } \\
\text { mas/productencatalogus/kaarten/landelijke- } \\
\text { beheertypenkaart/ }\end{array}$ \\
\hline
\end{tabular}


Wageningen Environmental Research Postbus 47

6700 AA Wageningen

T 0317480700

www.wur.nl/environmental-research

Wageningen Environmental Research Rapport 2748

ISSN 1566-7197
De missie van Wageningen University \& Research is 'To explore the potential of nature to improve the quality of life'. Binnen Wageningen University \& Research bundelen Wageningen University en gespecialiseerde onderzoeksinstituten van Stichting Wageningen Research hun krachten om bij te dragen aan de oplossing van belangrijke vragen in het domein van gezonde voeding en leefomgeving. Met ongeveer 30 vestigingen, 5.000 medewerkers en 10.000 studenten behoort Wageningen University \& Research wereldwijd tot de aansprekende kennisinstellingen binnen haar domein. De integrale benadering van de vraagstukken en de samenwerking tussen verschillende disciplines vormen het hart van de unieke Wageningen aanpak. 



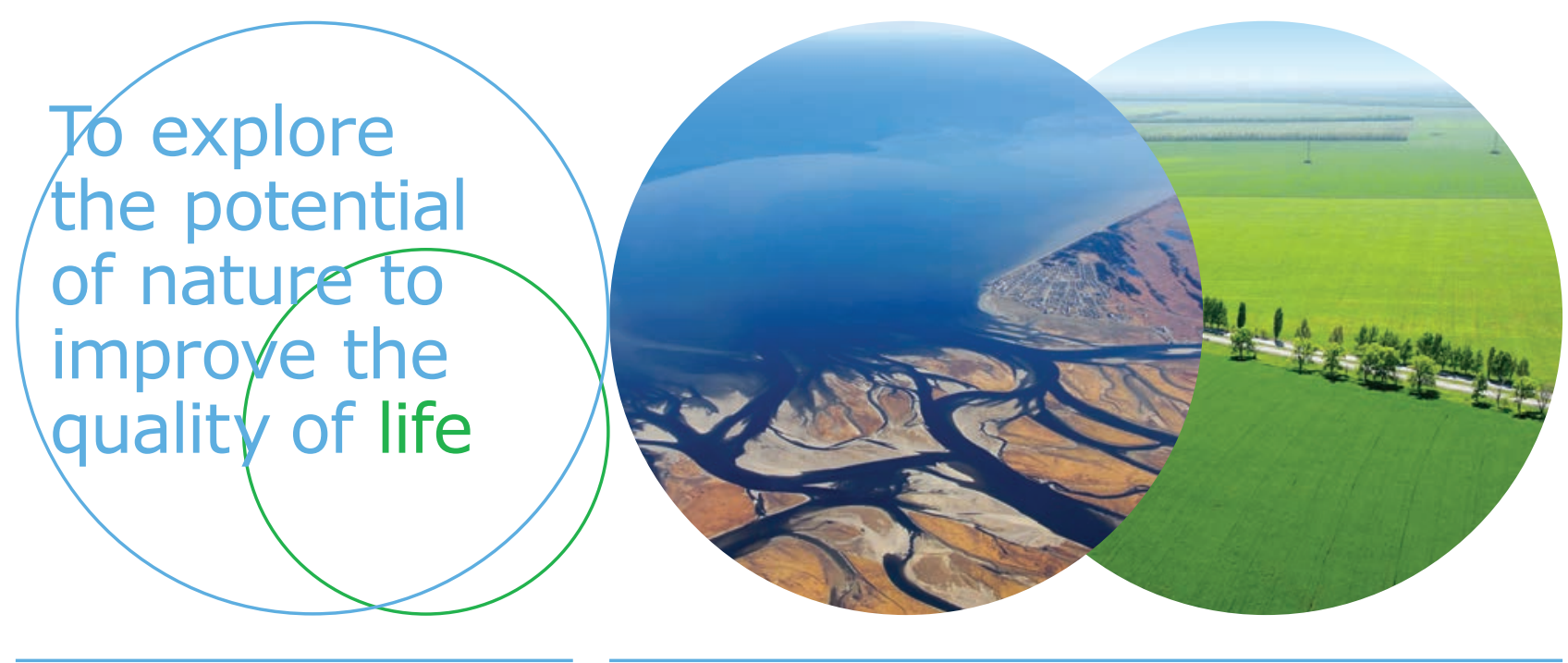

Wageningen Environmental Research Postbus 47

$6700 \mathrm{AB}$ Wageningen

T 317480700

www.wur.nl/environmental-research

Rapport 2748

ISSN 1566-7197
De missie van Wageningen University \& Research is 'To explore the potential of nature to improve the quality of life'. Binnen Wageningen University \& Research bundelen Wageningen University en gespecialiseerde onderzoeksinstituten van Stichting Wageningen Research hun krachten om bij te dragen aan de oplossing van belangrijke vragen in het domein van gezonde voeding en leefomgeving. Met ongeveer 30 vestigingen, 5.000 medewerkers en 10.000 studenten behoort Wageningen University \& Research wereldwijd tot de aansprekende kennisinstellingen binnen haar domein. De integrale benadering van de vraagstukken en de samenwerking tussen verschillende disciplines vormen het hart van de unieke Wageningen aanpak. 